\title{
SUSTAINABLE URBAN IMPLANTS
}

\author{
by
}

Meldan Kutertan

B. Arch. Tech. (Arch. Design Option), Ryerson University, Toronto, Ontario, 1998

\author{
A design thesis project \\ presented to Ryerson University \\ in partial fulfillment of the \\ requirements for the degree of \\ Master of Architecture
}

Toronto, Ontario, Canada, 2009

(C) Meldan Kutertan 
I hereby declare that I am the sole author of this thesis|project.

I authorize Ryerson University to lend this thesis|project to other institutions or individuals for the purpose of scholarly research.

I further authorize Ryerson University to reproduce this thesis|project by photocopying or by other means, in total or in part, at the request of other institutions or individuals for the purpose of scholarly research. 
Sustainable Urban Implants

Master of Architecture, 2009

Meldan Kutertan

Master of Architecture

Ryerson University, Toronto

\section{ABSTRACT}

"Sustainable Urban Implants" (SUIs) are sustainable urban cores based on principles of sustainable urban planning and sustainable architectural design practices that are melded together to achieve a most desirable sustainable living environment. As a combined force of urban planning, architecture and community interaction, this type of sustainable development is capable of changing fossil fuel-based city structures. It provides an alternative lifestyle that is enjoyable, economical, diverse and natural and that can enliven communities and strengthen social interaction.

Planting SUls on brownfields of Toronto suburbs, near public transportation nodes, is the strategy that has been identified as being effective and one that has been used in this thesis. As a result of this, private car-based commuting will decrease and public transportation will improve. An improvement of the lifestyle of suburbs will also be observed as current residents of the areas surrounding SUls will also benefit from the newly provided urban spaces and work places that create employment opportunities. 


\section{ACKNOWLEDGMENTS}

First of all, I would like to thank my wife and daughter who truly supported me in every way and practically became a part of my student life. I cannot be thankful enough for their patience as they waited a long time for me to finish my studies. I truly admire them. What they have done for me is priceless. Thank you, Sue. Thank you, Gemma.

My supervisor, Prof. Jurij Leshchyshyn, gave my thesis a fresh direction and showed me new paths to follow as I pursued my vision of sustainability. Without going through this experience and without his input, my thesis would not be this rich and meaningful. Thank you, Jurij.

To my program director, Professor Colin Ripley, for his most clear and precise critiques that helped me to look at architectural issues from a different perspective, my sincere thanks. Also, the constant support and efforts of program director, Professor John Cirka, will never be forgotten. He always found time for me even if it meant jeopardizing his own schedule and he helped me grow in knowledge and experience. Thank you, John.

To the Chair of the Department of Architectural Science, Dr. Kendra Schank Smith, I extend my gratitude for her great and inspiring comments that always made me feel good about my work and allowed me to enjoy it.

The helpful comments and advice of my external advisor, architect Mr. Ernest Tamburi, were always focused and on topic. His professionalism and his assistance in assessing my work priorities guided me onto the right path and saved me a tremendous amount of time. Thank you very much.

I also would like to thank all my Ryerson professors for their constant efforts to transfer their knowledge to me, to open my mind to new possibilities and to lead my vision in the right direction.

Dr. June Komisar, Architect

Professor Arthur Wigglesworth, Architect 
Dr. Al Smith, Architect

Professor Y.T. Leong, Architect

Professor Marsha Etkind

Ms. Cheryl Atkinson, Architect

Mr. John Ingrao, Architect

Professor Baruch Zone, Architect

Architect Mark Nawrocki demonstrated great understanding and support for me and my goals when I worked in his office. These studies would never have started and would not have been really possible without his initial support. Thank you, Mark. 


\section{DEDICATION}

I would like to dedicate my work to my wonderful daughter, Gemma. She has always been on the side of the weak and of the truth and, in a very professional way, never backed down when she felt she had found the right way to go or the right thing to do. She has always been an environmentalist in her way by protecting nature and caring for other human beings. She is there for the people she knows and for her friends when she finds they are in need of help.

I am certain that she has all the talents and skills needed to be a great leader. She has never put her responsibilities aside and has never failed to keep the promises she makes. I truly admire her and am very proud of her. I am particularly proud of her compassion towards humanity and of her clear vision of the future in which the next generations should live increasingly healthy and happy lives.

I hope that this work will inspire her and provide a solid foundation for her aspirations.

December, 2009 


\section{TABLE OF CONTENTS}

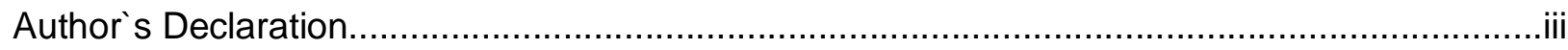

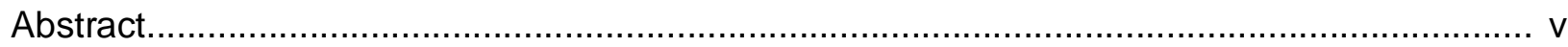

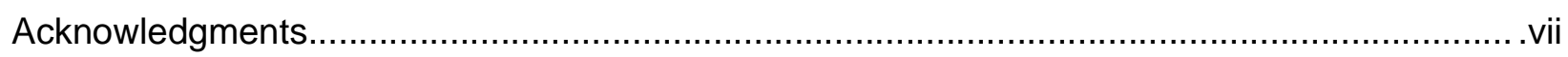

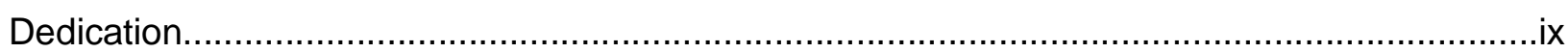

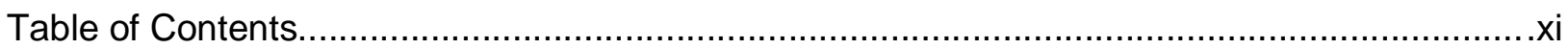

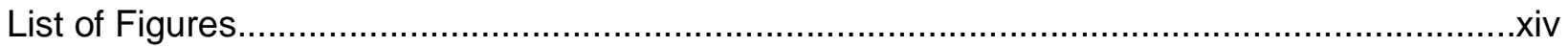

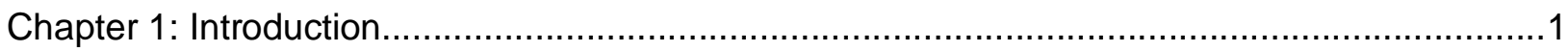

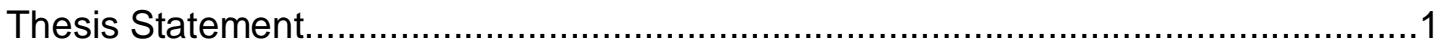

Chapter 2: Literature Review - Environment, architecture and urban planning..................... 2

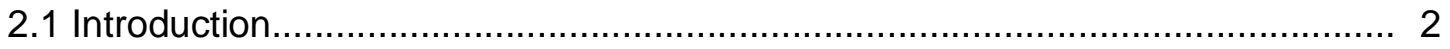

2.2 Relation of the building industry to the environment:................................... 3

2.2.1 Most used building material: Concrete and the environment.................. 5

2.3 Global energy trends and their affects on cities........................................... 7

2.4 Sustainability and Sustainable Communities................................................ 10

2.4.1 Sustainable communities......................................................... 11

2.4.2 Building blocks of sustainable communities.......................................... 11

2.4.3 Principles of sustainable communities....................................................12

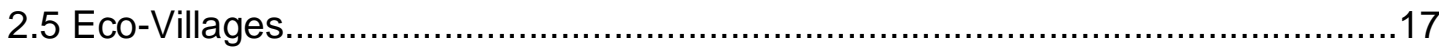

2.5.1 Key findings about eco-villages...................................................... 19

2.5.2 Common elements of eco-villages.................................................... 19

2.5.3 Varying elements of eco-villages.................................................... 19

2.5.4 Eco-Villages and general summary of the findings............................. 20

2.5.5 Case Study: Hjortshoj, near Aarhus, Denmark...................................21

2.6 Millennium Villages UK.................................................................... 24

2.6.1 Case Study: Allerton Bywater, UK.............................................29

2.6.2 Case Study: Sustainable community planning, Batawa, Ontario......... 31

2.6.3 Case Study: Greenwich Peninsula, London, UK............................... 33

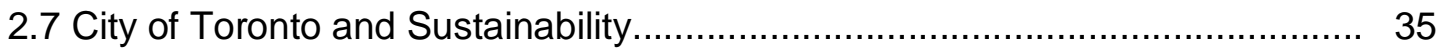


2.7.1 The transportation network of Toronto................................................. 38

2.8 Sustainable Development in Toronto..................................................... 42

2.8.1 Ontario government smart growth and urban design elements ............... 45

2.8.2 Public Spaces.......................................................................... 47

2.8.3 Existing Pedestrian Zones in Toronto................................................ 48

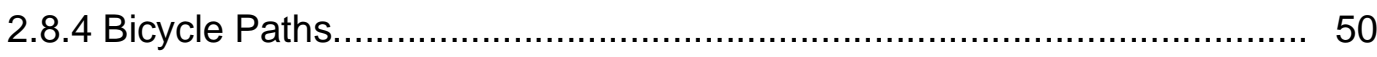

2.8.5 Zoning Requirements: Parking .................................................. 50

2.8.6 Neighbourhoods development and LEED........................................... 51

2.9 Sustainable developments on brownfields Toronto........................................ 53

2.9.1 Case Study: West Don Lands Toronto, Ontario...................................... 55

2.9.2 Case Study: 31 Broadcast Lane, Toronto Ontario.................................. 55

2.9.3 Case Study: Port Credit Village Mississauga (GTA), Ontario................... 56

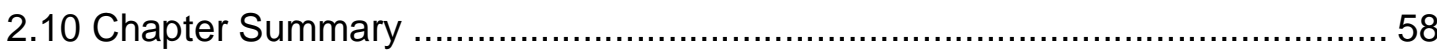

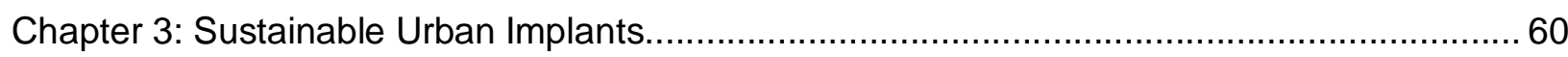

3.2.1 Where can sustainable urban implants be

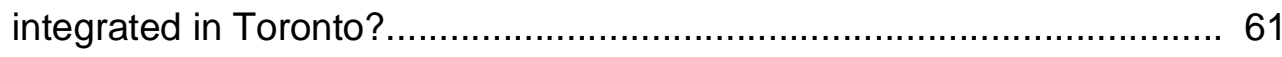

3.2.2 The influence of sustainable urban implants

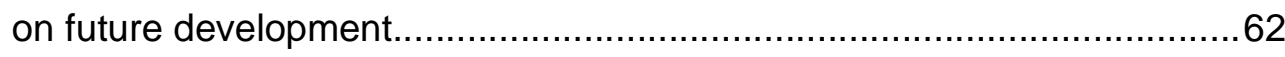

Chapter 4: The Demonstration project.............................................................................. 63

4.1 The chosen demonstration site and and demographics..................................63

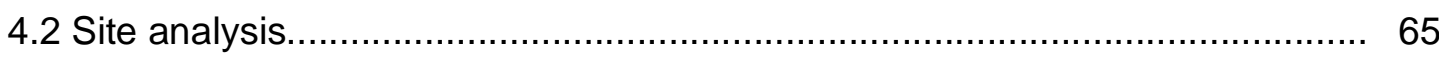

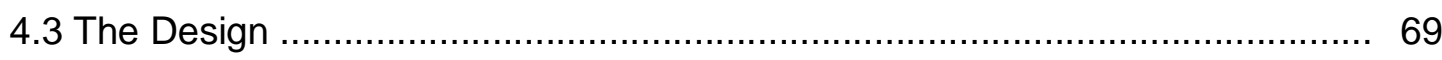

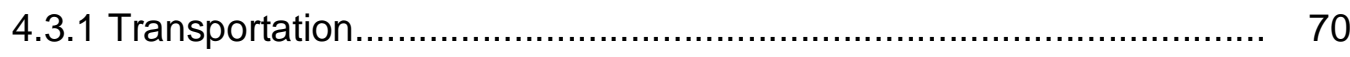

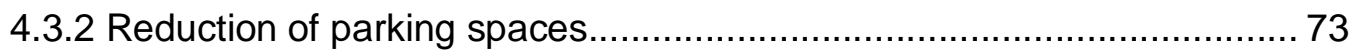

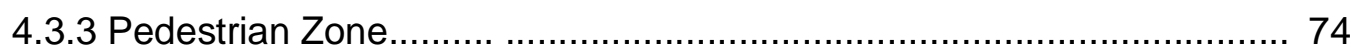

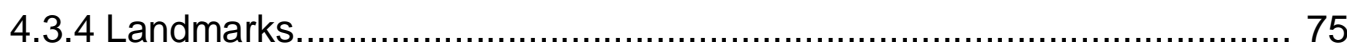

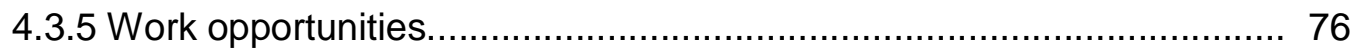

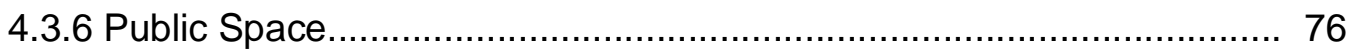

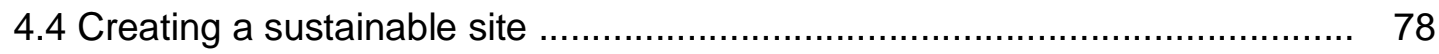

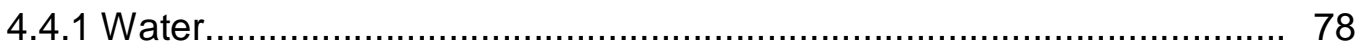

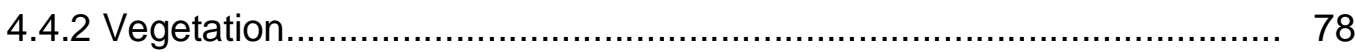




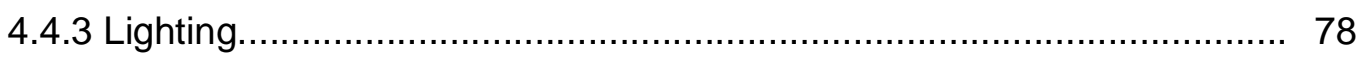

4.4.4 Buildings on the site and sustainable architecture............................. 79

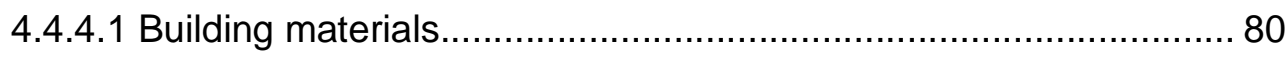

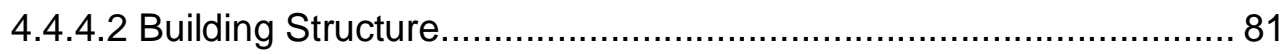

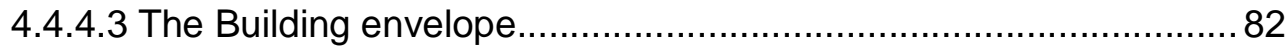

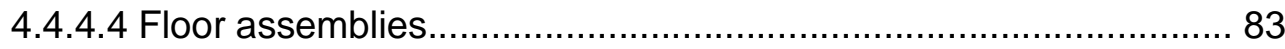

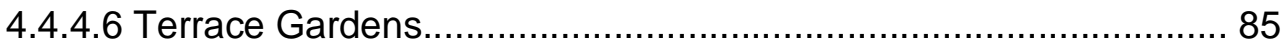

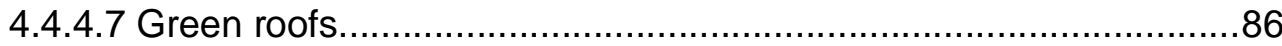

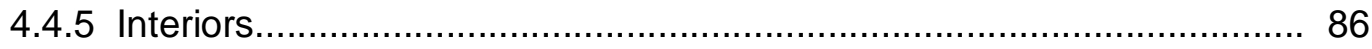

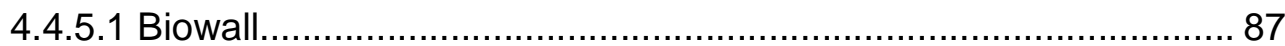

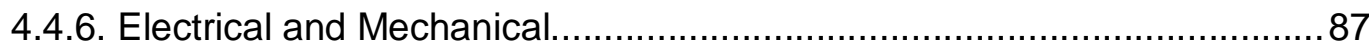

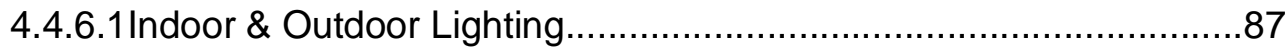

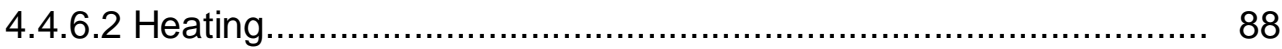

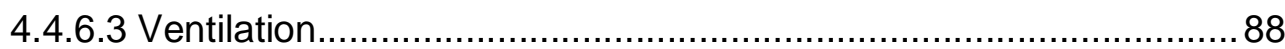

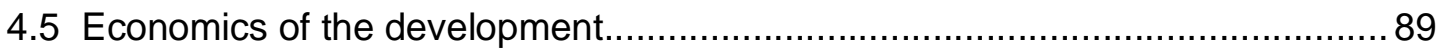

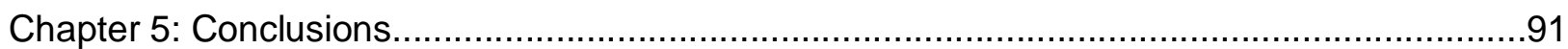




\section{LIST OF FIGURES}

Figure 2.1: Global Land and Ocean Temperature Anomaly (in $\left.{ }^{\circ} \mathrm{C}\right)$ Image credit: NASA

Figure 2.2: Canada's Greenhouse Gas Emissions produced by sector in 2008. Image credit: Ministry of transportation Canada.

Figure 2.3: GHG emissions level targeted by the Kyoto Protocol was missed by 29.1 \% in 2007. Image credit: Environment Canada

Figure 2.4: A look into a cement kiln in full operation. Image credit: LWB Refractories, Germany

Figure 2.5: Components of concrete mix. Image credit: Cement Association of Canada

Figure 2.6: Canada's GHGs estimates and forecast. Image credit:

Environment Canada

Figure 2.7: Portland cement production between 1995 - 2010. Image credit: EcoSmart Concrete

Figure 2.8: World energy consumption trends 1980-2030. Image credit: Energy information Administration

Figure 2.9: World electricity generations by fuel 2005-2030. Image credit: Energy information Administration

Figure 2.10: Increase of GHGs and decrease of GHG per GDP.Image credit:

Figure 2.11: The components of sustainability .Image credit: retrieved from the website http://www.euromoodle.org/ash/course/view.php?id=131

Figure 2.12: Diagram of the components of sustainable communities. Image credit: Urban Design Compendium 
Figure 2.13: A view from Hjortshoj Eco-Village Group 4 housing. Image credit: Arkitema Architects, Denmark

Figure 2.14: Another view from Hjortshoj Eco-Village. Image credit: Arkitema Architects, Denmark

Figure 2.15: A view from the development site. Image credit:

http://www.designformanufacture.info/allertonbywater

Figure 2.16: Development Plan of Allerton Bywater Millennium Village in the U.K. Image credit: http://www.designformanufacture.info/allertonbywater,

Figure 2.17: A view from A2 section development. Glazed sun rooms and open terraces are desirable architectural elements that provide transparency and social interaction. Image credit: http://www.designformanufacture.info/allertonbywater

Figure 2.18: A view above Batawa, Ontario. Image credit: http://batawa.ca/photos/custom/FTPFiles/TSW\%20Report.pdf

Figure 2.19: Sustainable Development Plan of Batawa, Ontario.: Image credit: http://batawa.ca/photos/custom/FTPFiles/TSW\%20Report.pdf

Figure 2.20: Sustainable Greenwich peninsula brownfield development beside Millennium Dome, London, U.K. Image credit: Greenwich Peninsula U.K.: http://www.greenwichpeninsula.co.uk/Content.aspx?urlkey=agp_md

Figure 2.21: A view from the inside of the grocery store of Greenwich peninsula brownfield development, London, U.K. Image credit: CABE London, U.K. http://www.cabe.org.uk/case-studies/sainsburys-supermarket-greenwichpeninsula?photos=true \&viewing $=3758$

Figure 2.22: Map of Immigration spread of the city Toronto. Image credit: Statistics Canada 
Figure 2.23: Canadian 2006 census data showing the population increase between 2001-2006. Image credit: Statistics Canada

Figure 2.24: Construction history map of the city Toronto. Image credit: Statistics Canda

Figure 2.25: Townhouses in Markham, Ontario. Image credit: Retrived from the website http://images.google.ca/imgres?imgurl=http://upload.wikimedia.org/wikipedia/commo ns/thumb/1/14/Markham-suburbs.id.jpg.jpg/400px-Markhamsuburbs.id.jpg.jpg\&imgrefurl=http://en.wikipedia.org/wiki/Markham,_Ontario\&usg= KfnsC2m1VSVGqH6UZi4JgAS8okg=\&h=298\&w=400\&sZ=56\&hl=en\&start=13\&um= 1\&tbnid=AtBalKnihLR0EM:\&tbnh=92\&tbnw=124\&prev=/images\%3Fq\%3Dmarkham \%2Bontario\%26hl\%3Den\%26rlz\%3D1T4ADFA_enCA357CA357\%26um\%3D1

Figure 2.26: In 1946 planed rapid transit light railway lines of Toronto. Image credit: Mark Osbaldeston (2008). Unbuilt Toronto: Toronto, Canada: Dundurn Press

Figure 2.27: Subway lines of Toronto. Similar to 1946 Toronto`s planed rapid transit lines. No significant improvement. Image credit: Toronto Transit Commission

Figure 2.28: The share of transportation medium in trips made within Toronto GTA. Image credit: Ministry of Transportation Ontario

Figure 2.29: Early established railway networks in Ontario. Image credit. City of Toronto

Figure 2.30: Old city Toronto. Image credit: City of Toronto

Figure 2.30: Toronto Waterfront today : Globizen

Figure 2.31: Smart Growth components. Image credit: Equinox. Centre

Figure 2.32: An imaginative view of an urban space. Image credit: Meldan Kutertan

Figure 2.33: The city hall and urban space Bonn, Germany. Image credit: DW-WORLD.DE, Deutsche Welle 
Figure 2.34: A car-free pedestrian zone in the High Street, Cologne, Germany. Image credit: Dierk's Page http://www.anicursor.com/koeln_7733.jpg

Figure 2.35: Distillery District Toronto. Image credit: Guelph Civic League

Figure 2.36: Now a pedestrian zone: Times Square in New York City, NY, USA. Image credit: Oyster Hotel Reviews

Figure 2.37: A common picture: Bicycle riders in Copenhagen, Denmark. Image credit: www.News.cn / www.chinaview.cn

Figure 2.38: Overall development plan. West Donlands Project shown with other parts of the Toronto Waterfront Projects. Image credit: Toronto Waterfront

Figure 2.39: Overall development plan West Don Lands. Image credit: Building. www.building.ca

Figure 2.40: An imaginative view towards west from the new development West Don Lands, Toronto, ON.: Image credit: Dierk's Page http://www.anicursor.com/koeln_7733.jpg

Figure 2.41: A view of Broadcast Lane development. Image credit: TO Built

Figure 2.42: Location of the site. Image credit. Google Map, Meldan Kutertan

Figure 2.43: A phasing plan of the Port Credit Village project, Mississauga, Ontario. Image credit: www.News.cn / www.chinaview.cn

Figure 2. 44: A View from the development. Image credit: Urban Land Institute

Figure 3.1: The map shows possible Sustainable Urban Implant developments along the subway lines on brownfields. Image credit: Google map, Meldan Kutertan 
Figure 4.1: Chosen location for Sustainable Urban Implant demonstration. Image credit: Meldan Kutertan

Figure 4.2: Pie charts showing still a large number of people travel with cars. Image credit: City of Toronto

Figure 4.3: Income distribution of Scarborough vs. Toronto. Image credit: City of Toronto

Figure 4.4: General site plan. Image credit: Google Map, Meldan Kutertan

Figure 4.5: A view towards the TTC buildings. Image credit Meldan Kutertan

Figure 4.6: A 180ํvำ from St Clair Avenue East (on the left) towards the chosen site. Image credit: Meldan Kutertan

Figure 4.7: A $180^{\circ}$ view of the north side of the chosen site. Image credit: Meldan Kutertan

Figure 4.8: New townhouse development on the north side of the chosen site. Image credit: Meldan Kutertan

Figure 4.9: Pedestrian under passageway to TTC building. Image credit: Meldan Kutertan

Figure 4.10: A view from the chosen site towards new housing developments along Warden Avenue. Image credit: Meldan Kutertan

Figure 4.11: An early development sketch of the site. Image credit: Meldan Kutertan

Figure 4.12: A sketch showing major transportation routes separating residential areas. Image credit: Meldan Kutertan

Figure 4.13: General site plan showing walking distances and redesigned roads. Image credit: Meldan Kutertan

Figure 4.13: Proposed site. Image credit: Meldan Kutertan 
Figure 4.14: A View of the developed site from the southwest; Image credit: Meldan Kutertan

Figure 4.15 North-south section through the site showing underground parking and buildings. Image credit: Meldan Kutertan

Figure 4.16 A view towards shopping street of the development and grocery shop. Image credit: Meldan Kutertan

Figure 4.17: A view towards the library complex. Image credit: Meldan Kutertan

Figure 4.18: Public space at the northwest corner of the site and extending shopping street. Image credit: Meldan Kutertan

Figure 4.19: A view from the east towards the library building. Image credit: Meldan Kutertan

Figure 4.20: Demonstration building. Image credit: Meldan Kutertan

Figure 4.21: Northeast glazed facade of the demonstration building with recycled wood inserts. Provoltaic panels on top will provide renewable energy. Image credit: Meldan Kutertan

Figure 4.22: The elevation shows the moveable vertical wooden panels against the west sun. Image credit: Meldan Kutertan

Figure 4.23: The southeast facade provides more glazed area, since the morning sun is cooler than the afternoon sun. Image credit: Meldan Kutertan

Figure 4.24: The building facade exhibits recycled brick, recycled glass and terrace gardens with sunshades and overhangs. Image credit: Meldan Kutertan

Figure 4.25: TJI joists also called Engineered Wooden I-Beams. Image credit: www.Sishomes.com 
Figure 4.26: Hydronic flex tubes laid out on floor assembly and heat reflectors. Image credit: Eco Depot USA

Figure 4.27: A typical terrace garden. Image credit: Energy and Environment.com http://www.energyandenvironment.com/media/greenRoofing-1.jpg

Figure 4.28: A typical floor plan with terrace garden. Image credit: Meldan Kutertan

Figure 4.29: A typical green roof assembly. Image credit: Flickr from Yahoo

Figure 4.30: A view of a typical biowall. Image credit: The Geraldine R. Doge Blog Foundation

Figure 4.31: A section showing natural ventilation. Image credit: Meldan Kutertan 


\section{INTRODUCTION}

In the last decade ecological problems have become of paramount importance. Our mostly fossil fuel-based energy system (oil and coal) has been the major cause of environmental problems such as global warming. Burning fossil fuels and quarrying materials and transporting them are some of the major causes of these negative effects on the environment such as the greenhouse effect. Environmental research has also made clear that architectural designs and materials can affect total energy consumption of buildings, both in their construction and over their lifespans, and reduce the use of fossil fuel-based energy.

However, buildings can only save so much energy and as long as fossil fuel-based transportation exists, the effect on the environment of building design and construction itself will have limited impact on the environmental big picture. To introduce counter-measures to address environmental problems and to achieve true sustainability, in addition to constructing sustainable energy-efficient buildings, oil-based transportation must be reduced and, ideally, eliminated. This will only be possible by reducing distances between destinations; therefore, initial architectural designs must incorporate urban planning to this end.

\subsection{Thesis Statement}

True sustainability can only be achieved through the holistic integration of sustainable architecture and sustainable urban planning. 


\section{ENVIRONMENT, ARCHITECTURE AND URBAN PLANNING}

\section{The relation of environmental issues to architecture and urban planning}

\subsection{Introduction}

To understand the relation of architecture to environmental issues it is important to identify the causes and sources of environmental problems. Over recent years, scientists have concluded, from weather observations and measurements, that average surface temperatures around the globe are gradually rising; this phenomenon is called "global warming". In accordance with the information given by NASA (Retrieved from the website http://www.nasa.gov/worldbook/global_warming_worldbook.html)

"Global warming is an increase in the average temperature of the Earth's surface. Since the late 1800 's, the average global temperature has increased from 0.7 to 1.4 degrees $F\left(0.4\right.$ to $0.8^{\circ} \mathrm{C}$ ). Many experts estimate that the average temperature will rise an additional 2.5 to 10.4 degrees $\mathrm{F}$ $\left(1.4\right.$ to $5.8^{\circ} \mathrm{C}$ ) by 2100 . That rate of increase would be much larger than most past rates of increase" (Retrieved from the website http://www.nasa.gov/worldbook/global_warming_worldbook.html , December 2009)

Global Land-Ocean Temperature Anomaly $\left({ }^{\circ} \mathrm{C}\right)$

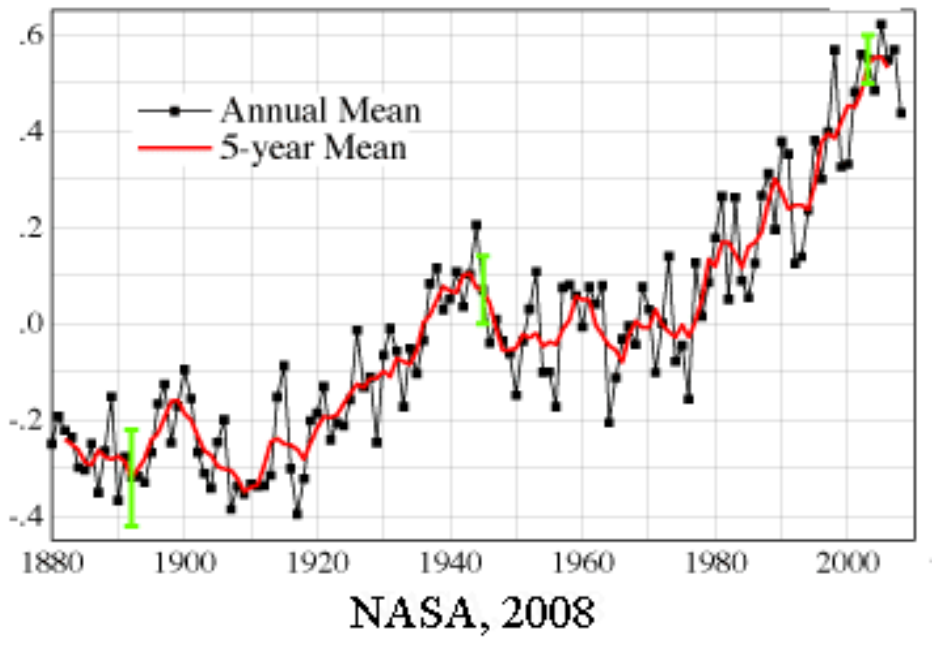

The scientific consensus is that the Earth's average temperature is rising due to industrial interference with the natural environment. In particular, gas emissions (largely composed of carbon dioxide) from manufacturing and fossil-fuel based transportation systems are producing a "greenhouse effect": the sun's heat is trapped here on Earth.

Figure 2.1: Global Land and Ocean Temperature Anomaly (in ${ }^{\circ} \mathrm{C}$ )

By interacting with the environment in such negative ways, humans are affecting the balance of nature. Animal and plant habitats are being degraded or destroyed and surviving species are forced to attempt to adapt to new, and in many cases, non-viable conditions. 


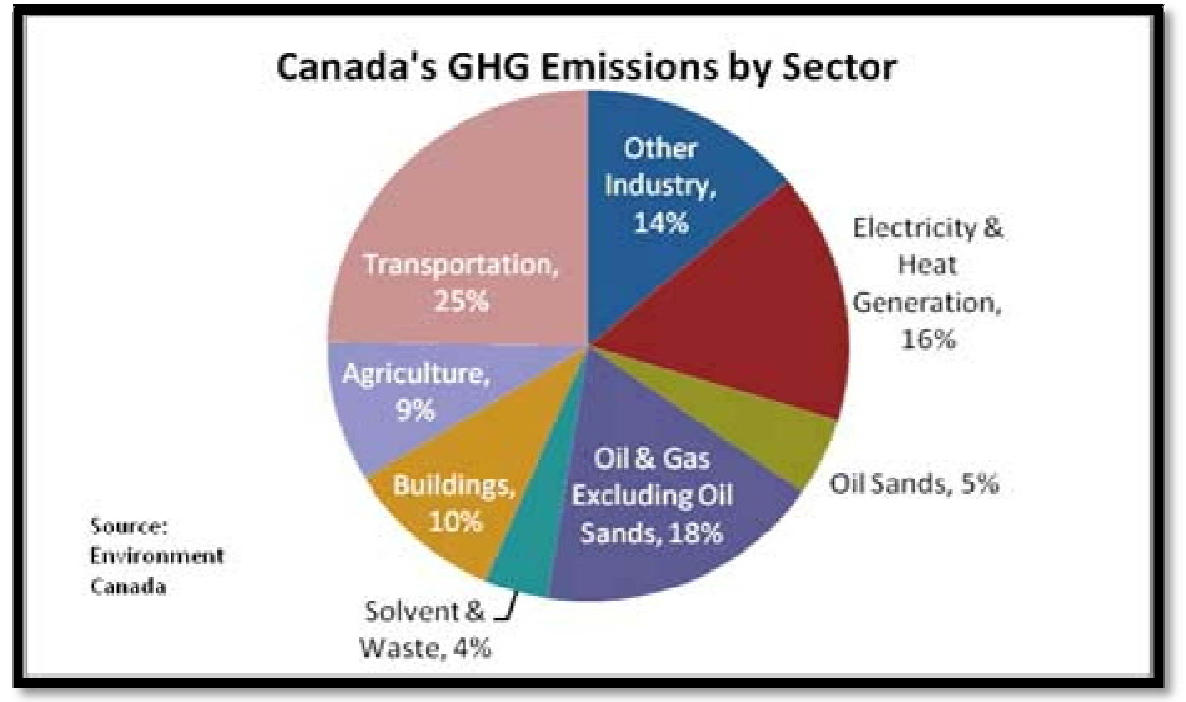

Figure 2.2: Canada's Greenhouse Gas Emissions produced by sector in 2008
The energy sector

is a major producer of greenhouse gases (GHGs) (See Figure 2.2). Fossil fuels are used to generate heating and cooling, and to keep vehicles and machinery running. Electric energy is gained mainly from burning fossil fuels such as coal and is used in industry (for manufacturing, for instance.) All industries produce some GHG emissions since the fossil fuels they use contain carbon. The fact that these emissions are unavoidable is internationally acknowledged and has led to the establishment of treaties such as the UNFCC (United Nations Framework Convention on Climate Change) and to protocols such as the 2005 Kyoto Protocol.

\subsection{Relation of the building industry to environment}

The building industry is another major contributor to global warming. In a February, 2006 article in Green Source: the Magazine of Sustainable Design, Deborah Snoonian interviewed Edward Mazria of the American Institute of Architects (AIA). He launched a "challenge derby" for carbon-free architecture to go until 2030 that has attracted the Royal Architectural Institute of Canada (RAIC) and other architectural organizations. 
Mazaria's research concluded that the construction industry generates half the existing greenhouse emissions. He views construction as an economic sector and is of the opinion that architects determine and control the quality, materials and energy patterns of buildings and therefore can influence the construction industry itself and the producers of building materials. He calculated the embodied energy of buildings that contribute directly to global warming and also the amount of energy needed to run household equipment and mechanical heating and lighting systems that contribute indirectly. (The production of electricity derives its energy from fossil-fuel burning energy plants that produce $\mathrm{CO}_{2}$.)

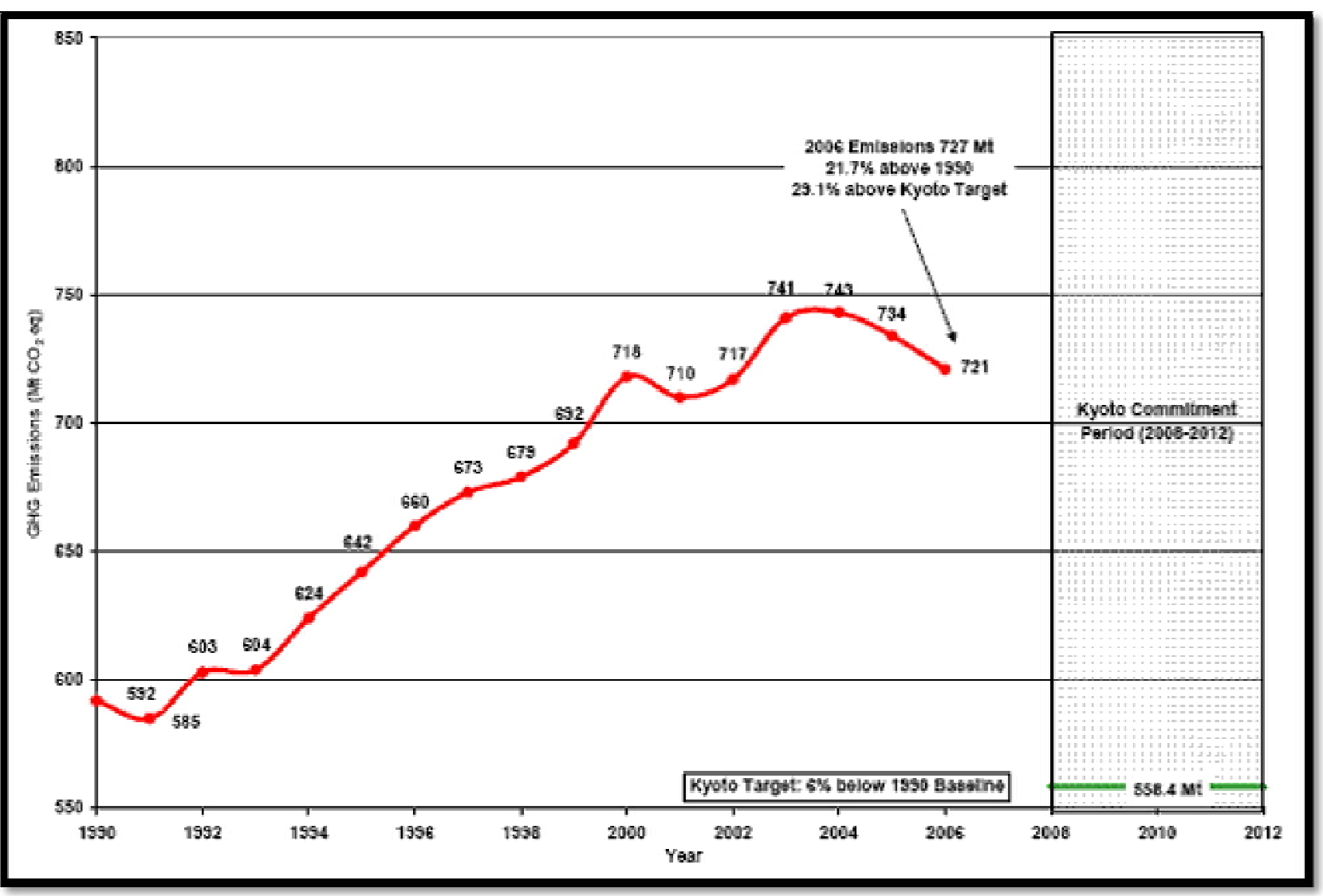

Figure 2.3: GHG emissions level targeted by the Kyoto Protocol was missed by $29.1 \%$ in 2007. 


\subsubsection{Most used building material: Concrete and the environment}

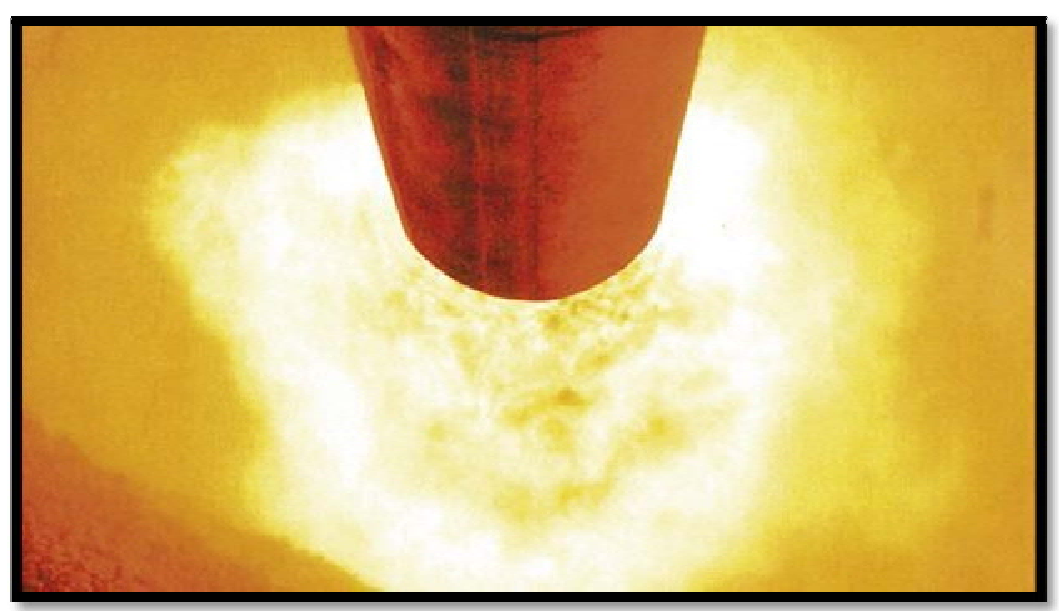

Figure 2.4: A look into a cement kiln in full operation
One of the most widely used building materials is concrete; it is valued for its strength, flexibility, adaptability and availability worldwide. To make concrete, aggregates such as gravel and sand are mixed with water and air. The bonding glue for these aggregates is cement, manufactured from a limestone base. In manufacturing cement, a tremendous amount of fossil fuel energy is used. A cement kiln must be heated to approximately $1400-1500$ degrees Celsius, using natural gas, to melt the limestone base.

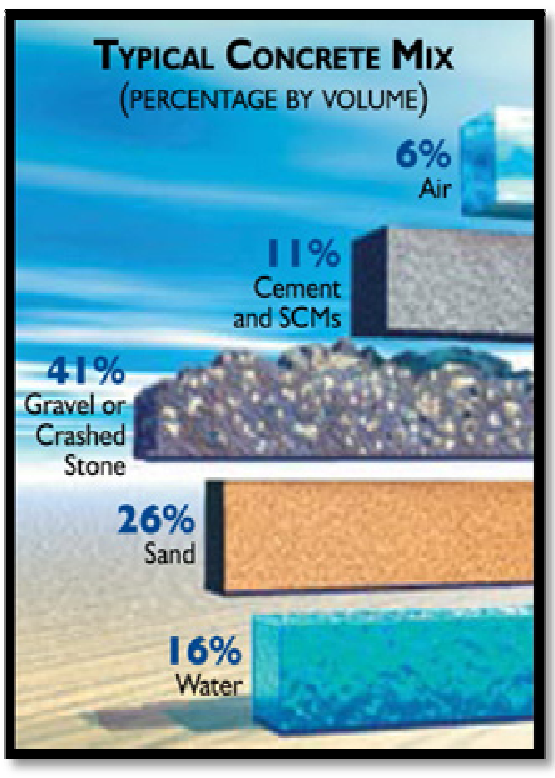

Figure 2.5: Components of concrete mix
(Retrieved from the website http://www.understandingcement.com/kiln.html, December 2009) In the resulting chemical reaction, limestone emits $\mathrm{CO}_{2}$ at very high temperatures. The immense heat turns limestone (its chemical description is calcium carbonate $\mathrm{CaCO} 3$ ) into cement clinker (calcium oxide $\mathrm{CaCO})$.

(Retrieved from the website

http://www.psl.bc.ca/equipment/cement/, November 2009).

As concrete is so versatile and limestone, for cement production, is so common and manufacturing cement involves an easier process than other building materials such as steel, aluminum and glass, concrete is the most widely used building material in the world. At the same time, it is the number one $\mathrm{CO}_{2}$ source in the building industry. 


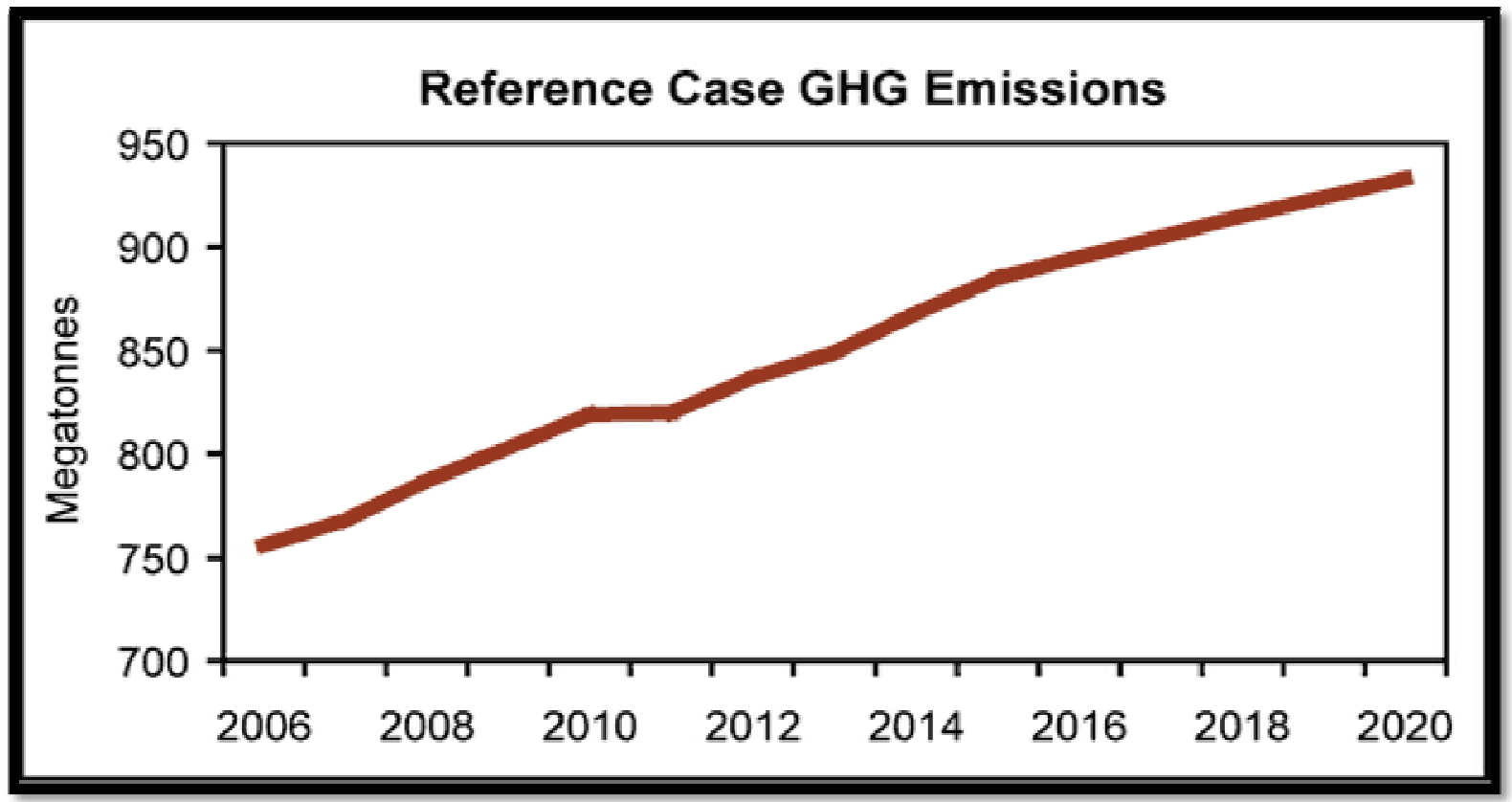

Figure 2.6: Canada's GHGs estimates and forecast

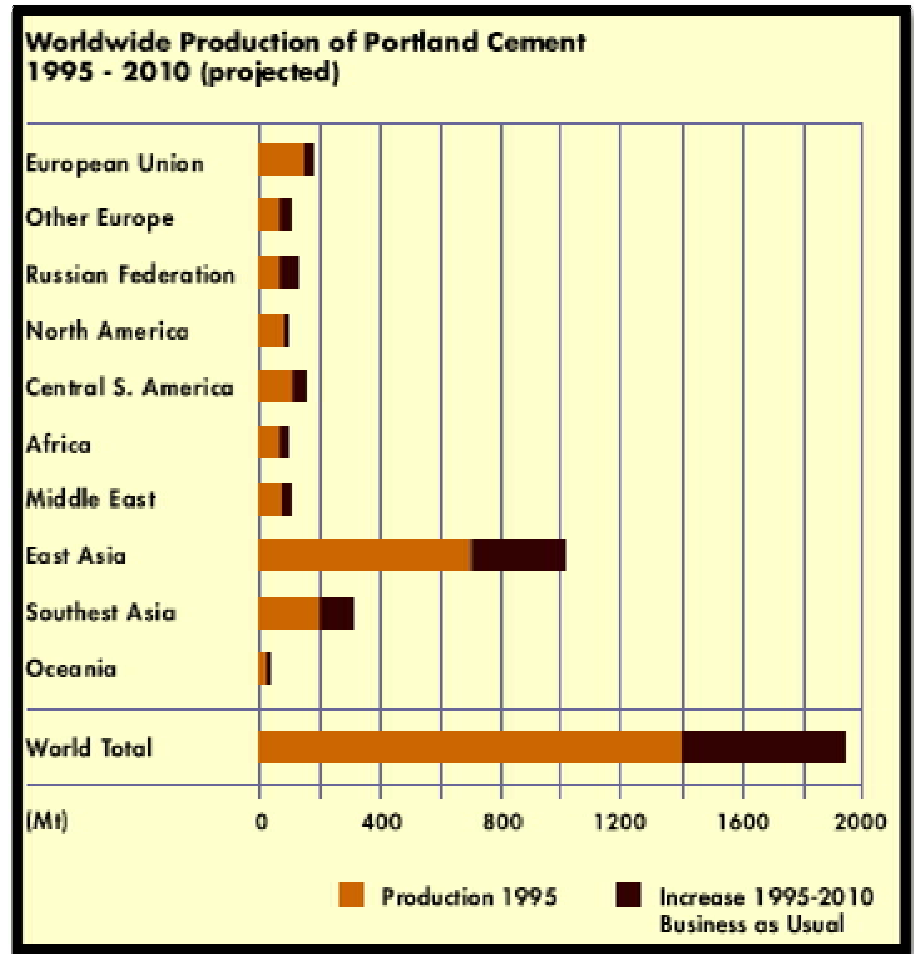

Figure 2.7: Portland cement production between 1995 2010
The cement industry is working hard to reduce its $\mathrm{GHG}$ emissions. In Canada, the last report of the Cement Association of Canada makes note of recent achievements in gas emissions reductions. These have been achieved particularly in developed countries with the economic power to invest in more efficient technologies. It would be expected, in light of these investments, that $\mathrm{GHG}$ emissions would be decreasing. However, this is not the case. They are increasing because of the world population growth and increasing demand of goods and transportation of these goods. 
Figure 9. World Marketed Energy Consumption, 1980-2030

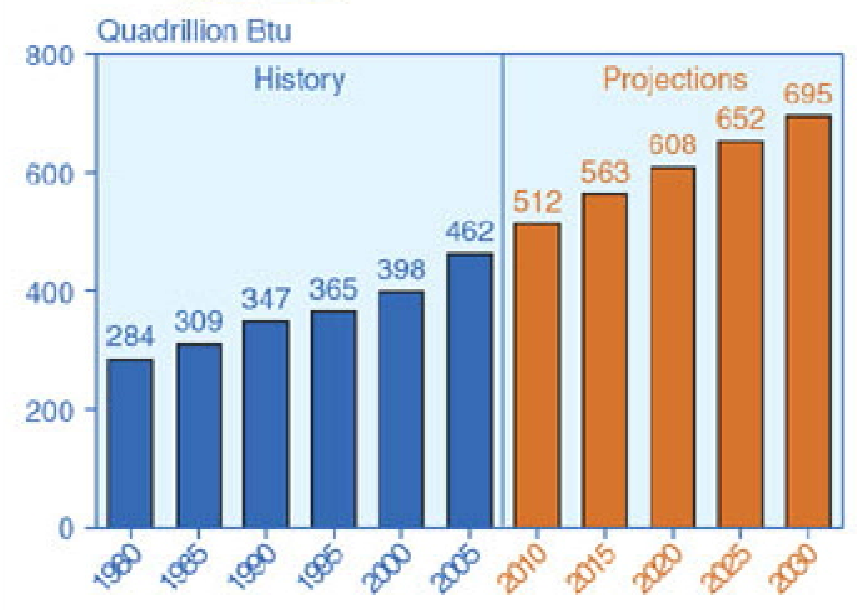

Sources: History: Energy Information Administration (EIA), International Energy Annual 2005 (June-October 2007), web site www.eia.doe,gov/lea. Projections: ElA, World Energy Projections Plus (2008).

Figure 2.8: World energy consumption trends 1980-2030
The worldwide demand for concrete has increased and this trend is expected to continue, with consumption of concrete increasing still further as new global economies evolve. As emerging markets such as China, Russia, the Eastern European countries and India enter the global economy, and the world's population continues to increase, the need for construction will grow, creating a worldwide need for more buildings, infrastructure and lifecycle maintenance. Data shows that the construction industry is expanding to meet the demand for buildings of various types, especially residential. Of course,

concrete is just one of the main building materials. Steel, aluminum and other building materials also contribute to $\mathrm{CO}_{2}$ emission, since fossil fuels are directly or indirectly involved in their manufacturing. The effort to satisfy the increased demand for building materials like cement will result in an increase in total worldwide energy consumption and in the quantity of $\mathrm{CO}_{2}$ emissions. (Retrieved from the website http://www.ecosmartconcrete.com/enviro cement.cfm, April 2009)

\subsection{Global energy trends and their affects on cities}

It is clear that energy consumption in the world market is increasing and will continue to increase. (See Figure 2.8.) Based on world population growth, it is expected that this demand will be approximately $50 \%$ greater in 2030 than it is now. (Retrieved from the website www. Eia.doe.gov, April 2009). According to this report, energy consumed by non- member countries of the Organisation for Economic Co-Operation and Development will surpass that of member countries by a great margin. Carbon-based fuel consumption will likely increase gradually between now and 2030. China will consume more coal and produce more cement than any other country. 
China and the United Arab Emirates are just two of the countries creating modern cities with high-rise buildings. The immense construction sites in these regions and around the world use a great deal of concrete, steel, and other construction materials. Industries are trying to reduce the greenhouse gas emissions but at the same time the demand for construction materials, especially cement, pushes these industries to produce even more materials.

\section{Developing countries need} roads, concrete pavements, buildings and underground infrastructure. The developed countries need to maintain their status and accommodate the growing needs of their populations as well. All that building requires energy.

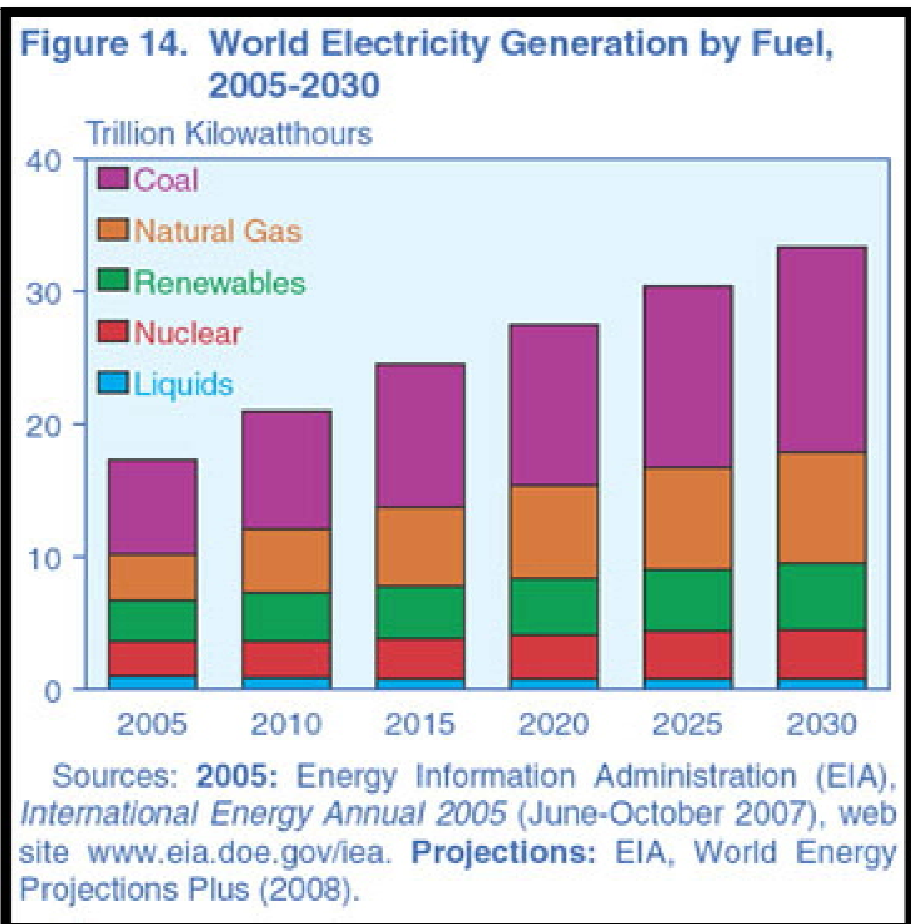

Figure 2.9: World electricity generations by fuel 2005-2030

As the world's population increases, so do demands on energy for building and transportation needs. Therefore, greenhouse gas emissions are increasing instead of dropping, even though the industries are becoming increasingly more energy efficient by introducing new environmentally friendly technologies.

The transportation of building materials and the operation of construction machinery (both using fossil fuels) contribute to $\mathrm{CO}_{2}$ emissions. 


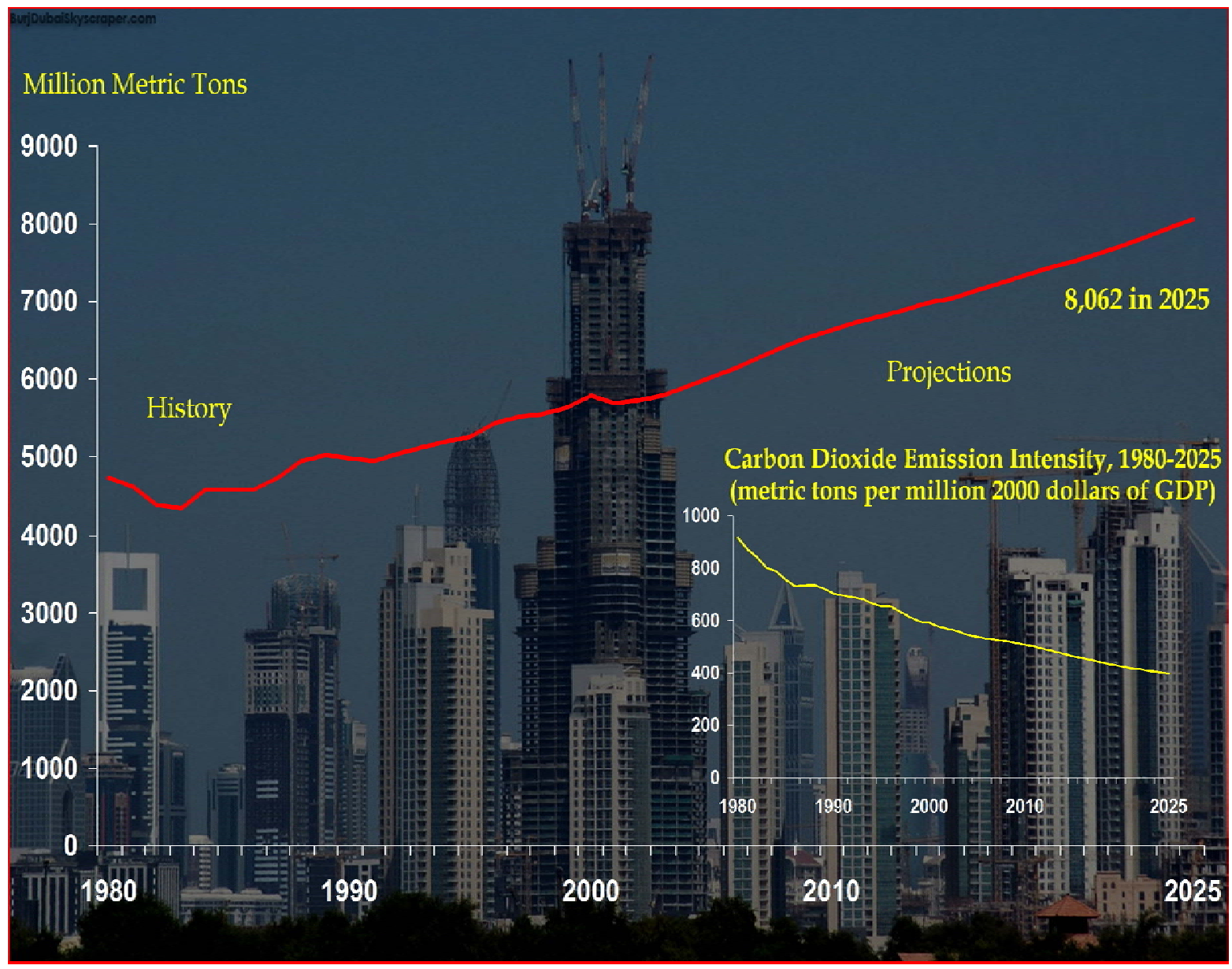

Figure 2.10: Increase of GHGs and decrease of GHG per GDP

Of course, cities with their agglomerations of buildings and populations have a huge impact on the environment. The necessity of transporting goods into and out of them alone demands a lot of energy. The built environment arising from urban planning and the lifestyles of residents are also determining factors in energy efficiency. Based on the technological advances in developed countries the energy efficiency of houses and transportation and emission control mechanism of transportation and industry is increasingly being more energy efficient and GHG emissions are decreasing per capita (GDP) See Fig. 2.10. But again the figure also confirms that globally GHGs are increasing.

To produce, to construct, to build, to transport, and to maintain our lifestyles in the future will require energy and resources. Unfortunately, the production of goods through current fossilfuel based energy resources endangers the Earth's ecological system as GHGs are pumped into the atmosphere. The consumption of Earth's finite, fossil fuel-based energy resources 
endangers future generations. Eventually, these energy sources will be depleted and everything dependent on this energy system will collapse. We must cut down on our energy consumption and find ways to make our current energy system better, healthier and more environmentally friendly. Efforts made towards sustainability, such as SUIs and development of alternate energy sources will help provide a better lifestyle for future generations. Sustainability is defined by the World Commission on Environment and Development as "forms of progress that meet the needs of the present without compromising the ability of future generations to meet their needs." (Retrieved from the website http://www.griffith.edu.au/ofm/sustainability/content_definition.html). Let us look at this a bit more closely.

\subsection{Sustainability}

\section{The Three Spheres of Sustainability}

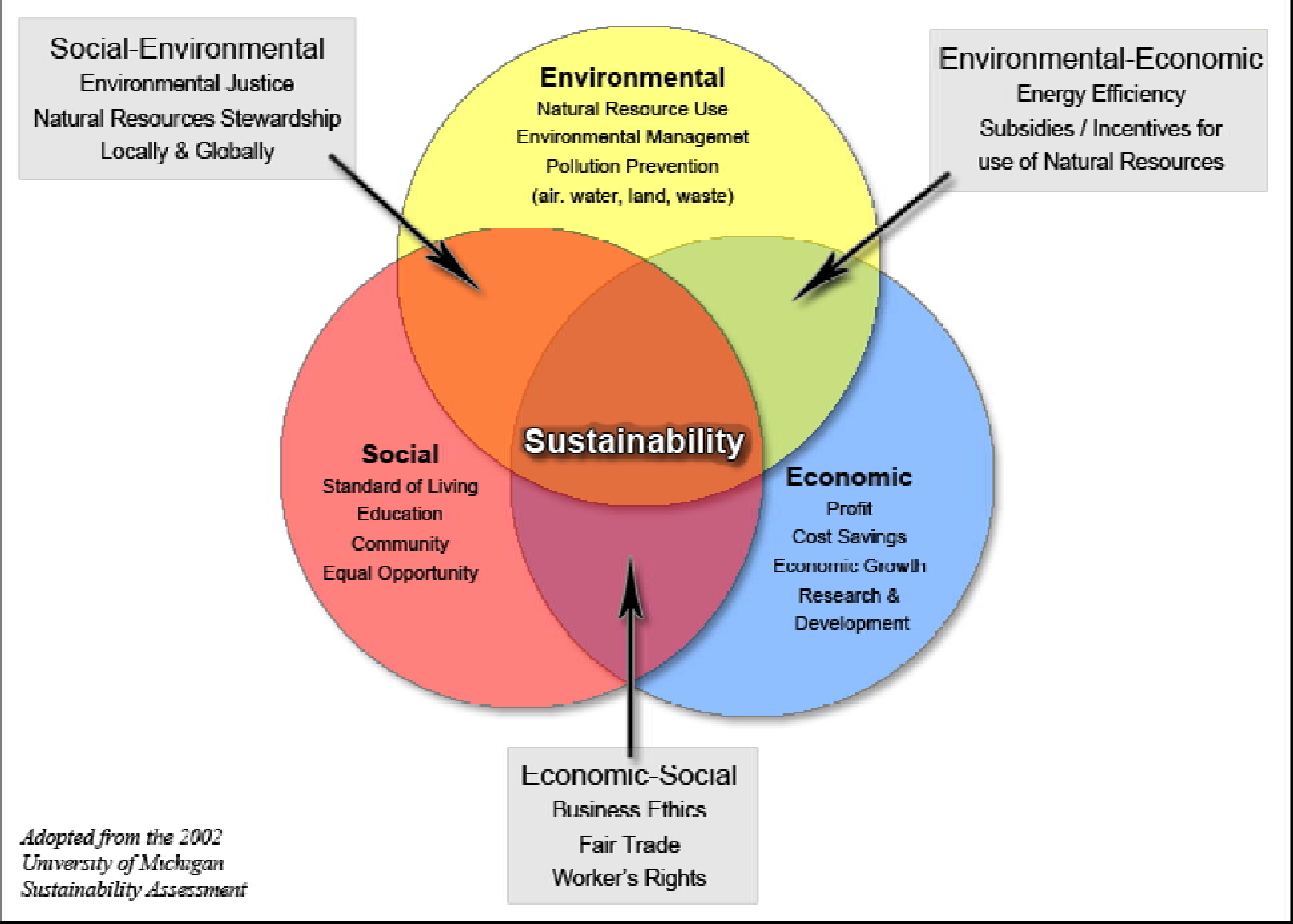

Figure 2.11: The components of sustainablilty 
Sustainability involves an interaction of social, economic and environmental issues. Sustainability for the future is dependent on reducing our consumption of Earth's natural resources, on being energy efficient and on adapting our cities to a better and more sustainable fossil-fuel free system and lifestyle. As architects we cannot affect the energy sector directly. But we can design energy-efficient buildings, use recycled materials and natural renewable energy sources to cut down on fossil fuel use, and also encourage the use of public transportation systems as an alternative to car-dependent lifestyles.

Around the world there are many examples of successful alternative communities and villages that were developed by people who took environmental issues and sustainability very seriously. These are more developed particularly in Europe since Europeans tend to be more sensitive to environmental issues and also more politically active.

\subsubsection{Sustainable communities}

In December, 2005 the Rt. Honourable John Prescott, Deputy Prime Minister of the U.K., invited E.U. ministers and representatives to Bristol to discuss approaches for sustainable communities such as those found throughout Europe in cities such as Berlin, Barcelona and at home in Birmingham. The purpose of this gathering was to determine the benefits of such communities, and also to discuss their framework and common characteristics in order to set out guidelines for similar ventures around the world. The outcomes of the meeting became known as the Bristol Accord. (Office of the Deputy Prime Minister, London. March 2006, U.K. Presidency EU Ministerial Informal on Sustainable Communities Policy Papers, Page 5)

\subsubsection{Building blocks of sustainable communities}

The most widely accepted definition of sustainable communities is:

"Sustainable communities are places where people want to live and work, now and in the future" (UK Bristol Accord Policy papers, 2006).

Sustainable communities should meet the needs of future as well as existing residents. They are environmentally sensitive and offer high-quality lifestyles because they are well planned and safe, and provide equal living and working opportunities for all residents. Their key principles, as set out by the European informal committee Bristol Accord, include: economic growth, social inclusion and justice (including response to the challenge of social integration), 
the role of cities, sustainable development, and the ability to exist at the regional, city, local and neighbourhood levels.

Without economic growth, countries will be unable to invest in the development and maintenance of sustainable communities. Such communities must also develop out of social equity and justice. Cities are a key factor in their success: vibrant cities with strong cultural identities tend to produce successful sustainable communities. The balancing of social, economic and environmental issues, keeping in mind the needs of future generations, is important to sustainability.

Sustainable communities reflect the circumstances and conditions of their locations and so no specific design can be assigned generally to all of them. While they will all be different in appearance, they will all reflect the following characteristics as set out by the Bristol Accord committee:

\subsubsection{Principles of sustainable communities}

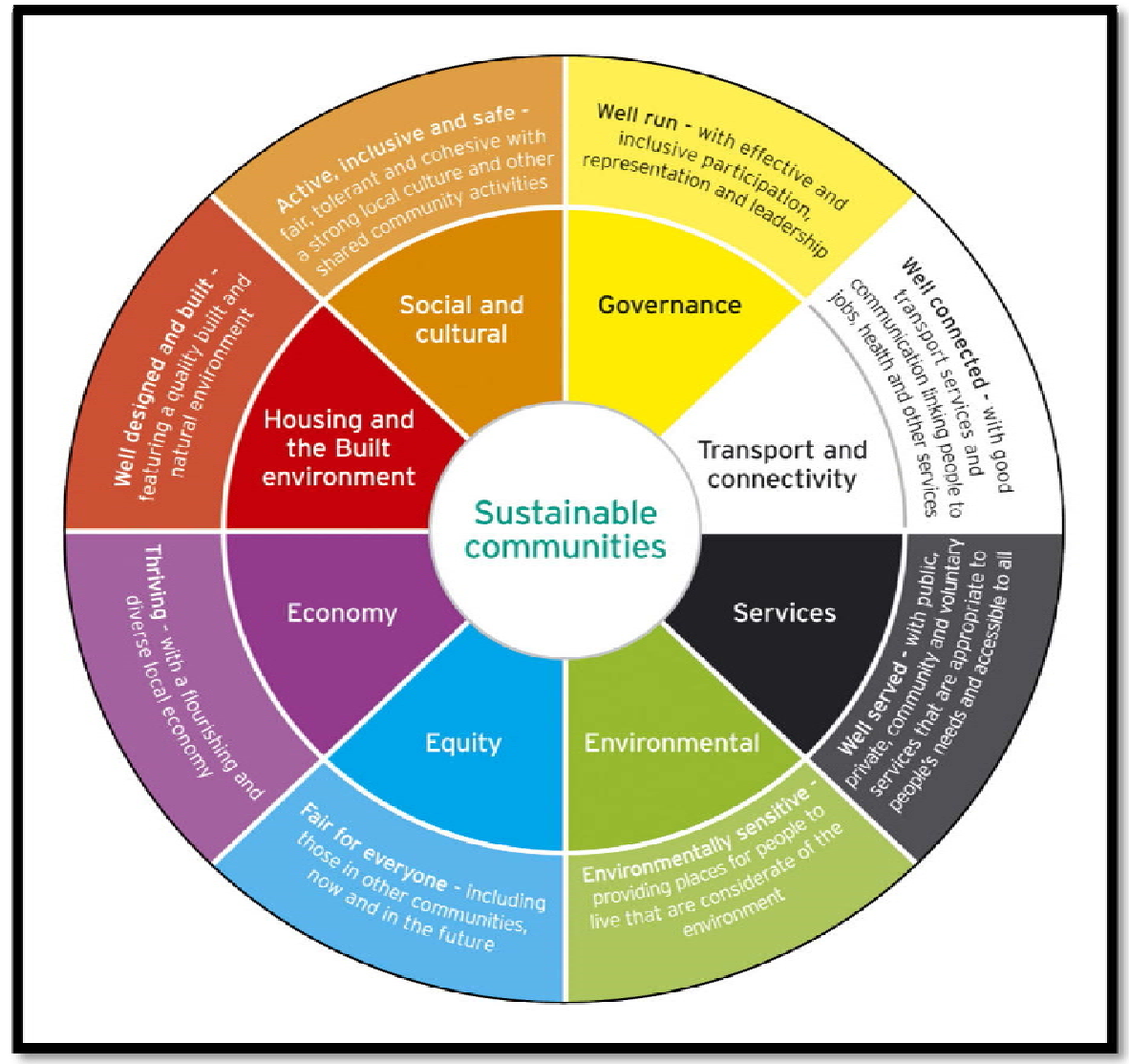

Figure 2.12 Diagram of the components of sustainable communities 
1. ACTIVE, INCLUSIVE AND SAFE - FAIR, TOLERANT AND COHESIVE WITH A STRONG LOCAL CULTURE AND OTHER SHARED COMMUNITY ACTIVITIES

Sustainable communities offer:

- $\quad$ a sense of community, cultural identity and belonging

- $\quad$ tolerance, respect and engagement with people from different cultures, background and beliefs

- friendly, co-operative and helpful behaviour in neighbourhoods

- $\quad$ opportunities for cultural, leisure, community, sport and other activities, Including for children and young people

- low levels of crime, drugs and antisocial behaviour with visible, effective and community-friendly policing

- $\quad$ social inclusion, equality of opportunity and good life chances for all.

2. WELL RUN - WITH EFFECTIVE AND INCLUSIVE PARTICIPATION, REPRESENTATION AND LEADERSHIP

Sustainable communities enjoy:

- $\quad$ representative, accountable governance systems which both facilitate strategic, visionary leadership and enable inclusive, active and effective participation by individuals and organisations.

- $\quad$ effective engagement with the community at neighbourhood level, including capacity building to develop the community's skills, knowledge and confidence. 
- $\quad$ strong, informed and effective partnerships that lead by example (e.g. government, business, community).

- $\quad$ strong, inclusive, community and voluntary sector.

- $\quad$ sense of civic values, responsibility and pride.

3. WELL CONNECTED - WITH GOOD TRANSPORT SERVICES AND COMMUNICATION LINKING PEOPLE TO JOBS, SCHOOLS, HEALTH AND OTHER SERVICES

\section{Sustainable communities offer:}

- $\quad$ transport facilities, including public transport, that help people travel within and between communities and reduce dependence on cars.

- facilities to encourage safe local walking and cycling.

- an appropriate level of local parking facilities in line with local plans to manage road traffic demand.

- $\quad$ widely available and effective telecommunications and Internet access.

- $\quad$ good access to regional, national and international communications networks.

4. WELL SERVED - WITH PUBLIC, PRIVATE, COMMUNITY AND VOLUNTARY SERVICES THAT ARE APPROPRIATE TO PEOPLE'S NEEDS AND ACCESSIBLE TO ALL

Sustainable communities have:

- local schools offering quality education, further and higher education institutions, and other opportunities for lifelong learning. 
- $\quad$ high-quality local health care and social services, integrated where possible with other services.

- $\quad$ high-quality services for families and children (including early years child care).

- $\quad$ good range of affordable public, community, voluntary and private services (e.g. retail, fresh food, commercial, utilities, information and advice) which are accessible to the whole community.

- $\quad$ service providers who think and act long-term and beyond their own immediate geographical and interest boundaries, and who involve users and local residents in shaping their policy and practice.

\section{ENVIRONMENTALLY SENSITIVE - PROVIDING PLACES FOR PEOPLE TO LIVE THAT ARE CONSIDERATE OF THE ENVIRONMENT}

\section{Sustainable communities:}

- $\quad$ provide places for people to live that respect the environment and use resources efficiently.

- $\quad$ actively seek to minimize climate change, including through energy efficiency and the use of renewable.

- $\quad$ protect the environment, by minimizing pollution on land, in water and in the air.

- $\quad$ minimize waste and dispose of it in accordance with current good practice.

- make efficient use of natural resources, encouraging sustainable production and consumption.

- $\quad$ protect and improve bio-diversity (e.g. wildlife habitats).

- $\quad$ enable a lifestyle that minimizes negative environmental impact and 
enhances positive impacts (e.g. by creating opportunities for walking and cycling and reducing noise pollution and dependence on cars).

- $\quad$ create cleaner, safer and greener neighbourhoods (e.g. by reducing litter and graffiti, and maintaining pleasant public spaces).

\section{THRIVING - WITH A FLOURISHING, DIVERSE AND INNOVATIVE LOCAL ECONOMY}

\section{Sustainable communities feature:}

- a wide range of good quality jobs and training opportunities.

- $\quad$ sufficient suitable land and buildings to support economic prosperity and Change.

- dynamic job and business creation, with benefits for the local community.

- a strong business community with links into the wider economy.

- $\quad$ economically viable and attractive town centres.

\section{WELL DESIGNED AND BUILT - FEATURING QUALITY BUILT AND NATURAL ENVIRONMENT Sustainable communities offer:}

- $\quad$ a sense of place - a place with a positive identity for people and local distinctiveness.

- $\quad$ user-friendly public and green spaces with facilities for everyone including children and older people.

- $\quad$ sufficient range, diversity, affordability and accessibility of housing within a balanced housing market. 
- $\quad$ appropriate size, scale, density, design and layout, including mixed-use development, that complement the distinctive local character of the community.

- $\quad$ high-quality, mixed-use, durable, flexible and adaptable buildings, using materials which minimize negative environmental impacts.

- $\quad$ buildings and public spaces which promote health and are designed to reduce crime and make people feel safe.

- $\quad$ buildings, facilities and services that are well prepared against disasters - both natural and man-made.

- $\quad$ accessibility of jobs, key services and facilities by public transport, walking and cycling.

\section{FAIR FOR EVERYONE - INCLUDING THOSE IN OTHER COMMUNITIES, NOW AND IN THE FUTURE Sustainable communities:}

- recognize individuals' rights and responsibilities.

- $\quad$ respect the rights and aspirations of others (both neighbouring communities and across the wider world).

- $\quad$ have due regard for the needs of future generations in current decisions and actions. (Bristol Accord policy papers from the Bristol meeting, 2005, pp.17-20)

\subsection{Eco-Villages}

"An eco-village is a sustainable community, which cares for its people and the earth in either a rural or an urban area, which may be an intentional community, a co-housing project or a rural landsharing (multiple occupancy) community" (David Kanaley, June 2000. Eco-Villages a sustainable lifestyle European Comparisons for Application in Byron Shire and New South Wales, page 2). However, not all intentional communities such as co-housing projects or rural 
land-sharing communities can be called eco-villages, since some of them have no ecological basis.

Eco-villages are small sustainable communities based on a specific ideology, shared by their residents, that promotes an alternative, sustainable lifestyle. They can act as models for the development of other sustainable communities. Australia is one country that has shown much interest in this type of community. A major GHG emitter, it is looking for ways to reduce the impact of industry on the environment.

David Kanaley, the director of Environmental Planning Services for Byron Shire Council in Australia, was awarded by the government and by the Shires Association of New South Wales the Australian Albert Mainerd Scholarship to research European eco-villages. The goal was to gain knowledge for the building of rural housing developments as sustainable communities in Byron Shire and New South Wales.

Mr. Kanaley chose the following European eco-villages as case studies:

- Torri Superiore, Ventimiglia, Italy

- Darmanhur, Baldissero (near Turin), Italy

- Lebensgarten, Steyerburg, near Bremen, Germany

- HjortshØj, near Arhus, Denmark

- Eco99, Arhus, Denmark

- Hooipolder, near s-Hertogenbosch, the Netherlands

- EVA Lanxmeer, Culemborg, the Netherlands

- Hockerton Housing Project, near Nottingham, England

- Findhorn, near Forres, Scotland

- Tweed Valley Eco-village, Scottish Borders Council, South of Edinburgh, Scotland.

These eco-villages throughout Europe presented diverse examples of sustainable communities. Researchers studied their formation and how they functioned. The resulting data showed that, while some characteristics were common to all eco-villages, others were specifically related to their locations and to the local culture and society. 
One important result of this research was the finding that eco-villages are formed around the social needs of their residents. They value social interaction and encourage a strong community spirit by, for instance, having community dinners.

\subsubsection{Key findings about eco-villages}

Research found that eco-villages decrease environmental loads and encourage alternative lifestyles in the following ways:

1. They recognise community.

2. They apply new technologies.

3. They are of varying sizes.

4. They provide for employment on site.

5. They need to be planned.

6. They must be car-free.

7. They need a social contract or social management plan.

8. They provide affordable housing on site.

9. They demonstrate an understanding of nature.

10. Local governments are essential to their success.

\subsubsection{Common elements of eco-villages}

Although developed within the framework of different countries' cultures and traditions, eco-villages share common elements, such as:

1. A common vision

2. Recognition of community

3. Understanding of nature

4. Application of technology to minimize adverse environmental impact

5. Use of passive solar design in housing

6. Production of some types of food

7. Internal decision-making system

8. Internal dispute resolution system

\subsubsection{Varying elements of eco-villages}

Distinctive elements that vary from one eco-village to another include: 
1. Some level of government support and the inclusion of 'social' (government) housing and some combination of rental housing

2. Private ownership of houses versus community ownership of houses

3. Communities of varying sizes (They can be as small as one family and as large as 2,000 people. However, it appears that a minimum of five to six houses is needed to have an effective, working eco-village.)

4. Intense community interest and participation in conception, planning, design and construction of the built environments

5. Shared religious beliefs contributing to community cohesiveness

\subsubsection{Eco-Villages and general summary of the findings}

David Kanaley summarizes his findings:

1. Eco-villages form because of the social needs of people.

2. There is an understanding that people need to live in a sustainable relationship with nature.

3. The size of an eco-village is based on what is comfortable for the founders of the village. This could range from 10 to 2,000 people.

4. Prospective future residents, a core group, should exist at the beginning of the planning process for an eco-village.

5. Eco-villages need a plan of management, which is agreed to by local government, and should include:

i) a concept plan

ii) an energy plan

iii) a design plan or guidelines for houses

iv) a landscape plan 
v) a pedestrian movement plan

vi) a water cycle management plan, and

vii) a social contract or social management plan.

6. Local governments need to provide guidelines, performance standards and/or identified sites for eco-villages in a strategic plan, as well as local environmental plans or development control plans where appropriate. Local governments can use their expert knowledge to provide help to the governing body of the community by, for instance, building cores for the eco-villages and providing technical support to assist in choosing appropriate sites and in utilizing the resources of near-by amenities. Local government involvement also can cut down on planning and construction struggles by providing appropriate project management guidance.

7. Eco-villages are more successful and sustainable if they provide for employment on site.

(Kanaley D. (2000). Ecovillages - A sustainable life style. European Comparisons for Application in Byron Shire and New South Wales)

\subsubsection{Case Study: Hjortshoj, near Aarhus, Denmark}

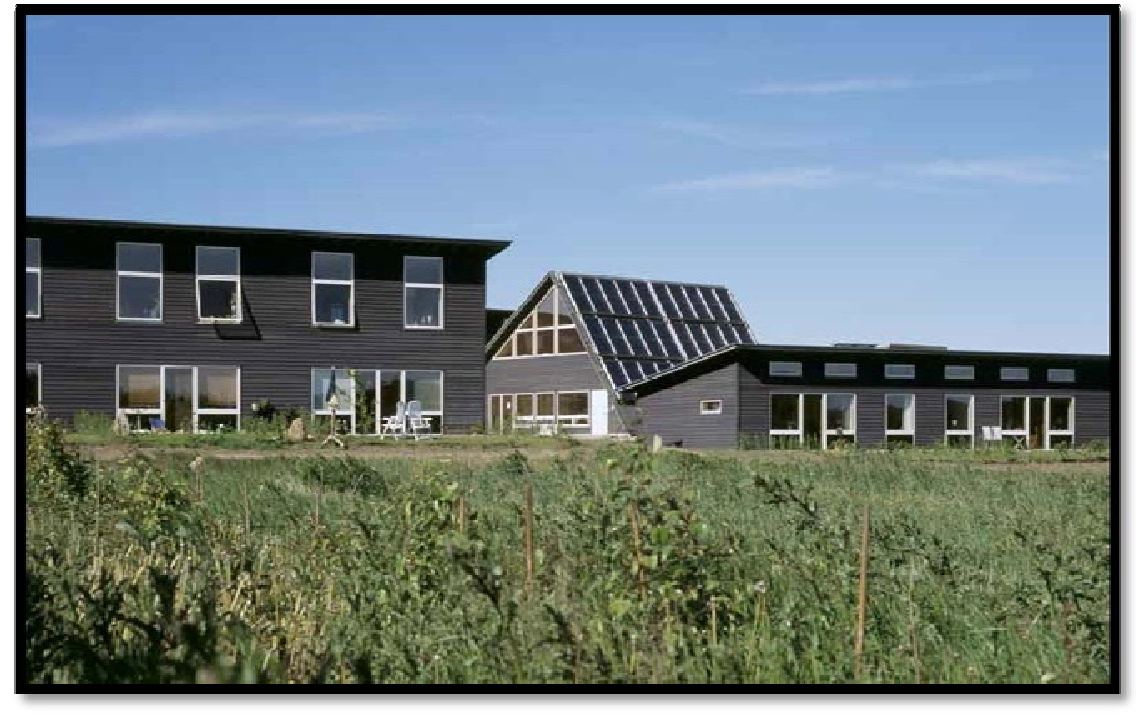

Figure 2.13: A view from Hjortshoj Eco-Village Group 4 housing
This eco-village consists of a number of cohouse groups of communities that started to evolve in 1991 and are still developing with new ones joining regularly. It is located $15 \mathrm{kms}$ from Aarhus main rail station and currently has 85 families. (Information retrieved from the website http://ecovillage.dk/58.html, December 2009) The local government provided 100ha of land at a very 
reasonable rental rate. Residents do not have big capital costs up front. As the village has expanded, new buildings have been added. The village is made up of a mixture of private and social housing. As part of the government initiative, the residents were carefully chosen to

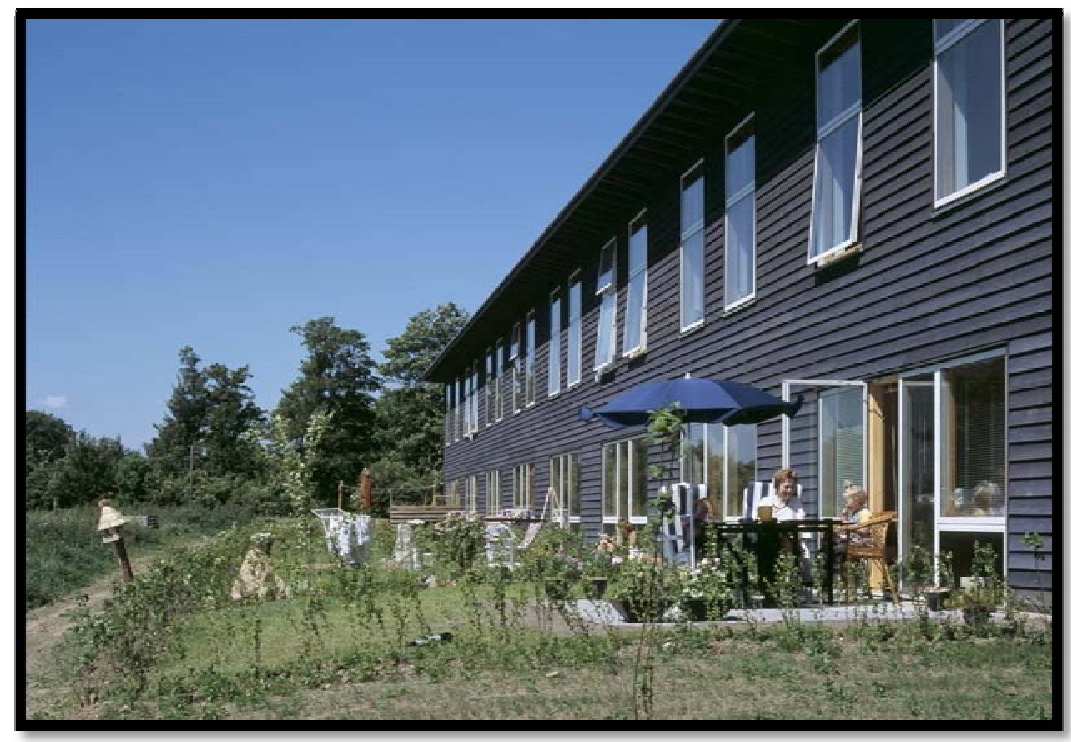

ensure that they were environmentally and ecologically knowledgeable.

They were even tested to gauge their understanding of ecological aspects of sustainable living and to ascertain that they had sufficient understanding of the project and its intent. The community has an open

Figure 2.14: Another view from Hjortshoj Eco-Village membership and it is an excellent example of government participation in eco villages.

(Kanaley D. (2000). EcoVillages - A sustainable life style. European Comparisons for Application in Byron Shire and New South Wales, p. 14)

Demographics of the site are as follows:

Association: $\mathrm{AiH}$ is an association, which is open to membership to everybody.

Membership fee: $300 \mathrm{DKK} /$ year $(\sim 60 \mathrm{CND})$

Members: About 85 families (130 adults). Most of them are living or plan to live at the Co-house groups of $\mathrm{AiH}$.

\section{Contact Address:}

Gammel Kirkevej 82, 8530 Hjortshoj, Denmark.

Location: North of Aarhus, $15 \mathrm{~km}$ from the main central train station. (3rd zone of Aarhus) 
Transport: Local train or bus No. 58 (both from Aarhus main train station)

Established: The village was founded in 1986 but was actually recognized as an ecovillage development in 1991 and has been expanding since then. (Kanaley D. (2000). EcoVillages - A sustainable lifestyle. European Comparisons for Application in Byron Shire and New South Wales, p. 13)

Co-house Groups: There are 5 Co-House Groups. 2 more are planned.

- $\quad$ Co-house Group 1: 10 families in twin houses

- Co-house Group 2: 20 families in row houses

- Co-house Group 3: 11 families in single houses and one twin house

- $\quad$ Co-house Group 4: 26 families in row houses

- Co-house Group 5: 18 families in row houses

Common Buildings: There are 4 Common Buildings and an Exhibition \& Office Building

\section{Common Buildings:}

- $\quad$ Common Building for Group 1 and 2 "Snail House" (used by Group 3 also)

- $\quad$ Common Building for Group 3 "Oval House" (constructed 2000-06)

- $\quad$ Common Building for Group 4 "Solhuset"; Common Building for Group 5

- $\quad$ Exhibition \& Office Building "Petersborg".

Offices include:Økotech Building Company, Rehearsal room for musicians in $\mathrm{AiH}$ OVE-Europe (Danish Organization for Renewable Energy). INFORSE-Europe (International Network for Sustainable Energy)

Residents: Data retrieved from the website is derived from about 85 families consisting of about 220 adults and children.

Lifestyle: AiH aims to be an example of a holistic way of living with sustainability as a keyword in respect to both ecological, economical and social aspects of life. This approach is visible in many aspects of daily life, some examples being: 
- $\quad$ Houses are built with an aim to be environmentally sustainable (i.e., made with rammed clay, earth blocks, wood, paper insulation, solar collectors, ovens, paint from linen oil, etc).

- Residents have the option to join a car-sharing association (two cars)

- $\quad$ There is an optional common dinner three days a week

- $\quad$ Fewer people have cars and more people use bicycles and bicycle trailers Residents are actively opposing a proposed highway near Hjortshøj

- A building company (Økotech) provides environmentally sustainable construction

- $\quad$ The Energy Association provides hot water from a wood-pellet and a wood chip burning boiler. (Cogeneration of Heat \& Power is planned with a sterling motor, which started in the spring of 2005)

- Common social events and celebrations (New Year, harvest celebration, art workshops etc.) are organized.

- $\quad$ Cultural evenings and days with music, dance, storytelling both for adults and children are provided.

- Michels's Eco-green, a commercial organic vegetable farming and organic ice cream producer, is open two times a week. (Tuesday and Friday)

- $\quad$ There are gymnastics for different age groups, dancing for children, and yoga in common facility

(Retrieved from the website http://ecovillage.dk/58.html, December 2009)

However, this village is far away from any larger urban centres and is therefore rather isolated. So, it does not present a good example of an eco-village in the sense of a community that interacts with the public.

Sustainable communities other than eco-villages provide insight into initiatives in diverse locations, environments and societies. An example is the Millennium Village.

\subsection{Millennium Villages, UK}

The English Partnership (the government's urban regeneration body) that is now a part of the Homes and Communities Agency ( $\mathrm{HCA})$, the new national housing and regeneration 
agency for England, was assigned a task by the government of the U.K. (in accordance with the Urban White Paper of November 2000) to plan and deliver sustainable community settlements throughout England. 6000 sustainable homes were to be delivered, as a part of the plan, by 2010 and another 7000 sustainable homes were supposed to be delivered through the new Millennium Communities Program by 2015. Through this program seven millennium villages in the U.K. have been established. These are Greenwich Millennium Village, London; Allerton Bywater Millennium Community near Leeds; New Islington Millennium Community; South Lynn Millennium Community; Telford Millennium Community; Oakgrove Millennium Community and Hastings Millennium Community. These communities are also planned to provide some 1,000 new jobs by providing $50,000 \mathrm{~m}^{2}$ of commercial space. (Retrieved from the website: http://www.englishpartnerships.co.uk/millcomms.htm, November 2009)

The Department of the Environment, Transport and Regions of the U.K. has been conducting research into these Millennium Villages to generate ideas about how such sustainable developments can be used to provide guidelines for other communities elsewhere and for the development of existing villages. Five different sites were chosen for comparison. Allerton Bywater, two Millennium Villages in Greenwich, West Silvertown, London (an urban village), Waltham Forest, London (a Housing Action Trust development), and the Duchy of Cornwall Poundbury scheme in Dorset.

The following points establish the department's goals:

1. To support subsequent development of sustainable communities (including housing developments and regeneration programs) in different contexts such as urban, suburban and rural areas.

2. To propose a general framework for subsequent evaluation of the Millennium Villages initiative and to transfer any valuable knowledge gained through research to feed back into current development of the Millennium Villages.

The U.K. government generated a table biased on research results that compares the five test sites. 
Table 1: Summary of evaluation results for the five test places

\section{Legend}

$\square$ Exemplary

$\square \quad$ Average $\square$ Better than Average

$\square$ Worse than Average $\square$ Mixed

$\square$ Under Construction

\begin{tabular}{|c|c|c|c|c|c|}
\hline \multicolumn{6}{|c|}{ Test Places } \\
\hline Aim & $\begin{array}{l}\text { Allerton } \\
\text { Bywater }\end{array}$ & Greenwich & Poundbury & $\begin{array}{l}\text { Waltham } \\
\text { Forest }\end{array}$ & West Silvertown \\
\hline $\begin{array}{l}1 \text { Resource } \\
\text { consumption }\end{array}$ & $\begin{array}{l}\text { - e.g. solar } \\
\text { design and } \\
\text { embodied } \\
\text { energy. } \\
\text { Public } \\
\text { transport } \\
\text { comparativel } \\
\text { y weak. }\end{array}$ & $\begin{array}{l}\text { - good public } \\
\text { transport. } \\
\text { Embodied } \\
\text { energy } \\
\text { proposals } \\
\text { could be } \\
\text { stronger. }\end{array}$ & $\begin{array}{l}\text { - uses local } \\
\text { materials and } \\
\text { craftsman, but } \\
\text { highly car } \\
\text { based. }\end{array}$ & $\begin{array}{l}\text { fairly } \\
\text { conventional } \\
\text { approach. }\end{array}$ & $\begin{array}{l}\text { - flagship } \\
\text { 'crescent block', } \\
\text { but high car } \\
\text { impact. }\end{array}$ \\
\hline $\begin{array}{l}2 \text { Environmental } \\
\text { Capital }\end{array}$ & $\begin{array}{l}\text { - former } \\
\text { colliery site } \\
\text { put to } \\
\text { productive } \\
\text { use. }\end{array}$ & $\begin{array}{l}\text { - ex } \\
\text { gasworks } \\
\text { transformed } \\
\text { into new } \\
\text { settlement. }\end{array}$ & $\begin{array}{l}\text { - Grade } 1 \\
\text { agricultural land } \\
\text { developed new } \\
\text { community } \\
\text { services/ } \\
\text { amenities } \\
\text { created. }\end{array}$ & $\begin{array}{l}\text { - upgrading } \\
\text { housing } \\
\text { estate. }\end{array}$ & $\begin{array}{l}\text { - disused docks } \\
\text { developed for } \\
\text { new } \\
\text { neighbourhood. }\end{array}$ \\
\hline $\begin{array}{l}3 \text { Urban design } \\
\text { quality }\end{array}$ & $\begin{array}{l}\text { - Promisses } \\
\text { high Urban } \\
\text { design } \\
\text { quality }\end{array}$ & $\begin{array}{l}\text { - innovative } \\
\text { design } \\
\text { intentions. }\end{array}$ & $\begin{array}{l}\text { - acknowledged } \\
\text { good practice. }\end{array}$ & $\begin{array}{l}\text { - fairly } \\
\text { conventional } \\
\text { approach. }\end{array}$ & $\begin{array}{l}\text { - quality } \\
\text { undermined by } \\
\text { parking and } \\
\text { highways. }\end{array}$ \\
\hline
\end{tabular}




\begin{tabular}{|c|c|c|c|c|c|}
\hline 4 Quality of life & $\begin{array}{l}\text { - up-grade of } \\
\text { existing off } \\
\text { site services } \\
\text { new } \\
\text { employment } \\
\text { opportunities. }\end{array}$ & $\begin{array}{l}\text { - possible } \\
\text { adverse } \\
\text { impact of } \\
\text { neighbouring } \\
\text { development, } \\
\text { (e.g. traffic } \\
\text { from } \\
\text { Sainsbury's } \\
\text { store). }\end{array}$ & $\begin{array}{l}\text { - contribution to } \\
\text { off-site services. }\end{array}$ & $\begin{array}{l}\text { good local } \\
\text { employment } \\
\text { and training. }\end{array}$ & $\begin{array}{l}\text { new services } \\
\text { relatively poor } \\
\text { training } \\
\text { opportunities etc }\end{array}$ \\
\hline $\begin{array}{l}5 \text { Equity/social } \\
\text { inclusion }\end{array}$ & $\begin{array}{l}\text { - proposed } \\
\text { locally mixed } \\
\text { community }\end{array}$ & $\begin{array}{l}\text { - attempts to } \\
\text { 'pepper-pot' } \\
\text { tenures. }\end{array}$ & $\begin{array}{l}\text { - well-integrated } \\
\text { social housing. }\end{array}$ & $\begin{array}{l}\text { - mixed } \\
\text { tenure } \\
\text { housing new } \\
\text { community } \\
\text { facilities. }\end{array}$ & $\begin{array}{l}\text { - most social } \\
\text { housing } \\
\text { segregated. }\end{array}$ \\
\hline 6 Participation & $\begin{array}{l}\text { extensive } \\
\text { public - } \\
\text { involvement } \\
\text { proposed } \\
\text { Village Trust. }\end{array}$ & $\begin{array}{l}\text { wide ranging } \\
\text { powers for } \\
\text { Village Trust, } \\
\text { but } \\
\text { limited public } \\
\text { participation } \\
\text { exercise. }\end{array}$ & $\begin{array}{l}\text { management } \\
\text { company locally } \\
\text { run, but } \\
\text { top-down design } \\
\text { process }\end{array}$ & $\begin{array}{l}\text { - effective } \\
\text { participation } \\
\text { of voluntary } \\
\text { sector. }\end{array}$ & $\begin{array}{l}\text { - successful } \\
\text { participation } \\
\text { exercises } \\
\text { throughout } \\
\text { development } \\
\text { process. }\end{array}$ \\
\hline $\begin{array}{l}7 \text { Commercial } \\
\text { viability }\end{array}$ & $\begin{array}{l}\text { - private } \\
\text { funds } \\
\text { intended to } \\
\text { balance large } \\
\text { public outlay. }\end{array}$ & $\begin{array}{l}\text { - intended to } \\
\text { be } \\
\text { commercially } \\
\text { viable. }\end{array}$ & $\begin{array}{l}\text { - increased } \\
\text { costs balanced } \\
\text { by uplift in } \\
\text { house values. }\end{array}$ & $\begin{array}{l}\text { - initial public } \\
\text { funds and } \\
\text { dowry for } \\
\text { ongoing } \\
\text { management }\end{array}$ & $\begin{array}{l}\text { - high value } \\
\text { housing offsets } \\
\text { public } \\
\text { investment in } \\
\text { infrastructure. }\end{array}$ \\
\hline 8 Integration & & & & & \\
\hline
\end{tabular}


(Comments in the table derived from the website

http://www.communities.gov.uk/publications/communities/milleniumvillages, November 2009)

- The research based on the eight criteria led to some recommendations being made to improve sustainable communities within the framework of sustainable communities.

- $\quad$ Sustainable communities should adopt the eight goals as key factors for development and evaluation.

- The most important criteria for site selection should be the potential to achieve a viable sustainable settlement, rather than meeting criteria for funding packages or political symbolism.

- $\quad$ Availability of sustainability infrastructure (such as good public transport or good quality local public services) and a pool of potential residents likely to value the sustainability features are high priorities.

Sustainable communities should be checked periodically to monitor their progress and to answer questions such as:

1. What are the experiences of community members living in a sustainable environment? What can be improved?

2. What are the most important factors that will advance the community further economically? Is there anything that could improve community economic wellbeing?

A questionnaire assembled by the experts of the governing body of the community and expert help from the local government will assist in measuring the success of sustainable communities. "Success" will be hard to objectify since people will have different opinions. However, it is imperative to identify and address issues that affect the community early in its development and periodically thereafter. 
Research shows that, generally speaking, sustainable communities in the U.K. face a challenge in that they present lifestyles that contrast with the traditional ones of that country. However, the report also suggests that government support is helpful in planning and maintaining sustainability, for instance, by providing tax easements. Government can also reward developers who provide good sustainability and penalize those who damage the environment. The chart provides a framework within which the success of sustainable communities can be measured, by establishing criteria such as the quality of life, resource consumption, commercial viability etc. This could be a great tool for all sustainable communities for assessing their success, needs and drawbacks.

The Millennium Villages research report looks into a wide range of sustainable developments in urban and suburban areas. Some are entirely new; some, like the Allerton Bywater rural development, were additions, and others were retro-fitted into an area that is no longer viable, for instance, West Silvertown. The Allerton Bywater case study is of particular interest, since these types of developments are being proposed for Ontario.

\subsubsection{Case Study: Allerton Bywater, U.K.}

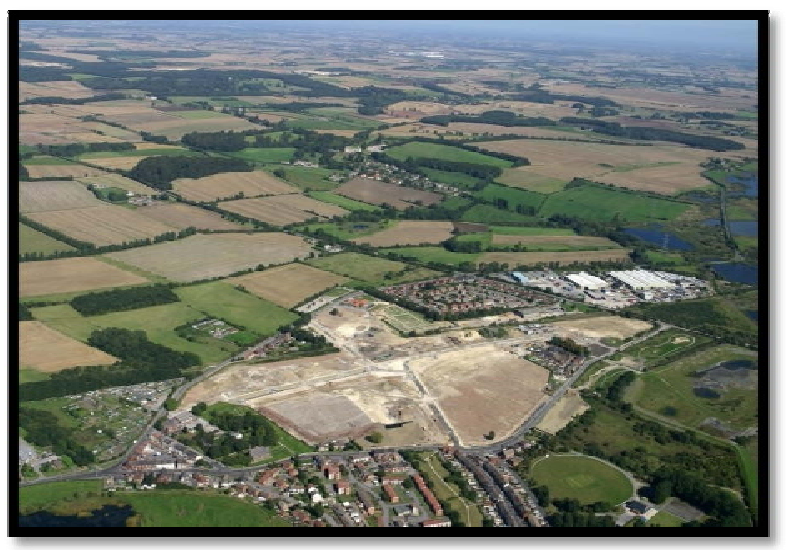

This sustainable community development aims to revive an old village that has been disappearing since its coal mine was closed in 1992 and all the workers became unemployed. The new development would include approximately 520 new housing units. Its 24-hectare site is being converted to a development approximately $12 \mathrm{~km}$ (7 miles)

Figure 2.15 A view from the development site south-east of Leeds. 4,000 people currently live in Allerton Bywater, which is a big potential for work and employment opportunities; $25,000 \mathrm{~m}^{2}$ of commercial work and community space will be provided. 


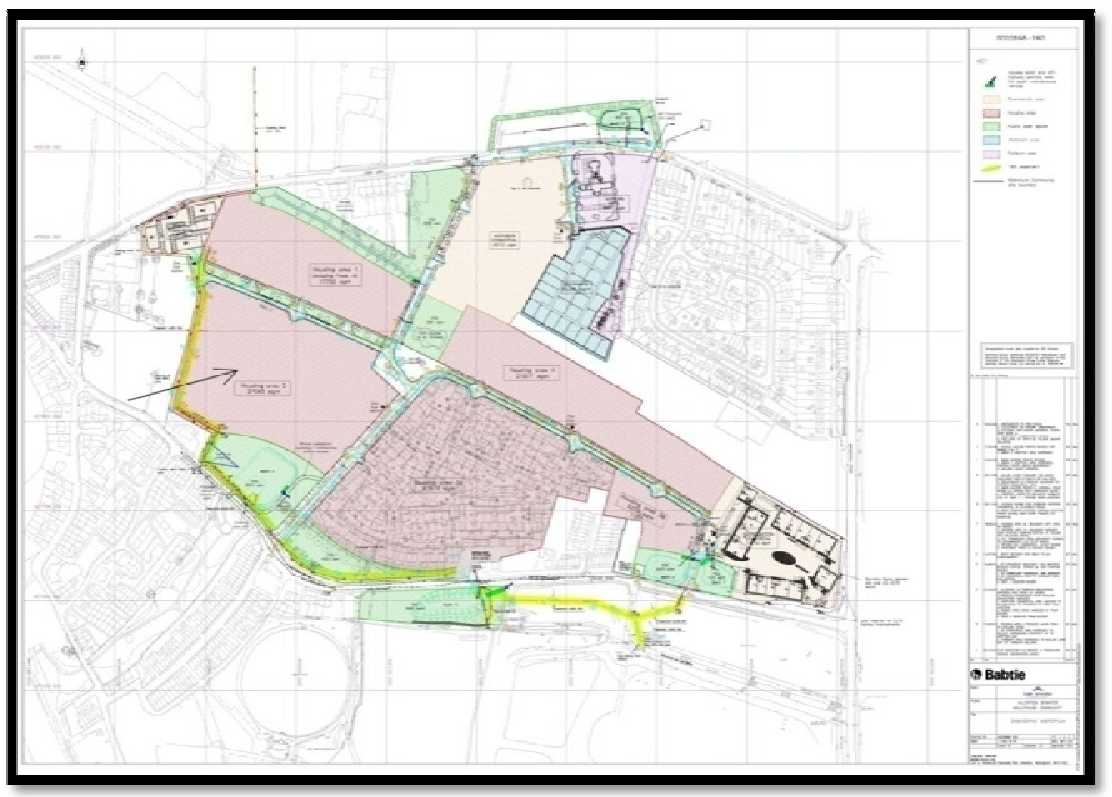

Figure 2.16 Development Plan of Allerton Bywater Millennium Village in the U.K.

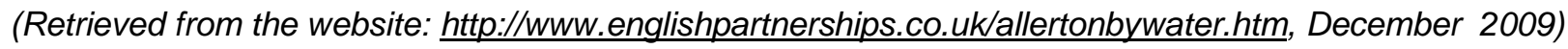

The development is part of the Millennium Villages Program in the U.K. and divided into major lots. The development of these lots will provide sustainable design with differentiating

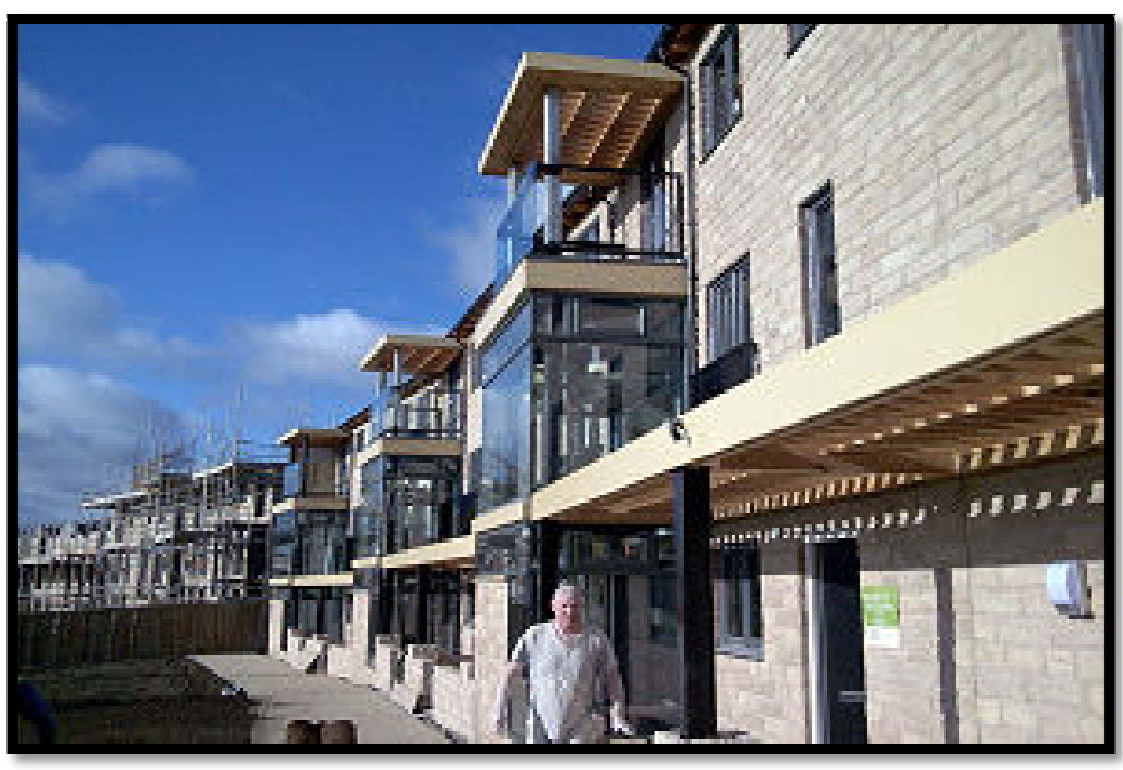
architectural expressions. Each division of the site is assigned to a different design built firm. The infrastructure construction of the site started in 2003 and the last house delivery for Area 2 was planned for the end of 2009. (Retrieved from the website

Figure 2.17 A view from A2 section development. Glazed sun rooms and open terraces are desirable architectural elements that provide transparency and social interaction. 
http://www.designformanufacture.info/allertonbywater, December 2009)

The Millennium Villages development also tries to achieve the creation of public spaces beside sustainable, well-built homes, and follow the goals of the Millennium Village Program sustainable frame work principles as described earlier. Almost 2 million British pounds $(\$ 3,405,000.00 \mathrm{CND})$ were spent to establish common spaces by the renovation of an old school and miners' welfare hall where the community can meet. The housing areas have been turned into pedestrian-friendly housing zones where car access is limited. Transportation has been established with a car-pooling and rental car club, Whizz-Go car club, that provides transportation with low-emission cars under the Green Transport development of the U.K.

The increased density of the site allows for a work/live /shop environment that is welcome to the residents of the area. The firm Network Space has been hired to manage the commercial developments that will help revitalize the area by increasing economic activity.

Allerton Bywater is more than an attempt to revive an old dying village. With the arrival of the Millennium Villages Program and with sustainability as the base, the village can reactivate its economy supported by increased population density and energy saving measurements. It is also evidence that sustainable communities with a sustainable environment and lifestyle can turn around losing economies and provide good quality built housing at costs to its owners as low as $£ 60,000$ ( $\$ 101,000 \mathrm{CND})$.

\subsubsection{Case Study: Sustainable community planning, Batawa, Ontario}

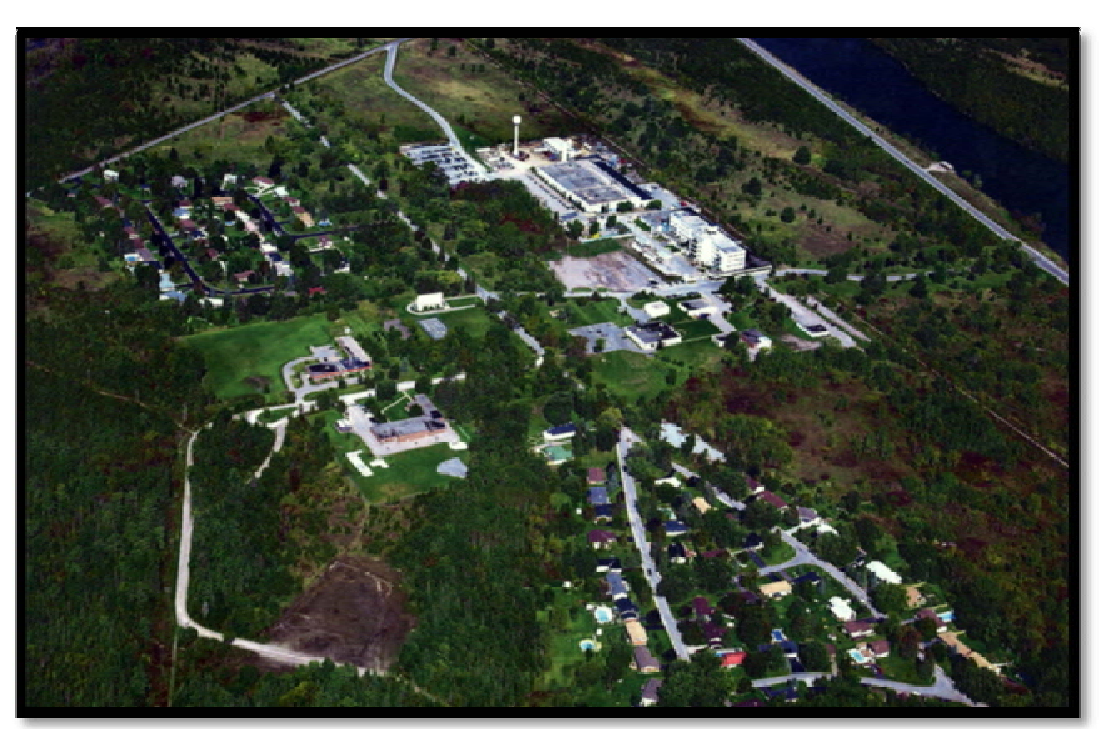

Figure 2.18 A view above Batawa, Ontario
This development is similar to the sustainable development in Allerton Bywater in the U.K., as it has the same goal of reviving an existing area and providing for economic growth. It is also an example of how a rural area that boasts natural beauty (with its proximity to the Trent River) can benefit from tourism. 
In 1999, after 60 years of production, the Batawa, Ontario Bata Shoe Factory closed; it had employed as many as 1,000 people at its peak. After the close of the factory, the companyowned land was bought back by Sonja Bata, the widow of Thomas J. Bata, founder of the Bata Shoes Company and the Bata Development Corporation was founded. Under her leadership,

Bata Development Corporation developed a proposal for a sustainable community adjacent to the existing village that would be pedestrian oriented and mixed-use and would incorporate principles of the sustainable urban design guidelines of new urbanism and smart growth.

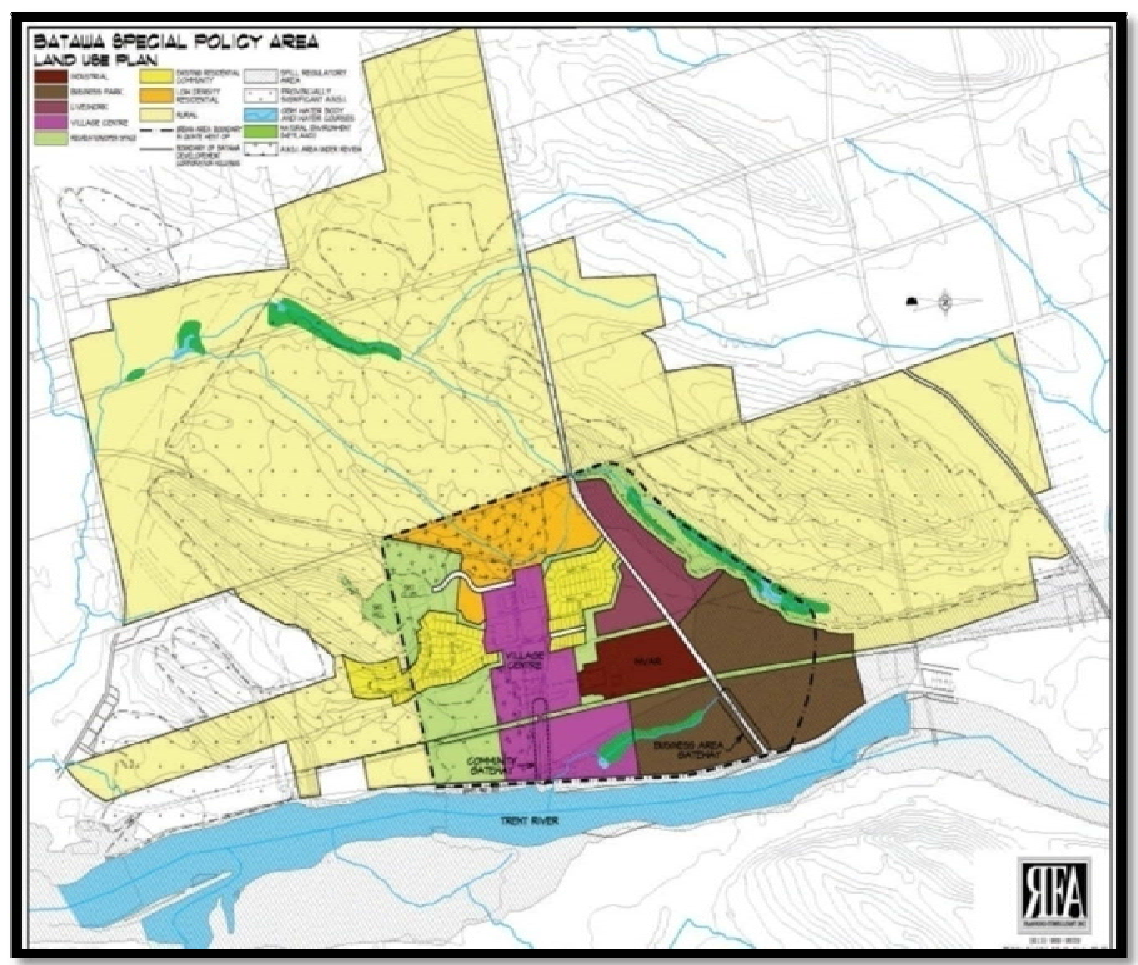

Figure 2.19 Sustainable Development Plan of Batawa, Ontario
The town centre will be a sustainable mixed-use development with a community centre and spaces for social networking. A business park with a 42-hectare commercial and industrial area, and a 12.6-hectare integrated live/work area of over 50 lots/units with lots ranging in size from 760 square meters to 5,600 square meters are also within the development proposal. A low-density residential development is

proposed with 140 homes over 18.5 hectares. Large landmark buildings such as a Catholic church and a school will be maintained. The target of the project is to create a sustainable community within a sustainable site that will bring economic vitality into the area and restore lost jobs .

The development will be based on the LEED's (Leadership in Energy and Environmental Design) neighbourhood development benchmark which is a pilot program of the United States Green Council and which has been adopted by the Canadian Green Building Council. Based on 
the neighbourhood development guidelines, the site will feature a network of walking trails that will create not only an attraction for the visitors to the skiing town but also encourage walking and create a walkable neighbourhood in a mixed-use environment. Plans for new economical prosperity for the area are encouraged by the fact that Batawa is home to the only Alpine ski hill with multi-seasonal amenities in Ontario; this will help build up the town's economy and offer employment opportunities to its residents.

\subsubsection{Case Study: Greenwich Peninsula, London, U.K.}

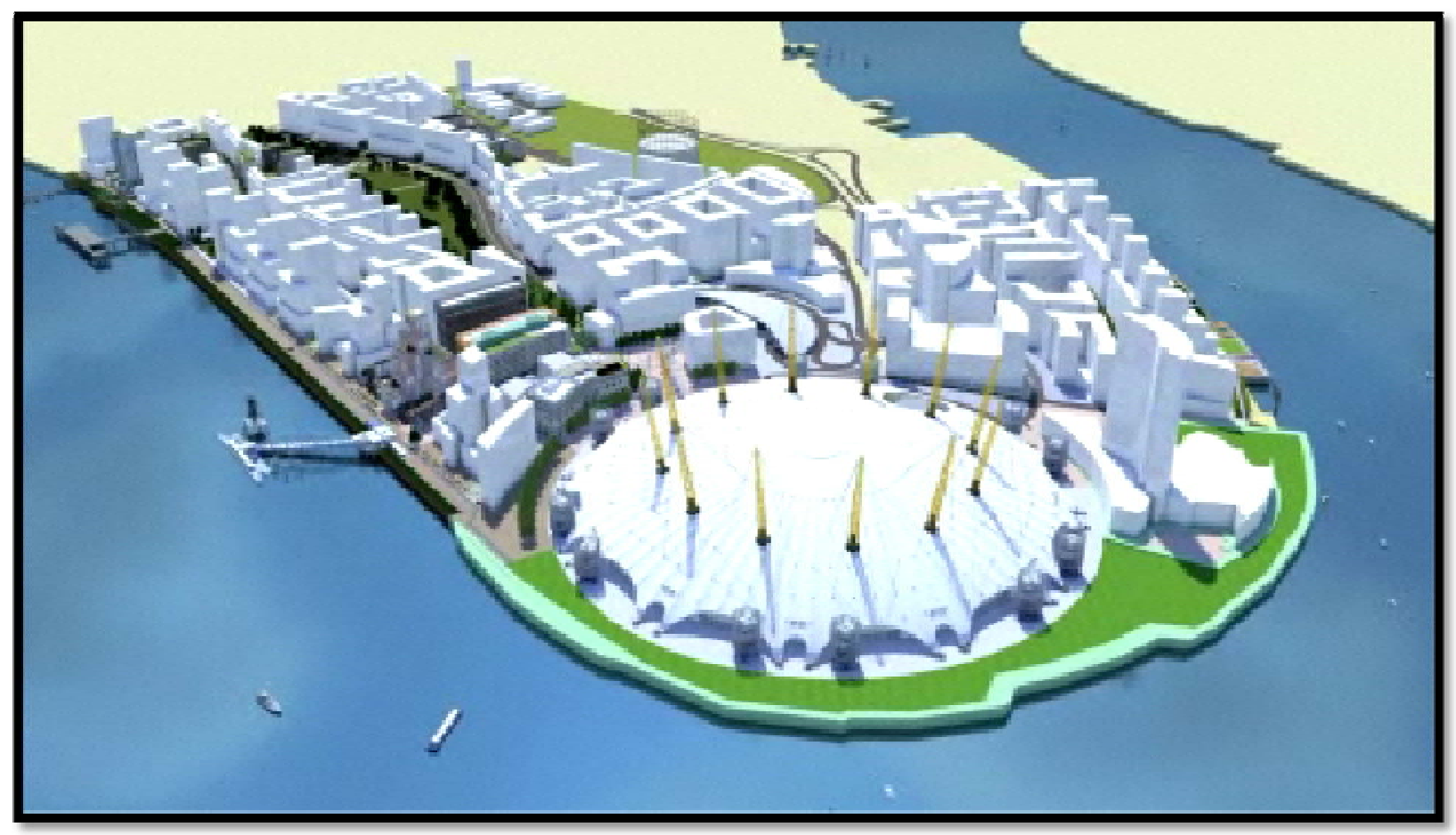

Figure 2.20 Sustainable Greenwich peninsula brownfield development beside Millennium Dome, London, U.K.

This is a 217 -million pound ( $\$ 367,654,093 \mathrm{CAD})$, 80 -hectare massive brownfield redevelopment. The goal is to integrate this development into the site of the Millennium Dome in London. It is expected to be completed in time for the 2012 London Olympics. The immense site will also be home to more than 20,000 people and provide 24,000 jobs. It will provide 1.4 million square metres for retail, commercial and entertainment purposes and approximately 13,000 residential homes of which 3,800 will be affordable housing. 
The site offers easily accessible public transportation and will provide a highly developed pedestrian and cycle network and 50 acres of parkland. A low-energy supermarket, built in 1999, was the first low-emission zone of London, UK. The Greenwich Peninsula project contains 3,000 high quality ecologically friendly homes and will provide walkways over 2 kilometres long alongside the Thames River.

This case study was chosen as one of the key case studies of the Millennium Villages research program and achieved an evaluation mark of "excellent" for its environmental capital value and innovative urban design qualities. For example, converting existing gas works on

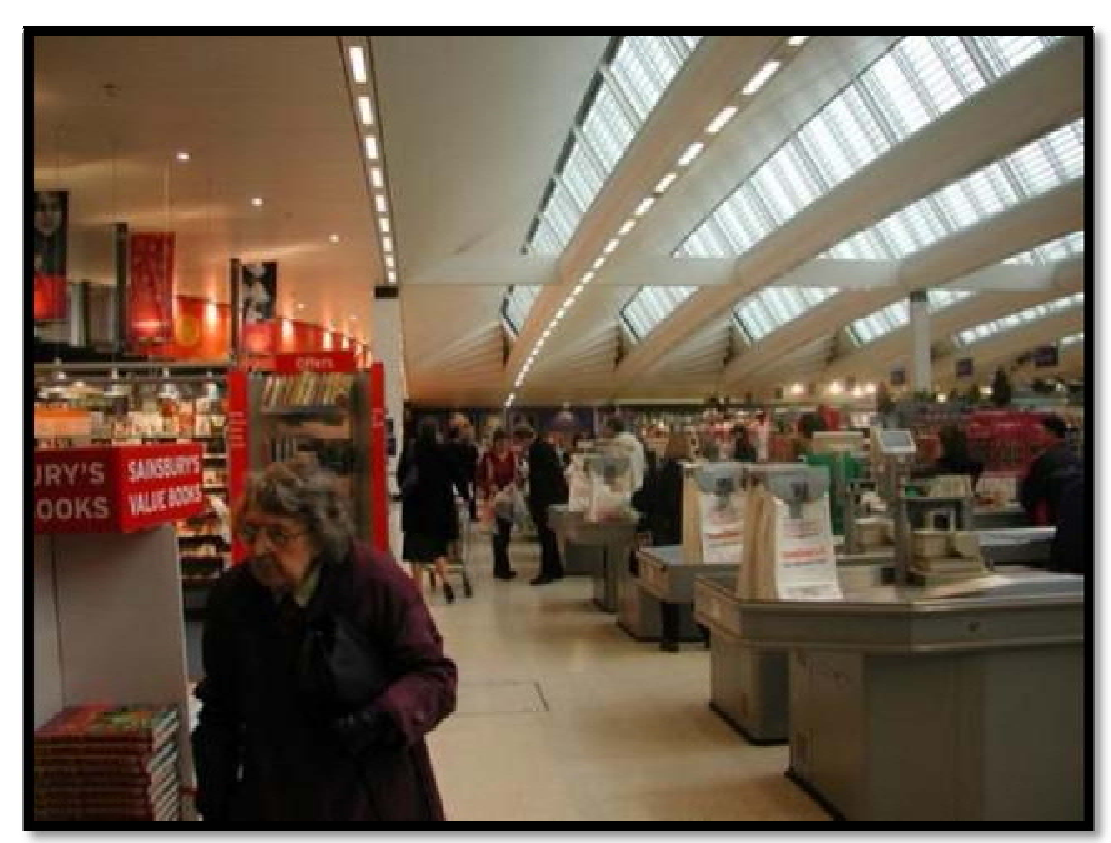

Figure 2.21 A view from the inside of the grocery store of Greenwich peninsula brownfield development, London, U.K. brownfields has provided invaluable benefits to the surrounding community and employment opportunities. The innovative 21 st century design of a grocery store of the development exceeded all expectations. After a long research (three years) designers have been able to achieve a $50 \%$ more energy efficient grocery shop than a standard supermarket by using low energy technologies such as alternative energies.

Heated floors, natural lighting and solar shading on the south side of the building have contributed to its energy efficiency. The building has achieved a rating of "excellent" under the Building Research Establishment's Environmental Assessment Method. (Retrieved from the website http://www.cabe.org.uk/case-studies/sainsburys-supermarket-greenwich-peninsula/design, December 2009)

The case study shows that creating sustainable places does not necessarily depend on size. Although projects can be this large, better and energy efficient buildings can be provided. Converting old, industrial, contaminated brownfields to more desirable living places is one the major goals of sustainability. 


\subsection{City of Toronto and sustainability}

\section{Recent Immigrant (2001-2006) Percentage of the Population by Census Tracts, Toronto CMA, 2006}

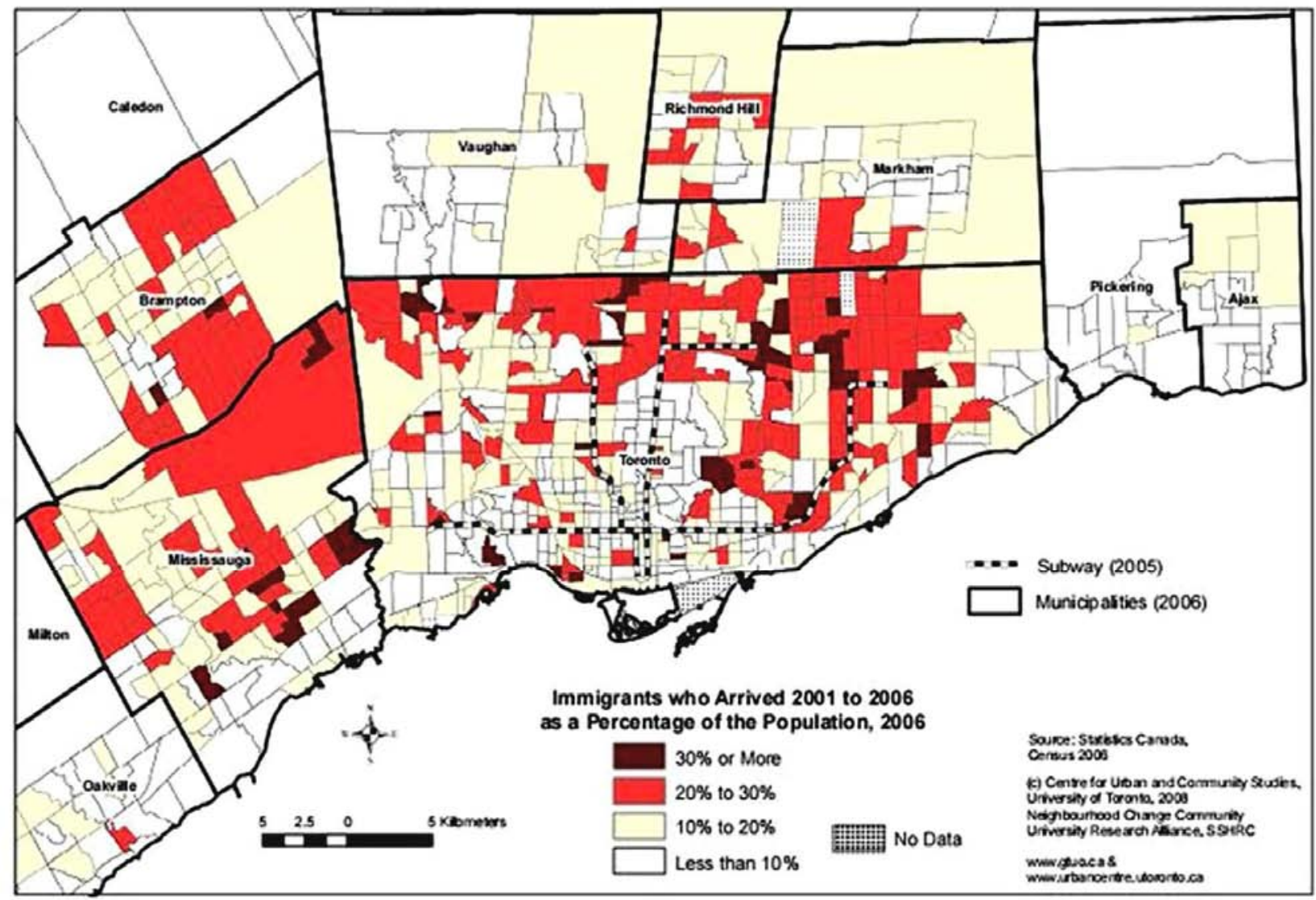

Figure 2.22 Map of Immigration spread of the city Toronto

The city of Toronto is the largest city in Canada and sustainable developments are also needed desperately here, just like in all other cities of North America. Like every city, Toronto has a great impact on the environment. There is a substantial amount of new housing: new buildings are needed to satisfy the demand based on the population growth of Toronto. Toronto's population is increasing. steadily not only because of initial low population growth but mainly because of immigration of new Canadians coming to Canada and especially to areas where finding work is more possible. The Greater Toronto Area (GTA) had a population of 4,682,897 in 2001 and since then an increase in the population can be seen, based on census data gathered by Statistics Canada. Currently 5,113,149 million people live and work here in the GTA (See Figure 2.25) The attractiveness of metropolitan Toronto has been growing as 
Canada's overall population grows. Paralleling the city's development, residential

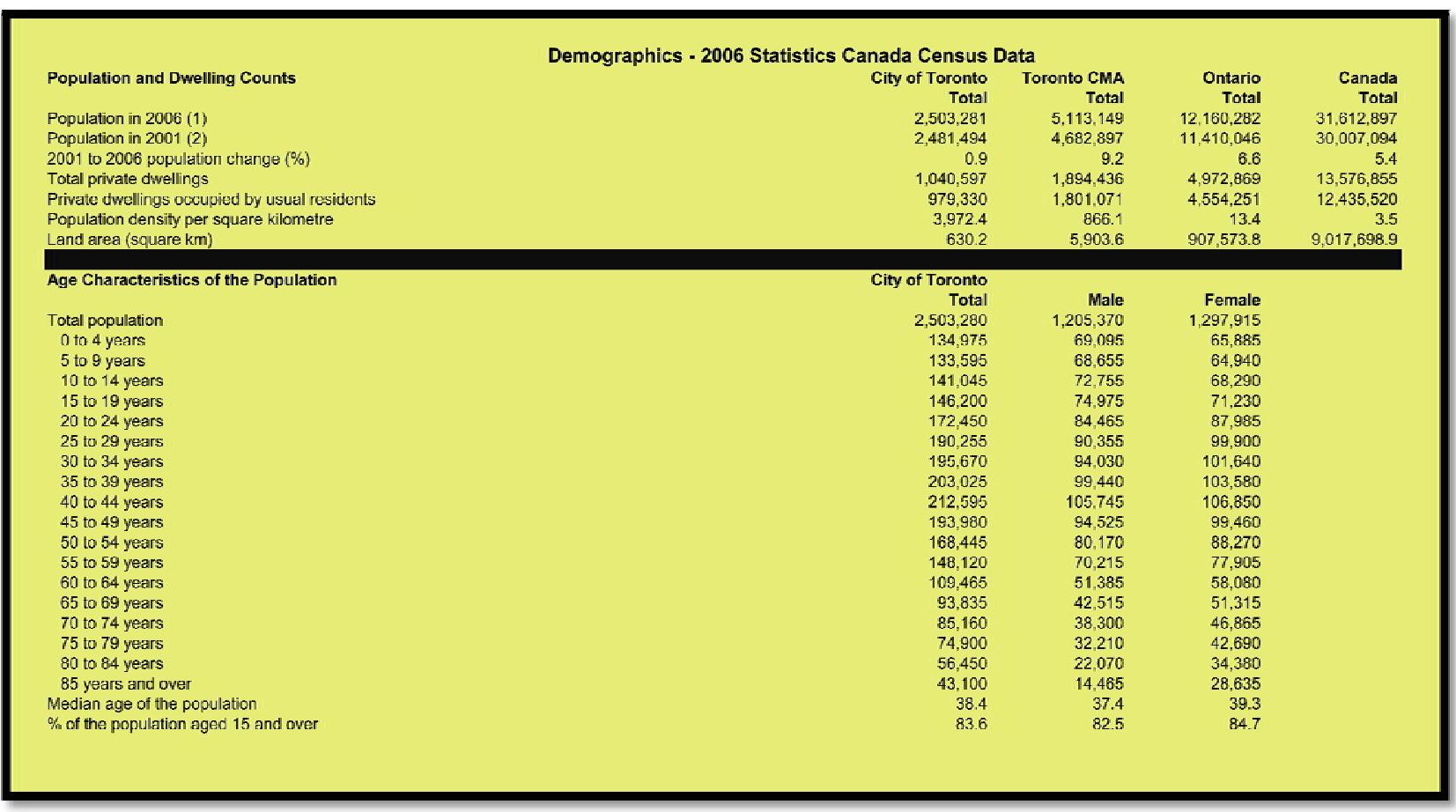

Figure 2.23: Canadian 2006 census data showing the population increase between 2001-2006

construction has been expanding rapidly, but away from the city core and towards farmlands.

These housing developments are mainly residential single-family, semi-detached or detached townhouse developments. Unfortunately, some of this housing had been developed on farmlands with rich soil for farming. Today, thanks to greenbelt zone protection, green areas and farmlands near Toronto have been made officially off-limits for development. However, not far from Toronto, near Lake Simcoe and Barrie, Ontario, massive townhouse developments have been established that by-pass greenbelt by-Laws. (Mittlestaedt M. (2008). Ontario's greenbelt a model for the world. Globe and Mail, Toronto. Website:

http://www.oakridgestrail.org/NewsDocuments/globeandmail Apil10-08l.pdf ). In this kind of development, people are isolated from each other and there is really no place for shopping, working or entertainment that is reachable without the use of cars, as public transit cannot be supported at such low densities. 


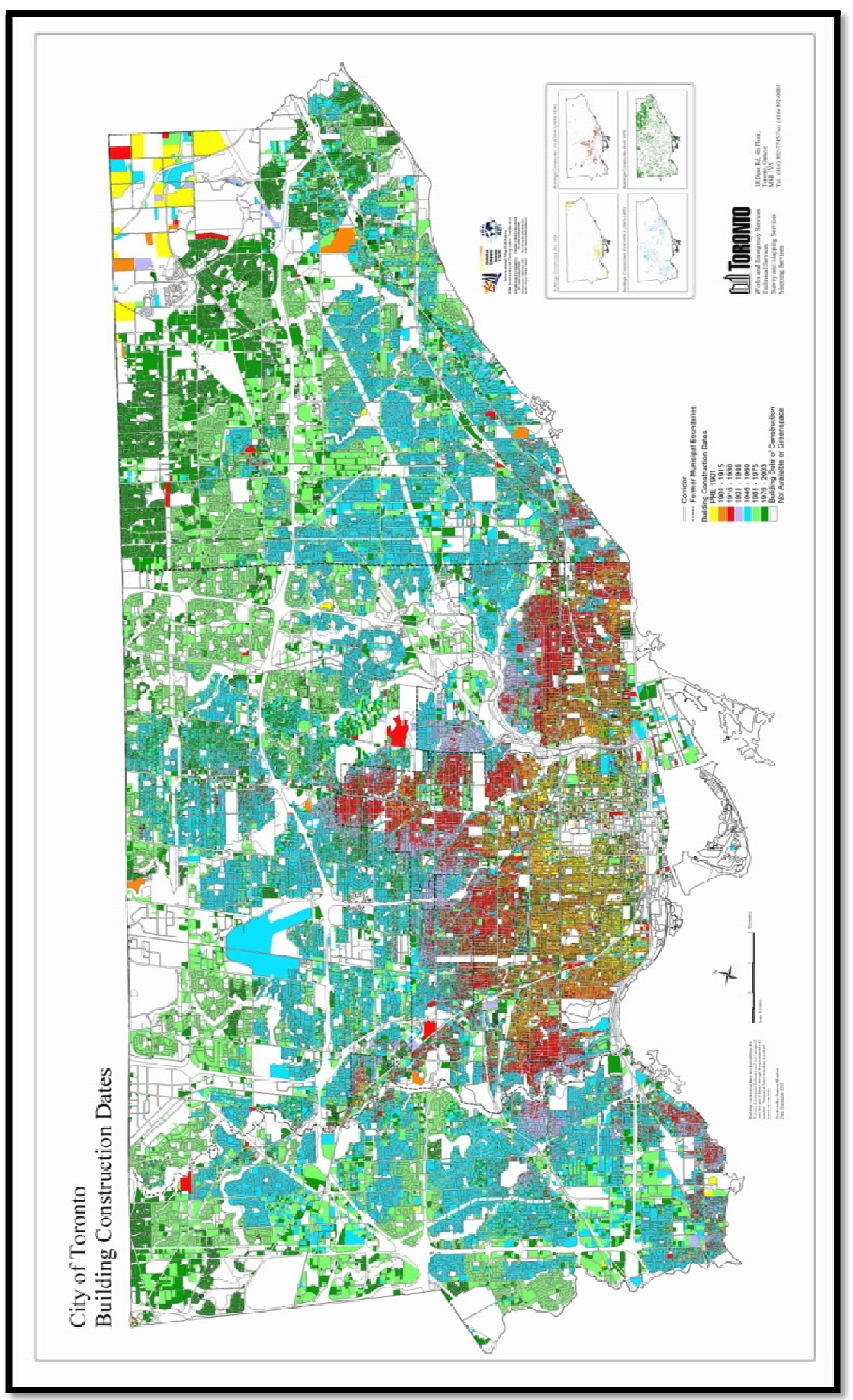

Figure 2.24: Construction history map of the city Toronto 
One typical example of this usuburban growth is the development of Markham, a town northeast of Toronto. It is a typical residential development with car parking in front of houses. The reality is that this type of development is unsustainable, since residents of these developments have to commute by car to work, to school and for shopping. Close by these developments there is usually a shopping centre created for the

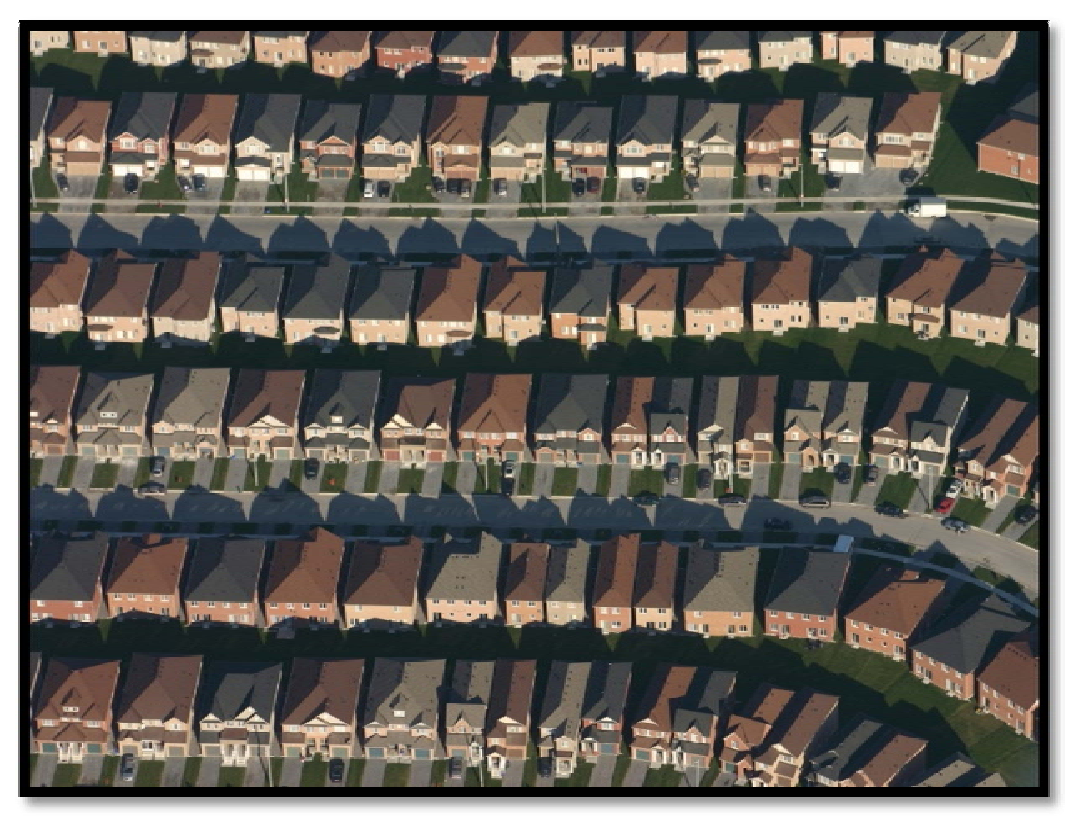

Figure 2.25: Townhouses in Markham, Ontario residents of the surrounding area and reachable by cars only. These single-family residential buildings are not energy efficient, since there is no sharing of heating or cooling or of any type of energy that will reduce the consumption of the buildings. The reason for that is that since these are residential buildings, they remain heated but empty during the day and occupied at night and maybe on weekends only. If they are commercial buildings such as shopping centers or office buildings, they will remain occupied during the day but not at night-time. These buildings might have been well constructed; however, their single-use alone is one obstacle in the achievement of sustainability. Since people living in suburbs have no choice but to reach their destination by private commuting, this brings attention to the transportation network of Toronto, which is a very important factor in the sustainability of a city. These are not R-2000 energy efficient homes that are approximately 30 percent more energy efficient houses that are introduced to the market by in collaboration with The Canadian Home Builders' Association and Natural Resources Canada's (NRCan's) Office of Energy Efficiency which manages R-2000 on behalf of the federal government in support of R-2000 technology, builders and consumers. (Ref: http://r2000.chba.ca/What is R2000/index.php, December2009)

\subsubsection{The transportation network of Toronto}

Looking at the transportation network of Toronto, one realizes that there are a lot of roads and cars but that public transportation is not effective in terms of providing mass transportation. 
Table 2: Census data showing transportation methods to work

Employed labour force by mode of transportation to work, by census metropolitan area (2006 Census)

(Ottawa-Gatineau, Kingston, Peterborough, Oshawa, Toronto)

2006

\begin{tabular}{|l|lllll|}
\hline $\begin{array}{l}\text { Ottawa- } \\
\text { Gatineau } \\
\text { (Ont.-Que.) }\end{array}$ & (Ont.) & (Ont.) & (Ont.) & (Ont.) \\
\hline & number & & & \\
\hline
\end{tabular}

Total - modes of

transportation

$559,590 \quad 69,530 \quad 52,115$

$160,0102,433,060$

Car, truck or van, as driver

350,960

50,850

39,795

$126,340 \quad 1,547,540$

Car, truck or van, as

passenger

44,880

6,445

5,180

$13,805 \quad 182,440$

Public transit

108,840

2,865

1,280

$12,665 \quad 540,495$

Walked to work

38,335

6,690

4,075

$5,430 \quad 115,625$

Bicycle

11,640

1,660

1,215

650

24,690

Motorcycle

720

50

$100 \quad 1,540$

Taxicab

605

100

39

Other method

3,620

435

155

395

4,800

Source: Statistics Canada, 2006 Census of Population.

Last modified: 2009-09-17. 
If we look at the amount of car travel compared to public transportation, it is clear that car transportation is more popular. Like many other North American cities, Toronto has been taken over by private transportation and cars. Until recently, oil prices had been increasing but this did not have any significant effect on the use of cars as the major means of

transportation since, in many cases, there was no

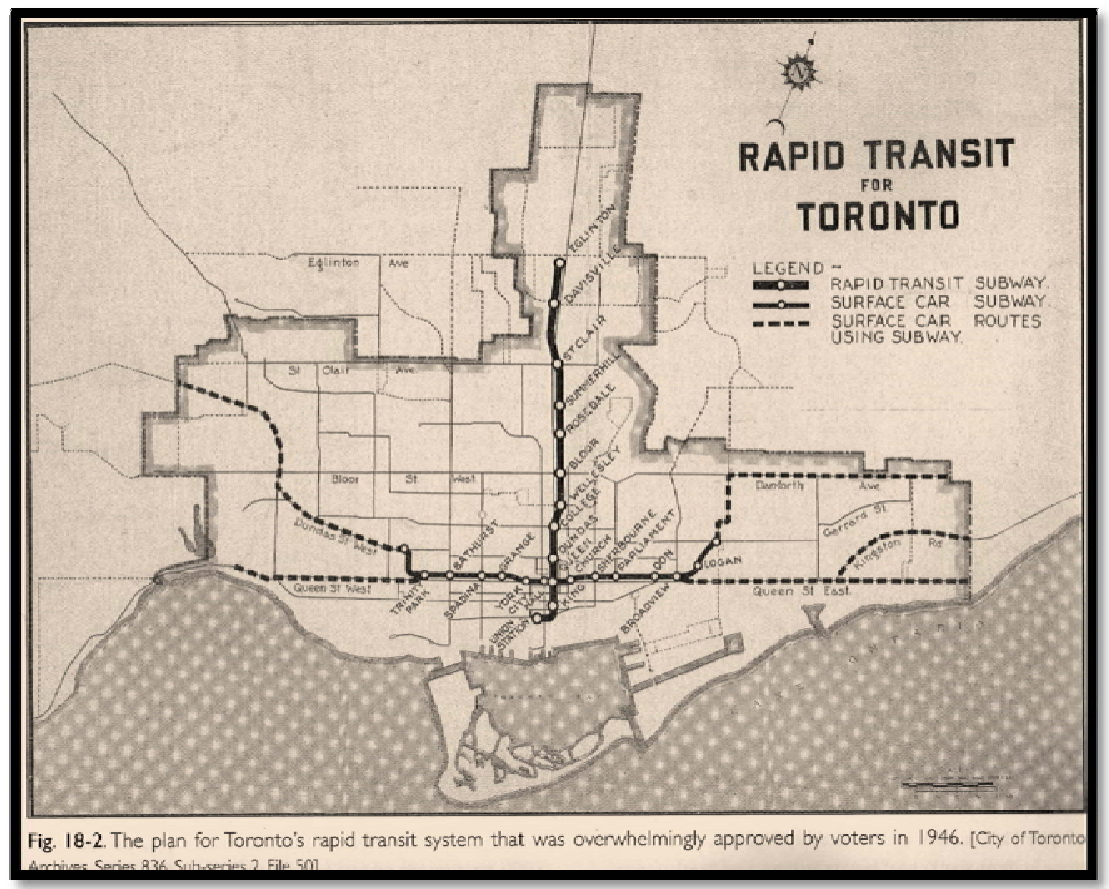

Figure 2.26: In 1946 planed rapid transit light railway lines of Toronto. alternative. Of course the influence of North American carcompanies and related industries on the development of roads and the underdevelopment of public transportation cannot be overemphasized. The fact is, as a result of population growth the number of car owners has increased, and roads have been developed, but the public transportation network has not developed very effectively. For example, the main public mass transportation spine, the Toronto

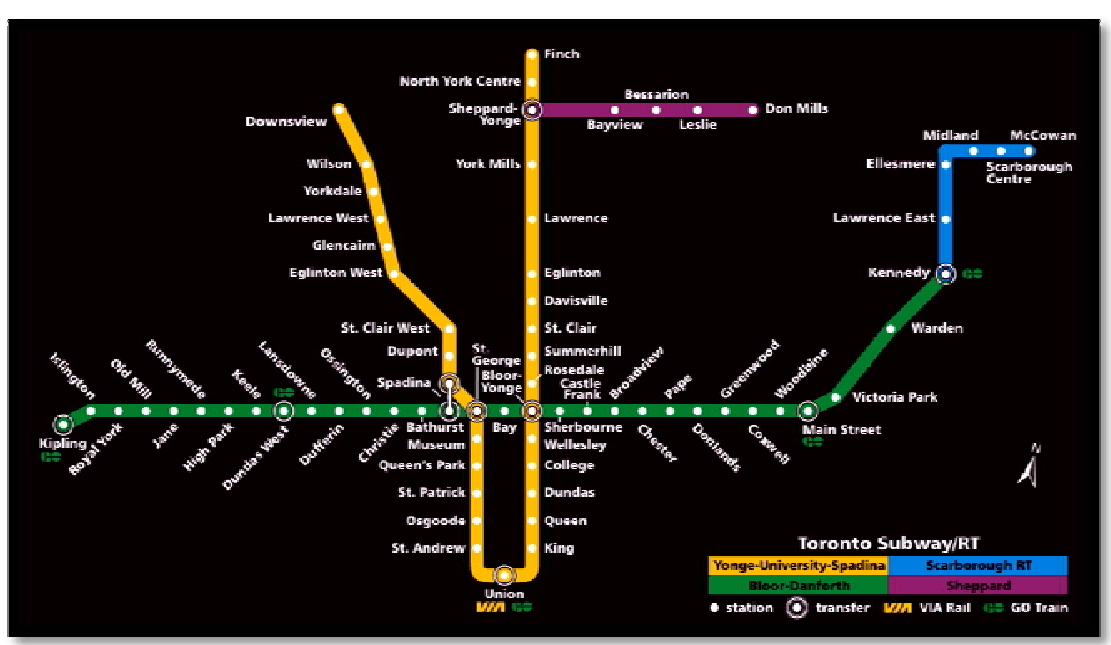

Figure 2.27: Subway lines of Toronto. Similar to 1946 Toronto`s planed rapid transit lines. No significant improvement transit subway, has

remained almost unchanged since 1946 except it is now underground. Therefore the access to a fast, well networked public transportation by the public has been limited and decreasing if one moved from the core of the city towards suburbs. (See figure). The figure shows how the effectiveness of public 
Distribution of trips (pie charts), numbers of trips made, motorized distances travelled, and car ownership in the Greater Toronto Area in 1996 according to place of residence, and also residential densities (see the text for descriptions of Core, Core Ring, etc.)

Core

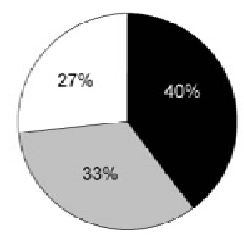

Walk/bicycle

Number of trips per day per person

Motorized distance travelled ( $\mathrm{km}$ )

Households with no car

Residential density (persons per

square kilometre of urbanized area)
Core Ring

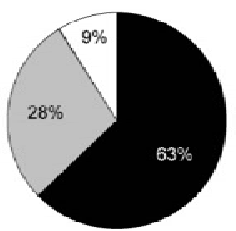

2.23

15.0

$31 \%$

5,900
Inner Suburbs

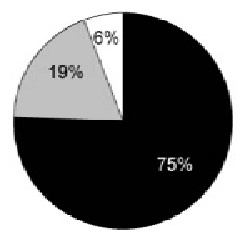

2.26

17.3

$17 \%$

2,900
Outer Suburbs

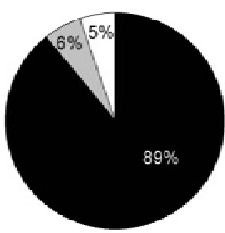

2.51

25.7

$6 \%$

2,000

Source: Transportation Tomorrow Survey, 1996.

Figure 2.28: The share of transportation medium in trips made within Toronto GTA

transport diminishes as one moves from the core of the city towards the suburbs and how cars take over as the main means of transportation.

"The Core is downtown Toronto and the adjacent area, a total of some 18 square kilometres. The Core Ring is a band roughly $8 \mathrm{~km}$ wide around the Core. The Inner Suburbs are a band some $12 \mathrm{~km}$ wide around the Core Ring, mostly the former Cities of Etobicoke, North York, and Scarborough. The Outer Suburbs are the remainder of the GTA; they include the cities of Brampton, Markham, Mississauga, Newmarket, Oshawa, Vaughan, and many other communities." (The Centre for Sustainable Transport, March 1998. Sustainable Transportation Monitor)

Figure 2.30 also shows that typically, as you move further from the city core towards the suburbs, the number of car owners increases because of the lack of public transportation. This indicates that the public transportation network is less effective in those areas and has to be developed since car-based commuting is increasing dramatically and use of public transportation decreasing because of the low density of suburbs See Figure 2.30. Even within the core of the city the car transportation share is very close to the public transportation which confirms that city Toronto is a car based city. For a sustainable environment, public transportation has to have more effect within the borders of a city, including its suburbs. Furthermore, the great distances between the parts of the city should be connected by a lightweight rail system. The longer distances can also be bridged by fast trains that can 
transport people in big numbers between the destinations. Public transportation is a necessity for a sustainable lifestyle and a sustainable environment.

The use of large numbers of cars affects the environment negatively and also that the development and maintenance of roads is very costly. This great cost of billions of dollars can be avoided by creating mixed-use developments that provide work and employment opportunities and thus avoid the need for private commuting. Continuing the same unsustainable pattern in the transportation sector and in car- dependent developments cannot be successful and this unsustainable loop has to be broken.

This has been recognized by the City of Toronto, which plans to improve on existing bicycle lanes and add new ones, slow down traffic and encourage public transportation. A well developed public transportation system network that allows the citizens/occupants of the city to take advantage of public transportation throughout any season and well developed bike routes that provide an opportunity for them to save money and get healthier, should be the major goals of any sustainable city development.

In addition to devising a well developed public transportation system and well developed sustainable neighbourhoods, the constructive use of empty contaminated fields in the city core is also on the city of Toronto's agenda.

\subsection{Sustainable Development in Toronto}

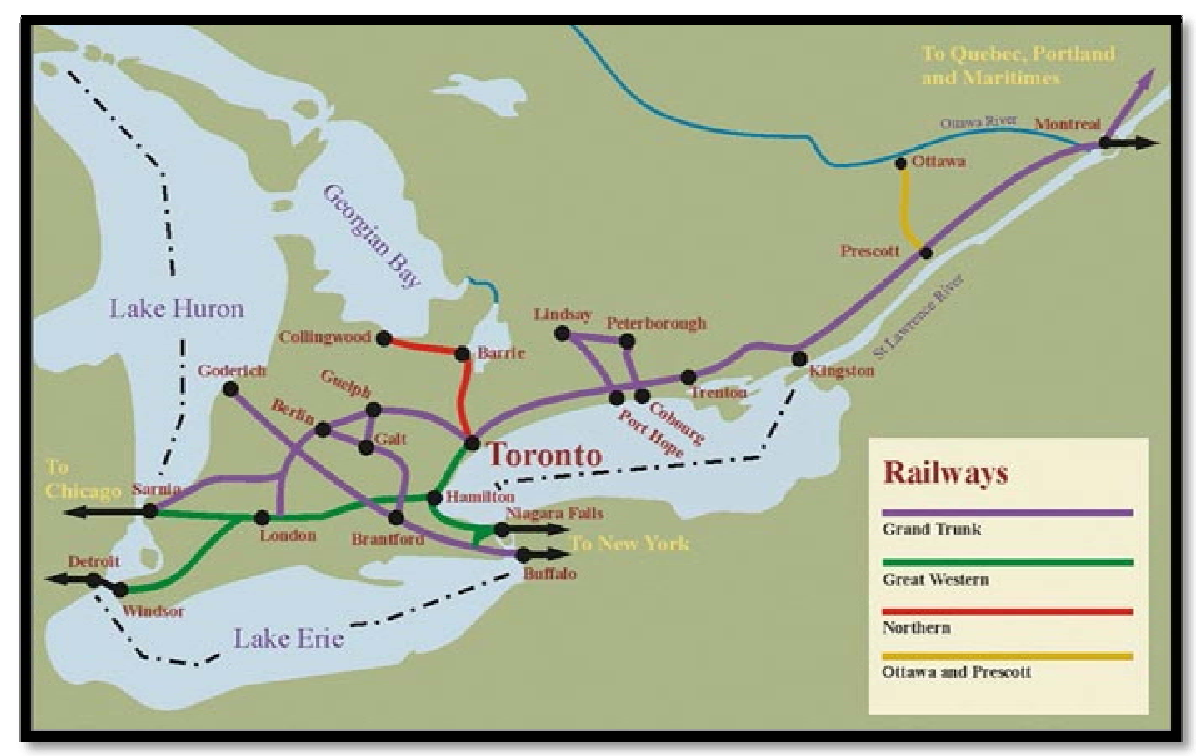

Figure 2.29: Early established railway networks in Ontario
In recent years, awareness of the importance of environmental issues as well as the city's growing population made the empty industrial fields called brownfields a focal point. Toronto's mayor, David Miller, in an interview with Michael 
Lavelle from Going Green for Green said 'It's our goal to take these sites and remediate them and create Jobs" (Ref: "Toronto's Brownfield Goldmining" http://www.building.ca/video/brownfieldgoldmine.asp). The City of Toronto, based on its environmental politics, encourages development plans for contaminated sites and already big sustainable developments gives also an opportunity to clean Toronto waterfront and other contaminated sites and convert them into sustainable desired urban places.

Historically, Toronto's industrial development started with the implementation of railways. In 1851, Toronto began railway construction on Front Street to connect Toronto to other regions of the colony; it took two years to complete the line between Toronto and Lake Simcoe. This was the first step in creating a powerful connection to the North. In 1855, an east-west rail-line opened, linking Toronto to Montreal, Quebec City and the Atlantic colonies. Toronto was turning

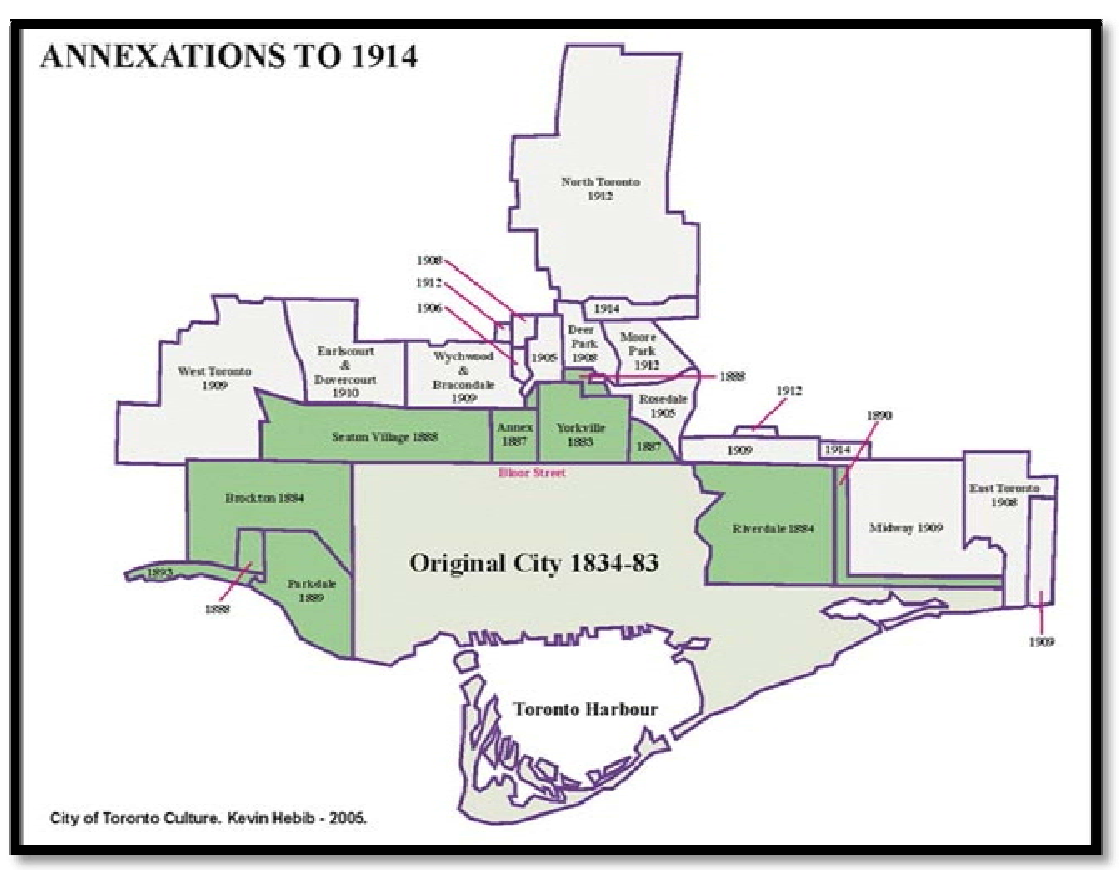

Figure 2.30: Old city Toronto into a railway hub along with Montreal and Hamilton. New factories used coal-fired steam machines and therefore it was convenient to locate industries along the railway lines so that they could take advantage of the distribution of coal. Coal was imported by ship from Pennsylvania and therefore most industries that used steam power tended to be located on Toronto's harbourfront or along the

railways to reduce transportation costs.

Toronto's waterfront was a very active place even before the railways arrived since all the goods transported on ships arrived there and they were then distributed from that point to the rest of the city and beyond. Between the 1850s and the 1920s, industrial development made it a busy and crowded place and so it expanded southwards. The harbour was filled in to gain more land for industries and today's lakeshore was created. (For example, as a result of these lake fill operations, the Fort York shoreline shifted about 900 meters to the south.) 


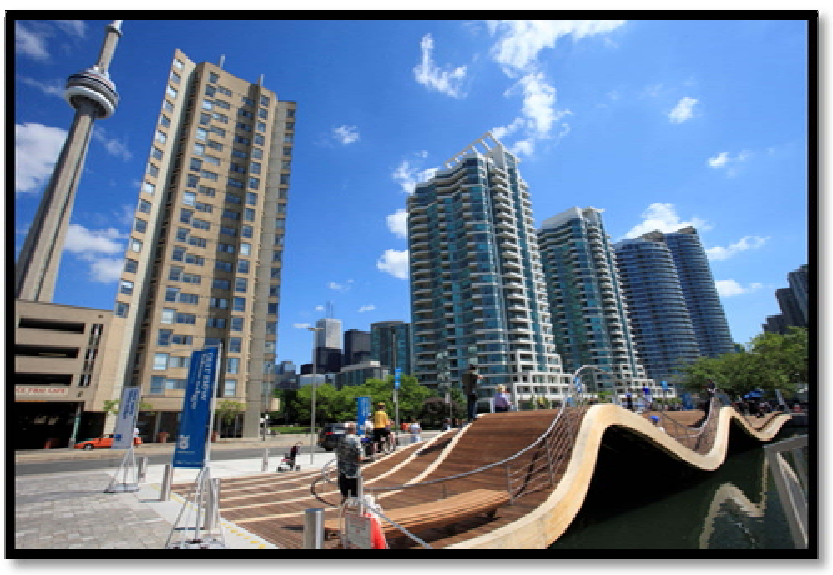

Figure 2.30: Toronto Waterfront today
After the waterfront became very active in the 1850s, industry destroyed its attractiveness and contaminated its fields and the environment. Although an esplanade was constructed along the waterfront to restore Toronto's attractive shoreline it was not successful at keeping industry away from the waterfront. The wealthy residents of Toronto

moved north of an along Jarvis Street because of unhealthy environmental conditions created by waterfronts industries. There have been commercial, residential and industrial zones created early in the history of Toronto. (Retrieved from the website, http://www.toronto.ca/culture/history/history-industrializing-city.htm, December 2009)

Some of these contaminated fields still remain along the waterfront and some have been occupied by hotels, restaurants and condominiums. However, some of the industries, such as the sugar refining plant on the waterfront are still active. Toronto has an active waterfront remediation plan to regenerate brownfields along waterfront that is partially realized.

But Toronto's waterfront is not the only industrial area of Toronto with brownfields. In the past the conversion of used trade trails to the north of Toronto into streets led to businesses gathering along the streets to the north along Yonge and Bay streets, as well as along the railways towards the north and along the major east-west rail way of the waterfront. This is how the shape of the city of old Toronto was established.

There is now an opportunity to revitalize contaminated brownfields located within the city and some projects have been realized since cleaning up contaminated brownfields is much easier today than it was in the past. The contaminated soil can be cleaned on site after it is run through a conveyer belt and heated and the chemical substances practically separated from the soil. The cleaning also utilizes chemicals that will clean the soil from the toxic substances and put it back onto the existing site. Any biological toxins are treated by biological cleaning methods until they dissolve and no longer pose a threat to the environment. (Retrieved from the website, http://www.ehow.com/way 5394437 contaminated-soil-treatments.html, December 2009) 
Ontario also made legislative changes between October 2004 and October 2005, adding environmental legislation that requires environmental reports for new site developments. The report specifically addresses environmentally contaminant hazardous materials and forces developers to comply with legislation by treating contaminated materials. (Marcia Luke, From Brown into Green, http://www.newinhomes.com/articles/article.jsp?article=306, December 2009)

The city of Toronto encourages development plans for contaminated sites based on its environmental policies and already big sustainable developments have given opportunities to clean Toronto's waterfront and other contaminated sites and convert them into sustainable and desirable urban places.

The sustainable developments call for new principles in contrast to car-based developments. These principles will change urban design and planning. Smart growth is one collection of these principles that is widely accepted as a new path towards achieving sustainability in urban design.

\subsubsection{Ontario Government Smart growth and urban design elements}

"Smart growth" promotes the creation of sustainable communities based on the integrated application of sustainable principles.

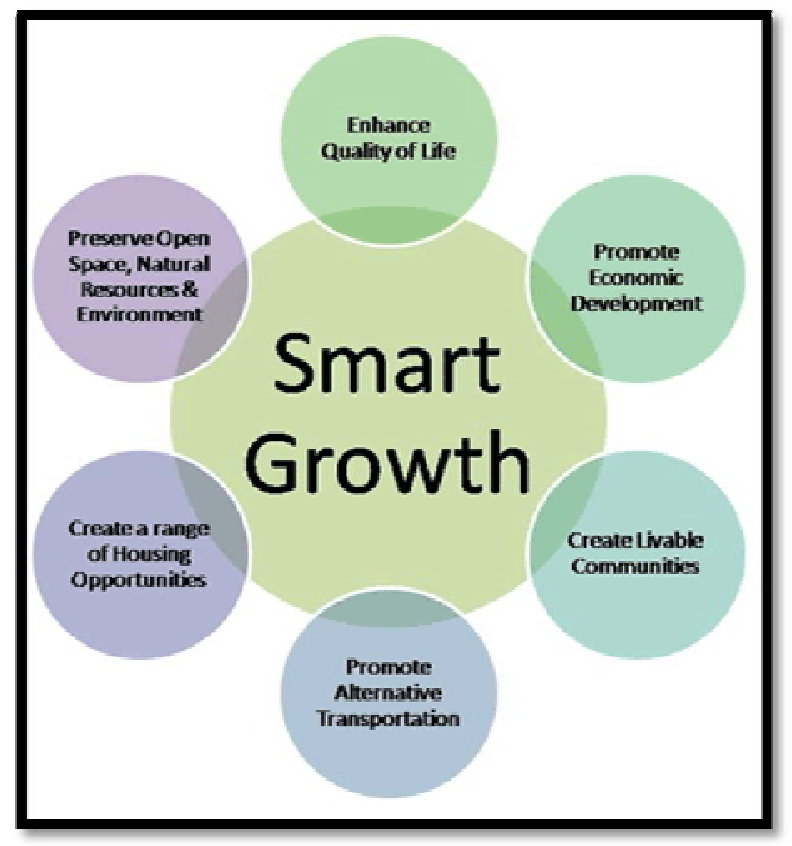

Figure 2.31: Smart Growth components
These are:

1. Mixed land uses. Each neighbourhood has a mixture of homes, retail, business, and recreational opportunities.

2. The building of well-designed compact neighbourhoods. Residents can choose to live, work, shop and play in close proximity. People can easily access daily activities, transit is viable, and local businesses are supported.

3. The providing of a variety of transportation options. Neighbourhoods are attractive and have safe infrastructures for walking, cycling and transit, in addition to driving. 
4. The creation of diverse housing opportunities. People in different family types, life stages and income levels can afford a home in the neighbourhood of their choice.

5. The encouragement of growth in existing communities. Investments in infrastructure (such as roads) and amenities (such as schools) must be used efficiently, and developments should not take up new land.

6. The preservation of open spaces, natural beauty, and environmentally sensitive areas. Developments respect natural landscape features and have higher aesthetic, environmental, and financial value.

7. The protection and enhancement of agricultural lands. A secure and productive land base, such as BC's Agricultural Land Reserve, provides food security, employment, and habitat, and is maintained as an urban containment boundary.

8. The utilization of smarter and cheaper infrastructure and green buildings. Green buildings and other systems can save both money and the environment in the long run.

9. The fostering of a unique neighbourhood identity. Each community is unique, vibrant, diverse, and inclusive.

10. Nurture-engaged citizens. Places belong to those who live, work, and play there. Engaged citizens participate in community life and decision-making.

( Retrieved from the website of Smart growth BC, http://www.smartgrowth.bc.ca/Default.aspx?tabid=133Smart, December 2009)

Smart growth has integrated sustainable principles for applications within the existing communities. This urban planning method is an attractive sustainable alternative to conventional development and suggests one way of converting brownfields to sustainable places. 


\subsubsection{Public Spaces}

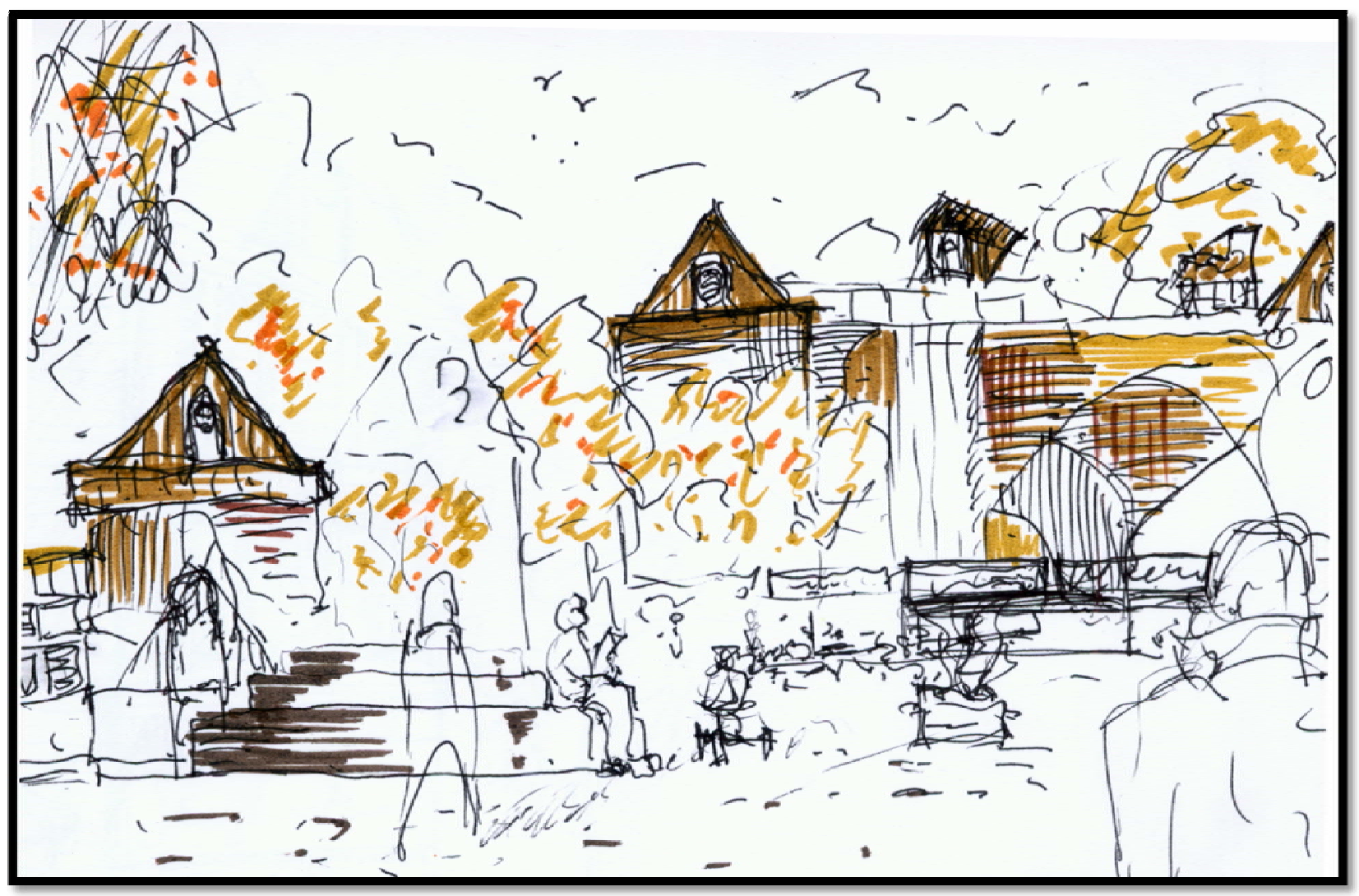

Figure 2.32: An imaginative view of an urban space

One major urban planning variable that has to have particular attention paid to it to achieve sustainability is public space. Urban public space should be seen as a part of sustaining places, since most of the public social interaction takes place in such spaces. Urban space bonds communities and gives a sense of belonging. Some places we just visit or pass through, but they make us want to stay there and give us a feeling of well-being. Some places we just visit and do not intend to stay since we feel something is missing in those places. Diverse architecture, people-friendly places, human activity, human scale in architecture, landscaping and, most importantly, places that are created with human comfort in mind are criteria for the most successful places. These important elements of architecture and urban planning are the keystones for the success of a public place and its sustainability. These places will be the ones that pull pedestrians in and form a base for social activity and interaction. There are great examples of cities in Europe such as Rome, Venice and Istanbul where history, architecture and urban planning come together to form a very desirable city that emphasizes the importance of the public realm. Some sections of these cities, such as the closed bazaar in Istanbul, have remained focal points of tourist and domestic interest over the years and even 
centuries. These places are where most social interaction takes place and where, often, great architectural landmarks were built. However, small places and small urban spaces are very important as well. The social interaction of the immediate social community where a sense of belonging is created is a building stone of a healthy city with a solid and sustainable community.

\subsubsection{Existing Pedestrian Zones in Toronto}

Another element of sustainable places is the pedestrian

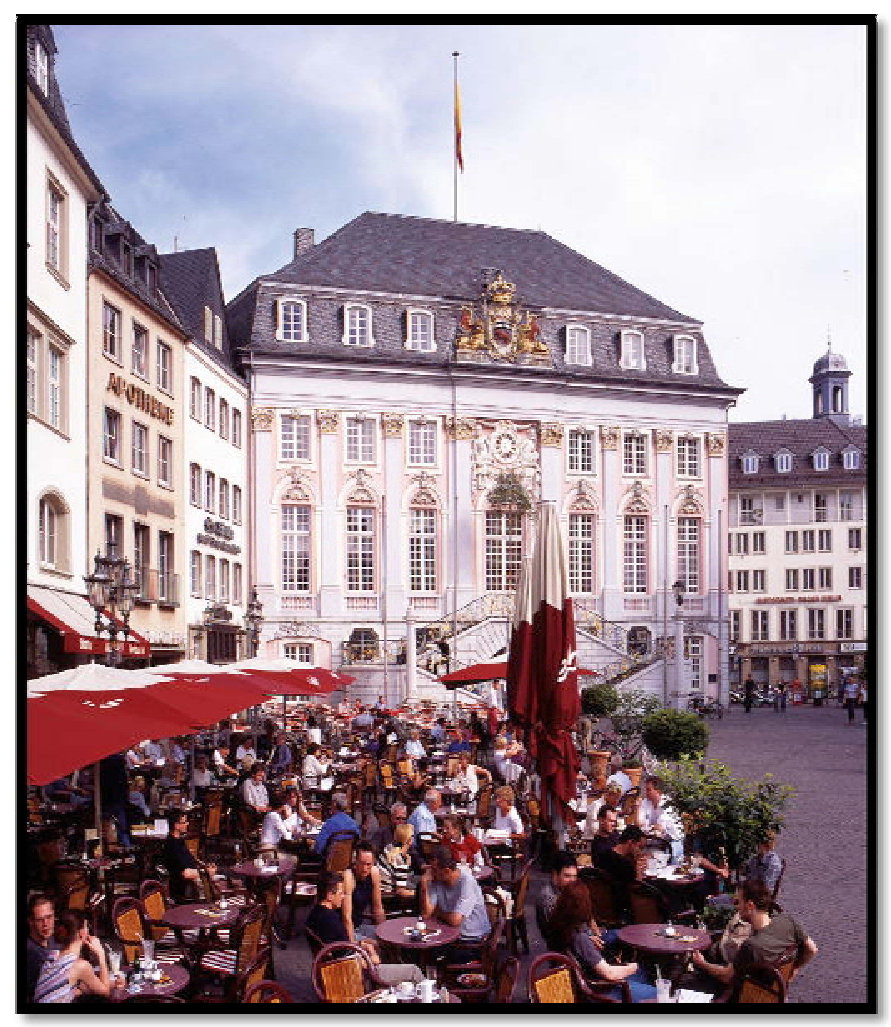

Figure 2.33: The city hall and urban space Bonn, Germany zone that allows people to walk freely without being threatened by moving cars. One other benefit of having this type of development is that it promotes social interaction and bonding with other people. Many countries have adapted pedestrian zones for human interaction without being disturbed by cars and pollution. Germany, France, the Netherlands and many more countries have made pedestrian zones a part of their urban planning. Reference pictures are of

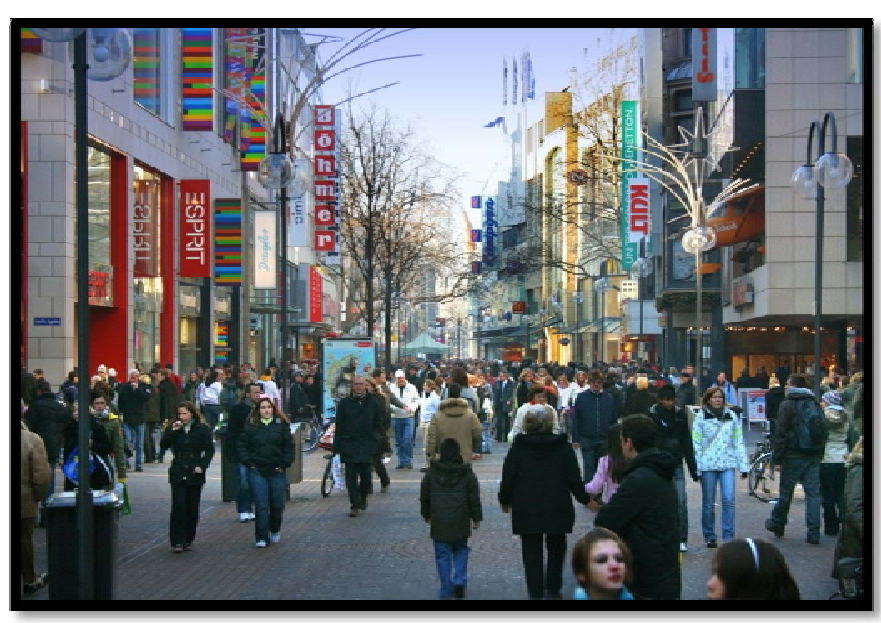

Figure 2.34: A car-free pedestrian zone in the High Street, Cologne, Germany pedestrian zones; some allow bicycles and roller blades to pass through, others only pedestrians. In Canada, Vancouver, Ottawa and Quebec City are just some of the cities that have adopted pedestrian zones as a part of their urban planning and design. Toronto has a few pedestrian zones that have mostly become amusement centres, such as the Toronto Islands, Harbourfront, The Beaches boardwalk and Ontario Place, the latter only accessible by paying a fee. 


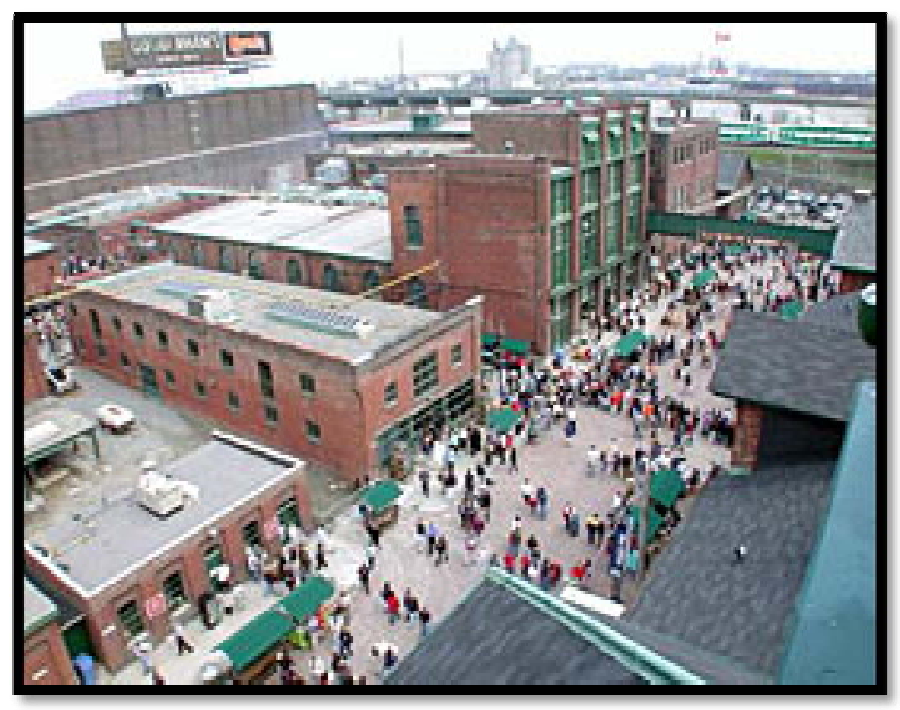

Figure 2.35: Distillery District Toronto
Another example of Toronto's pedestrian zones is found in the Distillery District. After the historic company Gooderham \& Worts sent their last shipment of alcohol in 1990, the new owners of the site decided to renovate and build the Distillery District in 2001. This historic district of Toronto has been saved from new condominium developments and turned into pedestrian zones that truly allow everyone free access. Pedestrian zones also encourage human activity and can be created along shopping strips within a district, resulting in

increased economic activity. Attention paid to the architecture and detail would make the public space even more welcoming.

If we look at the great public spaces such as St Mark's Square in Italy we see the influence of architecture on public spaces. Public spaces are created by the architecture defining the edge; this is what creates an urban space and gives it a character that influences human emotions and attracts people to it. Human scale is important. Modern architecture and new $21^{\text {st }}$ century cities are going vertical and very tall, and large buildings placed in cities can make people feel little and unimportant. However, with attention to detail at eye level, where human perception of the space is most focused, that blandness and overpowering scale can be corrected and the surrounding architecture can become more attractive and make the public spaces

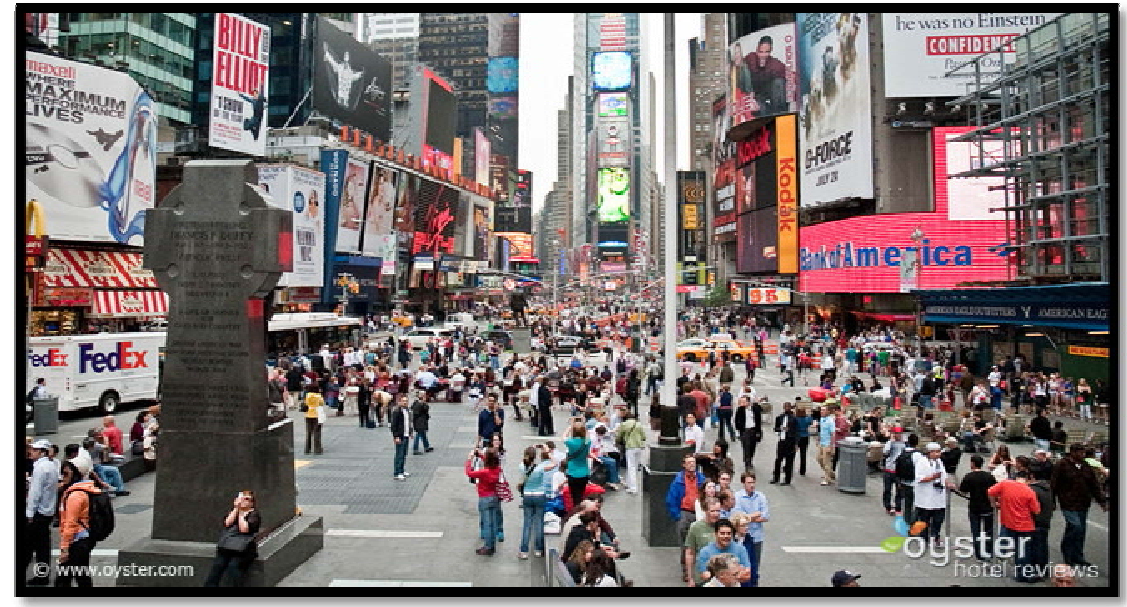

Figure 2. 36: Now a pedestrian zone: Times Square in New York City, NY, USA

more attractive themselves. 
The value of that urban space will also increase, making for economic interaction with the rest of the city, in addition to social interaction. Older cities and familiar places that we would like to visit again and again are the best evidence of this.

\subsubsection{Bicycle Paths}

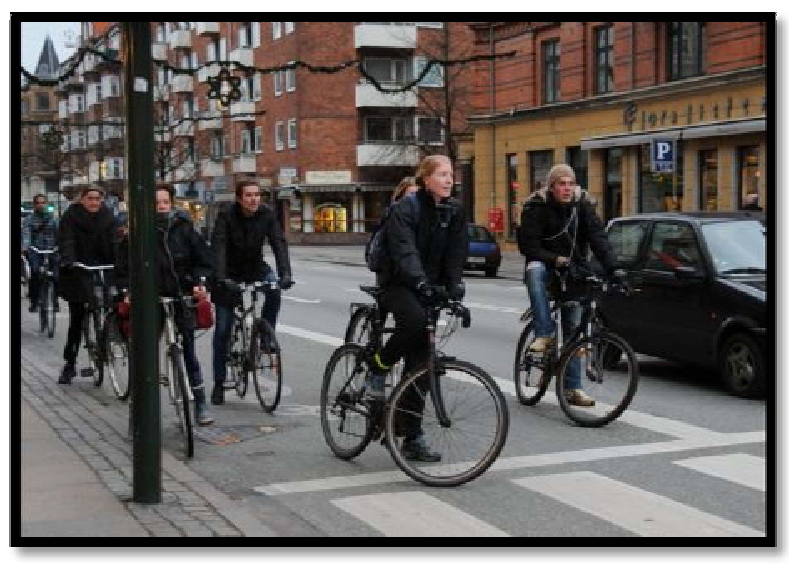

Pedestrian zones can allow for the development and use of alternative vehicles such as bicycles. The development of bicycle routes and networking them together not only promotes healthy activity but at the same time provides cheap alternative transportation that effectively reduces harmful gas emissions.

Figure 2.37: A common picture: Bicycle riders in Copenhagen, Denmark

\subsubsection{Zoning Requirements: Parking}

Parking requirements are determined by the zoning by-laws of the city. Developers have little choice but to follow zoning by-laws with little flexibility for sustainable development, or to appeal it and wait until a lengthy and possibly costly process has been resolved. For instance, if one wanted to develop a sustainable site, such as a pedestrian only or a car-free zone, there would be no way of reducing the parking spots without going through the process of getting permission from the city. This of course becomes one of the obstacles for developing sustainable sites.

On-grade parking within the city or elsewhere are problematic since the space cannot be used for anything else during the day and, at night, these spots are mostly empty so that no human interaction takes place. Cars can be brought underground and the parking lots on grade can be made more attractive places. Although underground parking is more expensive, its development for long-term benefits for a better city cannot be over-emphasized. Car parking along the streets can be very useful and in some cases is desirable. Parked cars provide a barrier between pedestrians and fast-moving cars, giving the pedestrians peace of mind and protection as well. 
In addition, the parked cars slow down fast-moving traffic, making for a better environment for bicyclists and pedestrians.

\subsubsection{Neighbourhood development and LEED}

To consider the development of much more attractive and sustainable neighbourhoods, the United States Green Building Council has started a pilot program for neighbourhoods named LEED (The Leadership in Energy and Environmental Design). It is a rating system that was developed by integrating principles of sustainability and smart growth urban planning and is specifically designed to rate this kind of development. This rating system, like the sustainable building rating system LEED, will be adhered to by the Canadian Green Building Council for developments throughout Canada. The difference between the American LEED rating and certification system and Canadian one is that the Canadian LEED certification is tailored specifically to the Canadian climate and environment. (Canadian Green Building Council). "What is LEED?" (Retrieved from http://www.cagbc.org/leed/what/index.php, November 2009)

LEED is currently the recognized certification system within the building industry in North America. It has been criticized for not really addressing the issue of sustainability and focusing more on the energy savings of a building. In fact, the choice of materials is not a clear-cut issue. For instance, LEED does not suggest the use of alternative sustainable materials. There are no sustainable material classifications. Moreover, leather has been a popular natural material but manufacturing and tanning leather is a majorly unsustainable process since toxic gases are emitted during the tanning process. In addition, LEED for buildings has not been integrating mixed-use building developments and single-use buildings have been rated as energy efficient and sustainable. Also, LEED has not been addressing questions of commuting to these buildings nor their energy efficiency during times when they are empty. The new LEED neighbourhood program targets these deficiencies and the LEED program is improving as experience is gained along the way. (Hasek G. (June $30^{\text {th }}, 2009$ ). LEED Buildings Not Always More Efficient. Green lodging News.( Retrieved from the web site: http://greenlodgingnews.blogspot.com/2009/06/research-leed-buildings-not-a/ways-more.html, December 2009)

Despite these criticisms, LEED is one benchmark in the production of energy- efficient buildings and in the creation of a better environment. 


\subsection{Sustainable developments on brownfields in Toronto}

Some recent developments in Toronto are environmentally conscious and take advantage of the brownfields' potential. These developments found great support from the City of Toronto. There is, for instance, the Build Green/Waterfront program, which wants to convert existing brownfields to an acceptable mixed-use integrated housing and business development. In addition, these developments take advantage of public transportation and aim to create a walkable live/work environment. (Marcia Luke. From Brown to Green. Retrieved from the website: http://www.newinhomes.com/articles/article.jsp?article=306, August 2009)

One such development is the West Don Lands development that has been accepted by the public as an exciting project and is a part of a larger development called the Toronto Waterfront Development that targets the development of abandoned industrial areas alongToronto Harbour. 


\subsubsection{Case Study: West Don Lands}

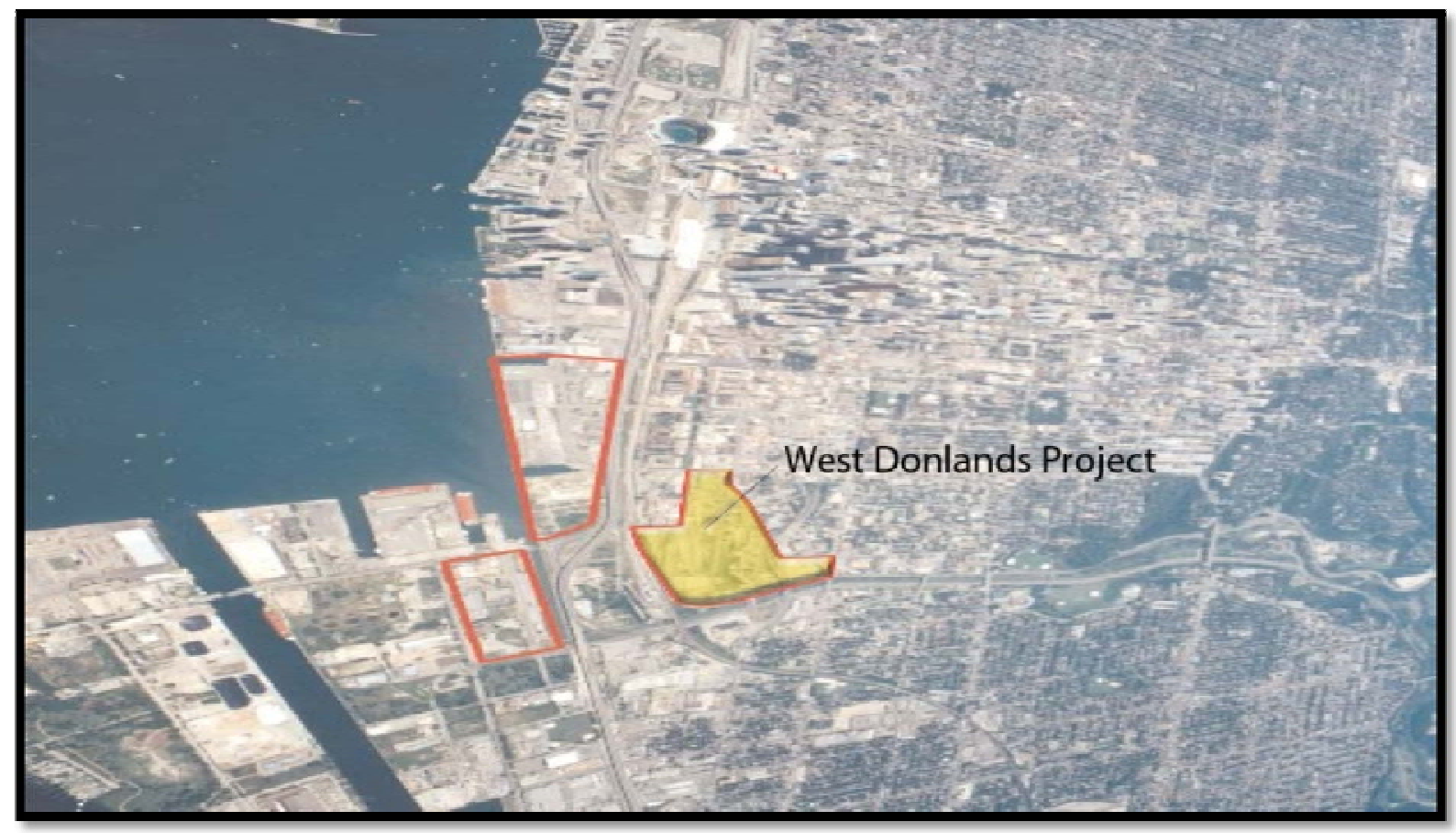

Figure 2. 38: Overall development plan. West Donlands Project shown with other parts of the Toronto Waterfront Projects .

The West Don Lands is a mostly government-owned 80 -acre area that runs from Parliament Street in the west to the Don River in the east, and from King Street down to the rail corridor.

The area is within walking distance of downtown. It is also in close proximity to the historical Distillery District that has been converted into a pedestrian zone. West Don Lands has good connections to the existing St. Lawrence and Corktown neighbourhoods.

Key Elements of the West Don Lands Project are:- 23 acres of parks and public spaces including 18-acre Don River Park

- Public transit within a five-minute walk of all residences

- 5,800 residential units, including 1,200 units of affordable rental housing

- One-million square feet of employment space

- Pedestrian \& cycling connections within neighbourhood and to city

- Elementary school

- Recreation centre

- Two childcare centres

(Ref. : www.Torontowaterfront.ca, December 2009) 


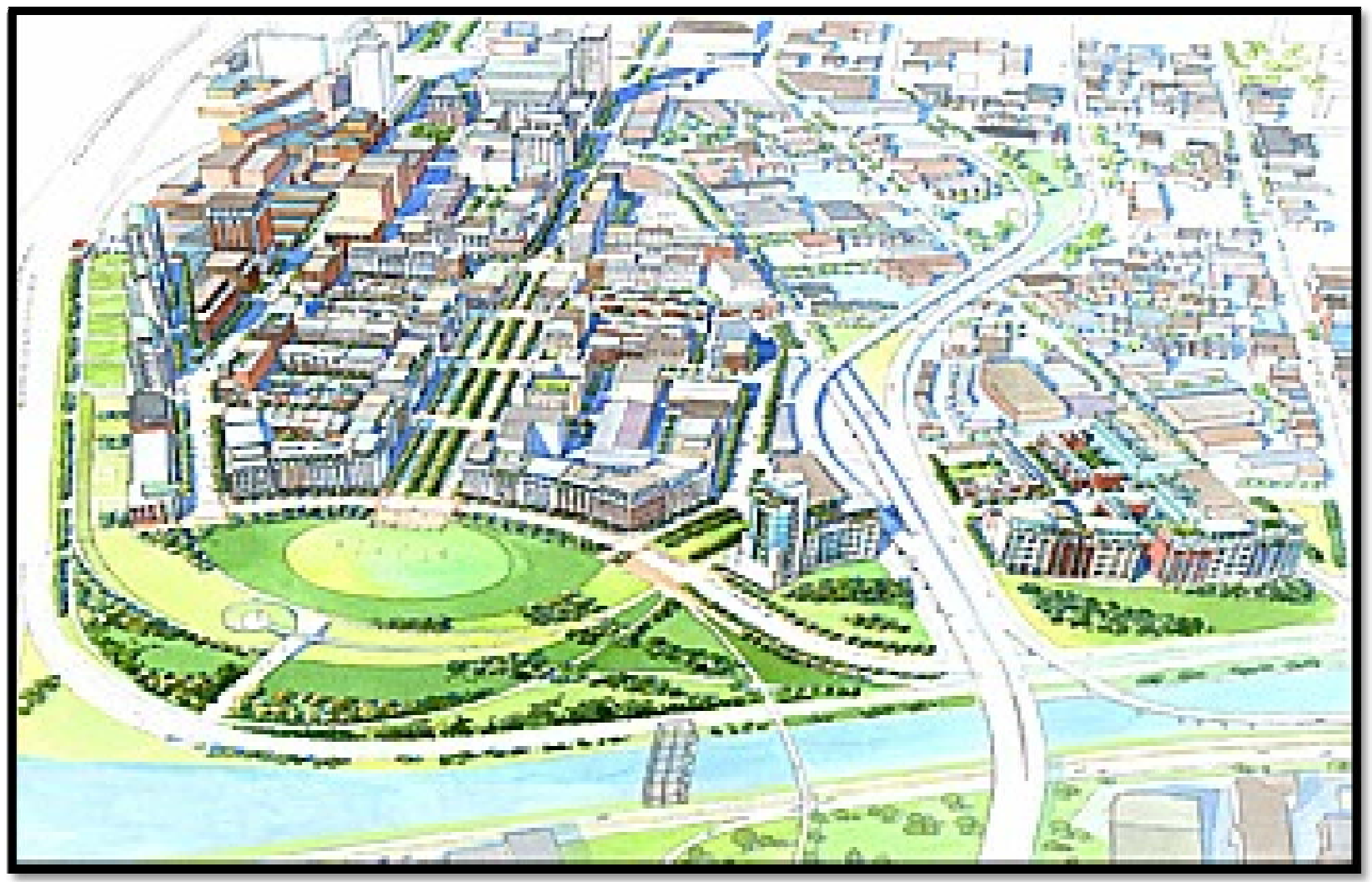

Figure 2. 39: Overall development plan West Don Lands

Costs:

- Overall development - estimated $\$ 231$ million over 15 to 20 years, including:

- Phase one infrastructure - \$4 million

- Berm - \$8 million

- Don River Park - \$17.6 million

(Retrieved from the website: http://www.waterfrontoronto.ca/dbdocs//447b5c381a5de.pdf, December 2009)

The Toronto waterfront project is a very ambitious project, similar to the Greenwich project in the U.K., that targets the industrial harbour zones near the Thames River in London. 


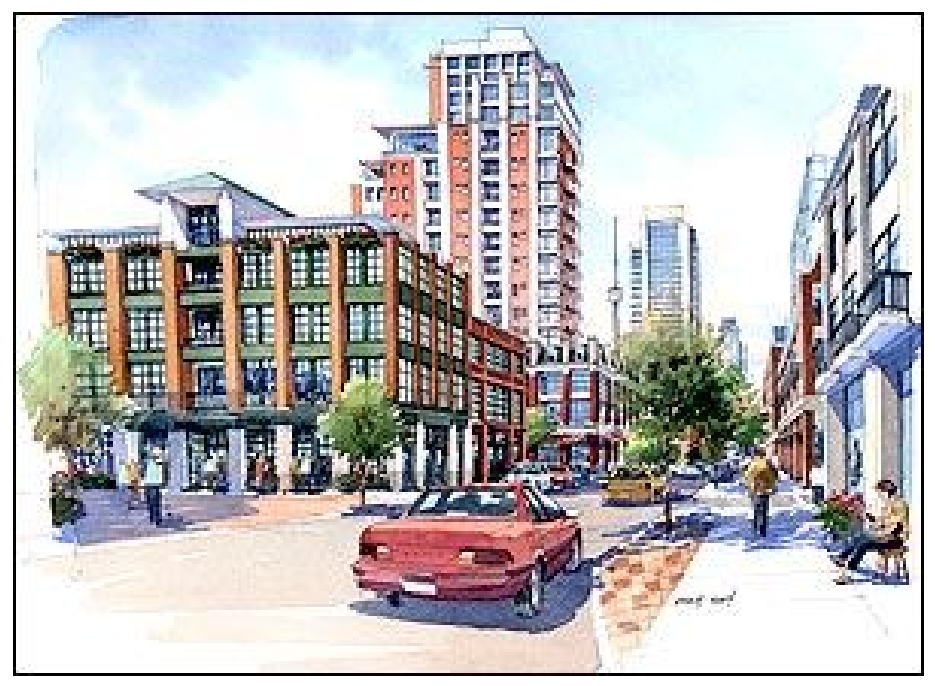

Figure 2. 40: An imaginative view towards west from the new development West Don Lands, Toronto, ON.
The West Don Lands project is infilling the empty and rehabilitated industrial areas of the city of Toronto and adjoining areas to create a more attractive mixed-use place. As the project is still under development some changes may occur; however, this kind of large development is also more complicated in terms of planning and constructing. A project that big will have also immense impact on its surroundings. The development tries to integrate new urban guidelines and

environmentally friendly elements of urban planning such as bicycle access and pedestrian walkways.

The development is also aiming for LEED Gold certification that is administrated by the Canadian Green Building Council. One other environmentally friendly and sustainable aspect is that providing energy-efficient district heating for the development will decrease construction costs and increase the air quality and energy efficiency.

Converting bownfields into attractive and sustainable communities must be complemented with the creation of suitable public realms. This is a major consideration in any type of community development and must be integrated in all land developments as a major part of the design.

\subsubsection{Case Study: 31 Broadcast Lane, Toronto Ontario}

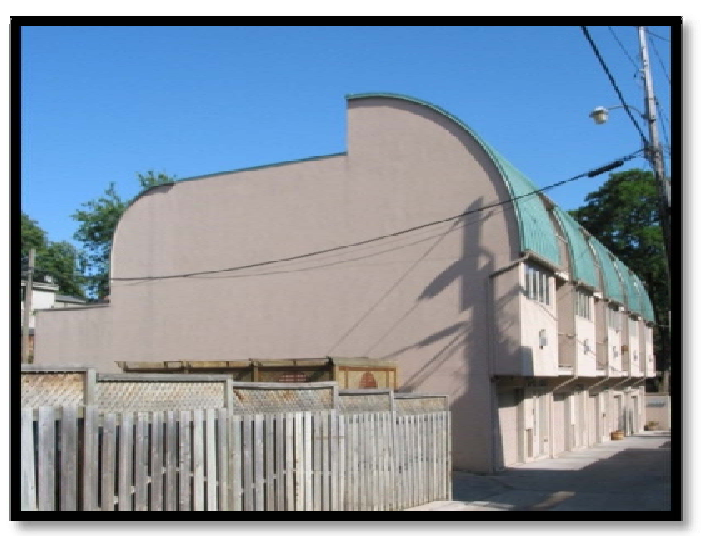

Figure 2.41: A view of Broadcast Lane development
This project is important since a small but intensive housing development has been established on brownfields that have had automotive and petroleum-based contaminants like automotive oils etc cleaned up. The site has been cleared of existing oil tanks and backfilled. It is a small site with an area of 800 sq. m. (0.08hectares). The residential 


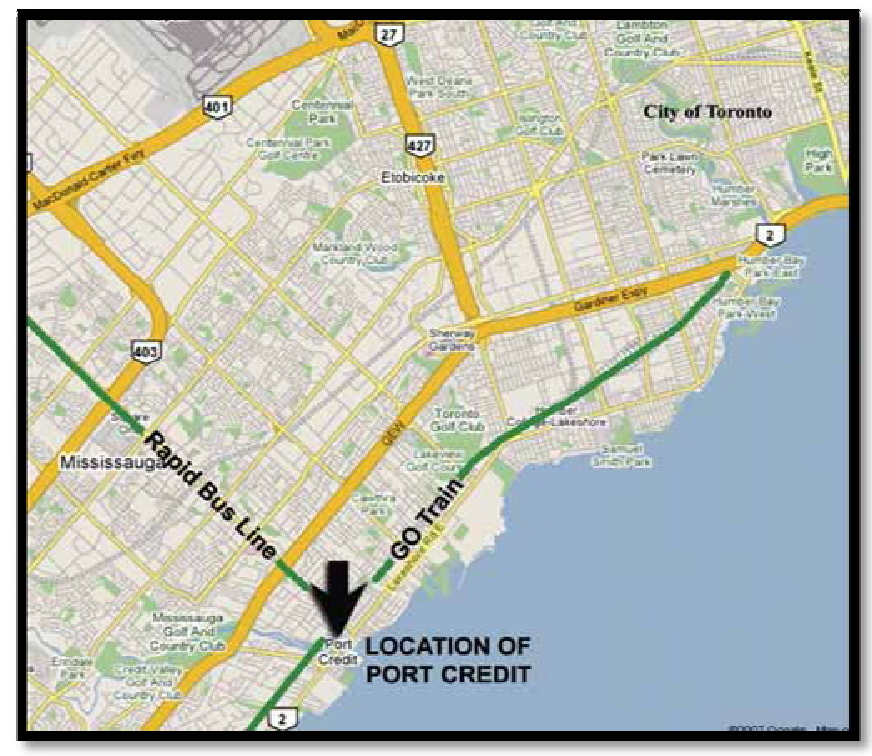

Figure 2.42: Location of the site

development was designed by Studio Linea Architects and developed by Royal Dundas Developments. The success of the project was a result of public participation and support as it went through minor variations and site plan approval. The erected housing is threestory residential developments that are highly efficient and competitive in price.

These residential buildings are designed as open-plan layouts in harmony with the existing neighbourhood. The development also offers a better and safer environment that gives value to the surroundings and to the environment.

\subsubsection{Case Study: Port Credit Village Mississauga (GTA), Ontario}

One transit-oriented, sustainable development in the GTA is Port Credit Village. It is a five-minute walk from the GO transit station. It is also in close proximity to a large express bus terminus. The regional transportation system, "GO Transit", is a very popular rail line, established in 1967 by the province of Ontario that takes people to downtown Toronto $b$ in a short time.

It was also a major decision of the developers (FRAM/Stokker) to choose this site. There were major obstacles on the way since the majority of the committee was not happy with the proposed high-density scheme, and as a result of this opposition there was an Ontario Municipal Board hearing. The OMB decided that the building heights and density had to be adjusted. After collaborative work with the community, the project took on its present-day form. Another important point is that this big settlement has been developed on brownfields which had to have contaminated materials cleaned up from them. Most of these materials were fly-ash or heavy metals, and in addition there was a leaking gas tank. 
The project is divided into two phases. Phase I is largely a residential development. Phase II is more of a mixed-use development that is expected to include a pedestrian-oriented environment and to further extend retail frontage. The project's Phase I has an approximately 10.5 hectare area holding 410 units in total: 225 condominium apartments, 167 townhouses ranging from $126 \mathrm{~m}^{2}$ to $600 \mathrm{~m}^{2}$ with an average size of $233 \mathrm{~m}^{2}$. In addition, approximately 1,400 $\mathrm{m}^{2}$ of office and $3,700 \mathrm{~m}^{2}$ of commercial mixed retail area has been provided for the development. With a density of 39 units per hectare and average building height of six to three

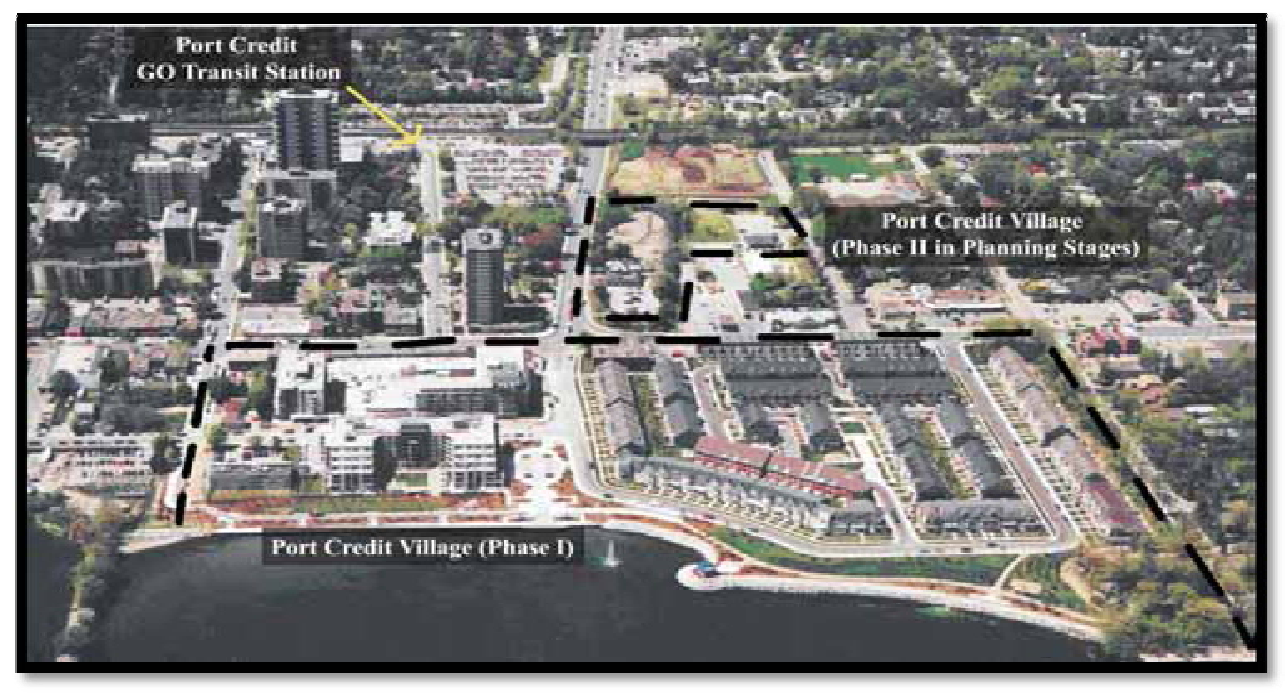

Figure 2.43: A phasing plan of the Port Credit Village project, Mississauga, Ontario stories, the buildings are not too high nor too crowded but within the human scale range. Although on-site parking is established, the developer did not put any parking at the waterfront, in order to leave it undisturbed. Instead, they provided underground parking to satisfy zoning requirements. The redevelopment of this area brings benefits to its immediate surroundings and has influenced the area in a positive way.

The redevelopment of the waterfront area has allowed the public to be able to access the waterfront. It has linked the existing area to the new development and also to the retail and commercial areas, thereby avoiding the necessity of commuting. Also, 18 live/work units provide a different lifestyle to go along with the mixed-use development. The public square of the development encourages social interaction and gathering. Also, the development paid attention to emphasizing the architectural and urban planning elements of the historical setting. 
The commitment of the developer and collaboration with the community has shown that more sustainable and meaningful developments can be achieved. The residents of the new development enjoy amenities and benefits from the surrounding setting and it in turn provides benefits to the surrounding community.

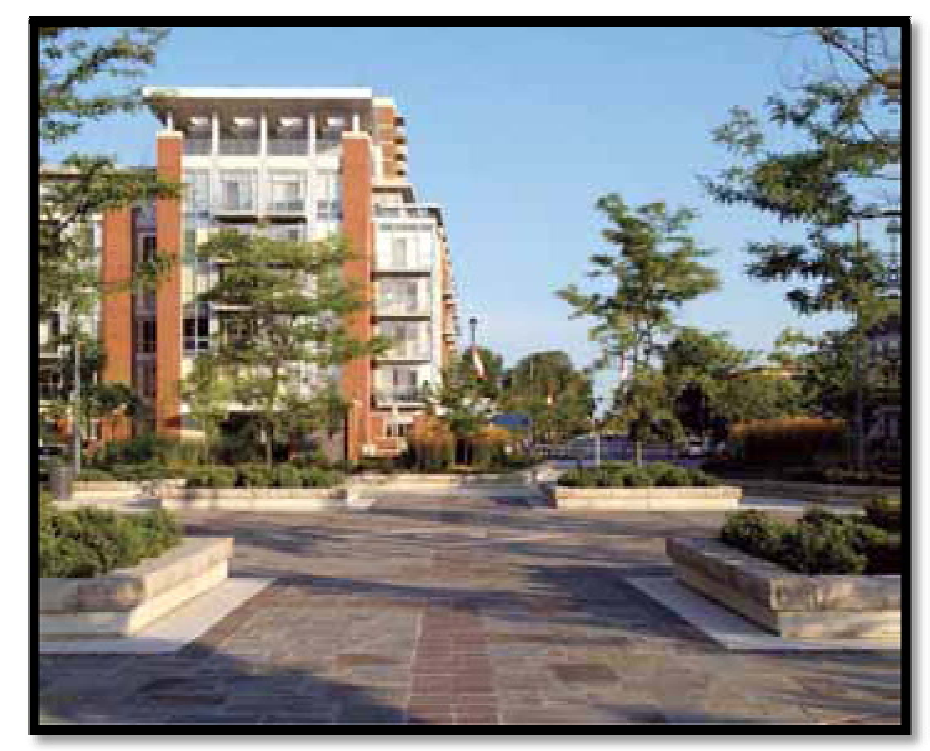

Figure 2. 44: A View from the development

\subsection{Chapter Summary}

Research shows that our fossil fuel-based energy system is threatening our environment, our very existence. The developed technologies and goods and any materials we produce have an effect on our environment. The increasing energy demand of the world shows that the negative impact of our fossil fuel-based energy system will continue and the greenhouse effect causing gas emissions will continue to rise and that these emissions cannot be eliminated. The only way to reduce them is to achieve a sustainable lifestyle on a very large scale. Architect and urban planner Jaime Lerner says, "City is not the problem, it is the solution..to climate change." (Retrived from the website TED.com: http://www.ted.com/talks/jaime lerner sings of the city.html, December 2009)

Therefore, sustainable communities are of paramount importance. Also, the settings of sustainable communities will determine the success of sustainability itself. Therefore, alternative urban planning methods like smart growth that can reduce private commuting are very important. A mixed-use environment that is walkable and provides working/living/shopping and entertaining urban sites is needed to avoid commuting.

All case studies that have been presented here show that there are large and small environmentally conscious developments spreading around the world. 
In Toronto, many of the developments target the abandoned industrial fields called brownfields. They want to clean up the environmentally hazardous materials from the sites and at the same time be able to develop better, more sustainable neighbourhoods. The City of Toronto is aware of the environmental issues and is developing programs and specific standards, such as the Green Development Standards, that are comparable to LEED standards, but in some areas, such as tree protection, are much better.

It has been clear that urban design is a big factor in sustainability. Creating sustainable buildings and even communities alone is not sufficient. Urban environments should be established with desirable urban elements, such as urban spaces, pedestrian zones, bicycle paths, walkable streets, landmarks, vegetation, architectural detail and human scale, etc. In addition, if a development is to be sustainable, it should be near the public transportation network. Many of these most sustainable developments that will provide an enjoyable alternative lifestyle are capable of changing the structure of the city. 


\section{SUSTAINABLE URBAN IMPLANTS}

\section{Introduction}

A sustainable urban implant is a core created by integrating sustainable architecture and urban planning and design with regenerated brownfields. A sustainable urban implant has a positive impact on the environment. The most effective places to plant these types of sustainable urban developments into are existing suburban communities near abandoned or under-used areas such as brownfields and along public transportation networks. Such development should comprise all key characteristics of sustainable urban planning and architecture on a human scale with human comfort and social interaction in mind.

In order to spread a sustainable lifestyle and prompt a change to a better alternative system, sustainable communities must become part of the life of their cities. While sustainable communities can be found in many places, they can only be sustained as long as the community is able and is willing to support their success. Also, their viability is largely dependent on connections provided by a well designed transit system.

Based on all the knowledge gained about sustainable communities and from sustainable neighbourhood development case studies, it is concluded that sustainable urban implants should have the following characteristics:

- $\quad$ They must create urban spaces and establish a public realm that will support and promote intensive social interaction.

- $\quad$ They must provide alternative energy sources and technologies.

- $\quad$ They must be made memorable by the creation of landmarks.

- $\quad$ They must satisfy the needs of the surrounding communities as well.

- $\quad$ They must make human comfort and satisfaction priorities. 


\subsubsection{Where sustainable urban implants can be integrated in Toronto}

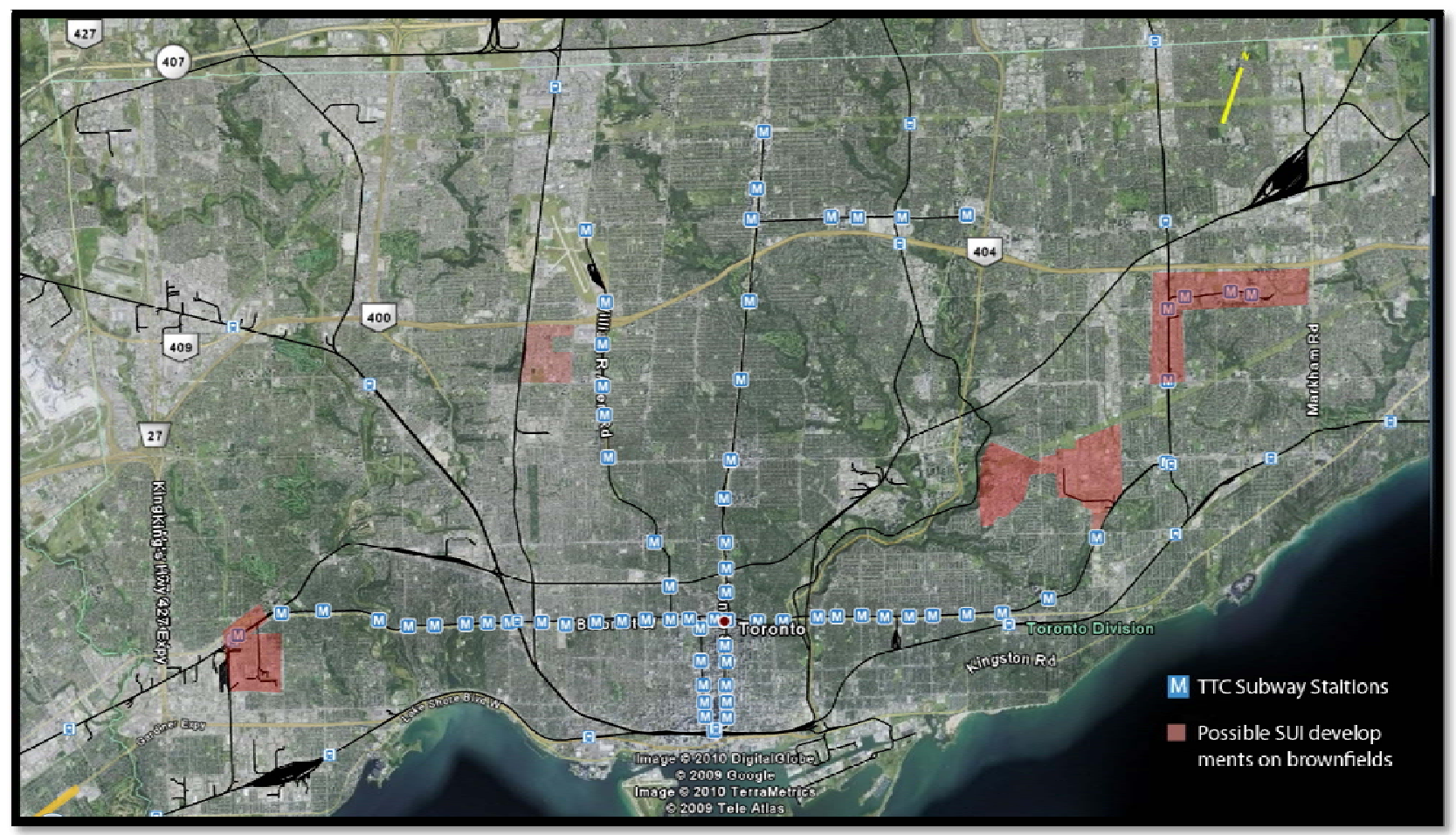

Figure 3.1 The map shows possible Sustainable Urban Implant developments along the subway lines on brownfields

Toronto provides many opportunities to insert sustainable urban implants. When first trying to establish successful urban implants, it is necessary to find places where public transportation crosses through or is adjacent to brownfields, providing an opportunity to develop mixed-use urban spaces and densities. Such locations would help many small industrial and commercial developments to maintain their economic status. These types of empty sites are already being developed by design-build companies who convert them to residential townhouses or small row-house type of developments in the suburbs, such as the one on Warden Avenue and St Clair. Therefore, making use of these types of sites will not only provide an opportunity to convert the existing brownfields into sustainable sites but at the same time it can service the surrounding residential areas and eliminate the necessity of driving for many existing residents. In fact, these types of urban implant developments within 10 minutes walking distance of the TTC bus or train network will give a great base for savings on transport in addition to providing energy savings from sustainable buildings. 
Several sites, such as those in the east near Scarborough and in the west Yorkdale industrial areas are very good locations for urban implants.

These places are buildable and surrounded by residential areas and communities that can conveniently take advantage of everything urban implants have to offer. It is important that these implants are within walking distance of the public transportation network. After the initial completion of the urban implants, it is expected that extended and additional public transportation lines will spread into existing residential areas.

\subsubsection{The influence of sustainable urban implants on future developments}

European countries have based their lifestyles on mixed-used developments for centuries. This is an efficient way to reduce carbon dioxide emissions as well as setting the stage for a safe, enjoyable, fun lifestyle in a sustainable environment. The bigger goal here is to establish sustainable urban implants throughout the city of Toronto to make use of public transportation and to support surrounding areas. Based on car-independent activity, the public transportation network will develop accordingly and there will be an increase in the frequency of scheduled public transportation. The roads and streets can be narrowed, sidewalks widened and bicycles lanes introduced to provide better pedestrian accessibility.

The public transportation system can be developed further and a supporting secondary public transportation system, in addition to the existing one, can be established that does not run along the existing public transportation grid system. It would be a more flexible public transportation system that would provide public light rail rapid transport through between new sustainable neighbourhood developments and the city.

Figure 3.1 and Figure 4.1 shows possible locations where sustainable urban implants can be inserted and made to work. These developments can accommodate the current brownfield developments in the city and influence them in their planning structure. 


\section{THE DEMONSTRATION PROJECT}

\subsection{The chosen demonstration site}

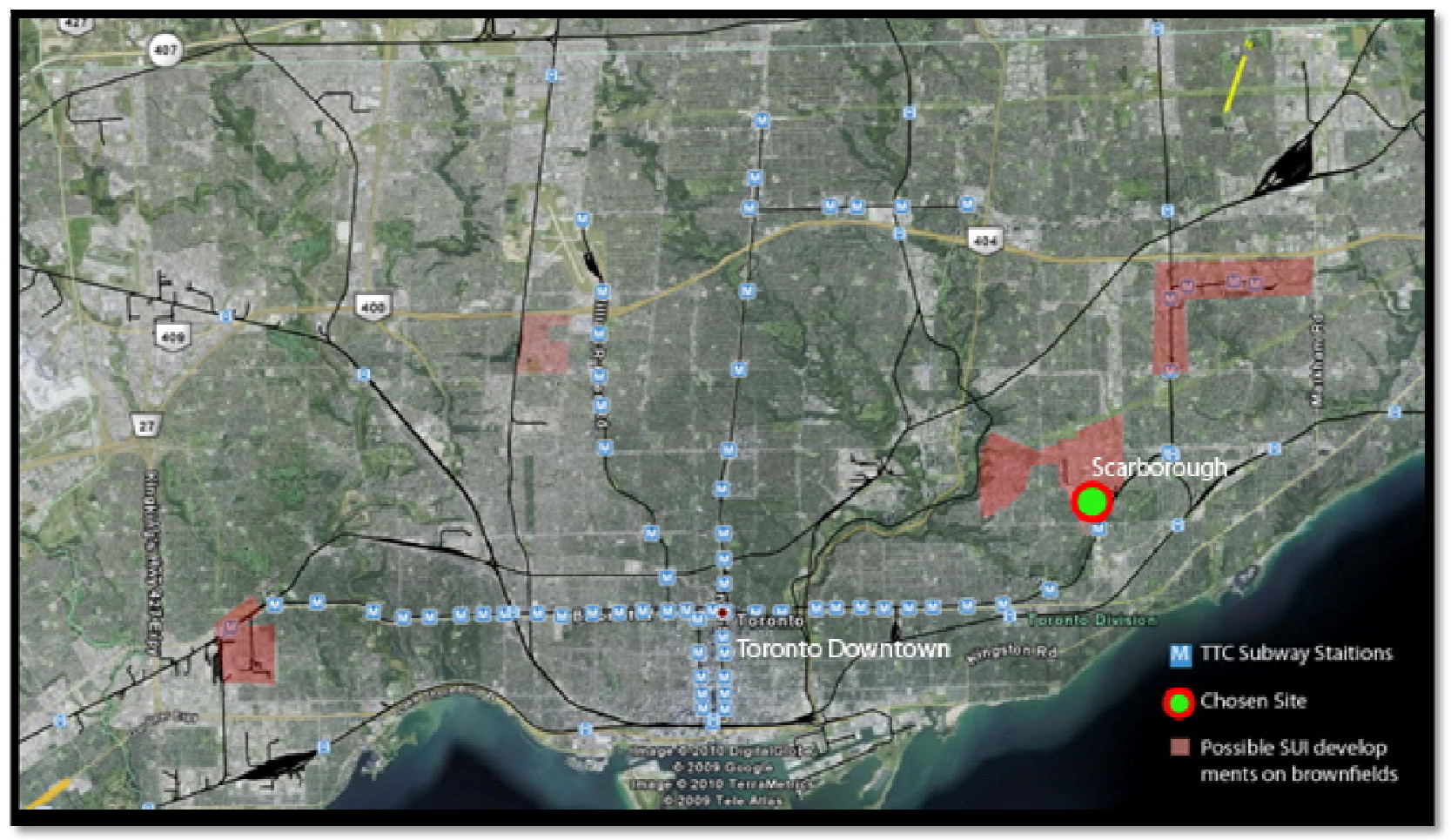

Figure 4.1: Chosen location for Sustainable Urban Implant demonstration

The site chosen for this thesis is located at Warden Avenue and St. Clair Avenue East in Scarborough (Ward 35). It is a preferred site for the development of a sustainable urban implant. It fulfills all the prerequisites for a site on which to construct a sustainable urban implant. The chosen site is surrounded with new developments founded on brownfields.

The site is within three minutes walking distance of the busy Warden TTC subway station/bus terminal. Currently, the site is a TTC parking lot that has an official capacity of 941 cars. The surrounding area is developing and more and more semi-detached and detached townhouses can be seen under construction where brownfields (underutilized or abandoned industrial fields) are being converted into residential townhouse developments. 


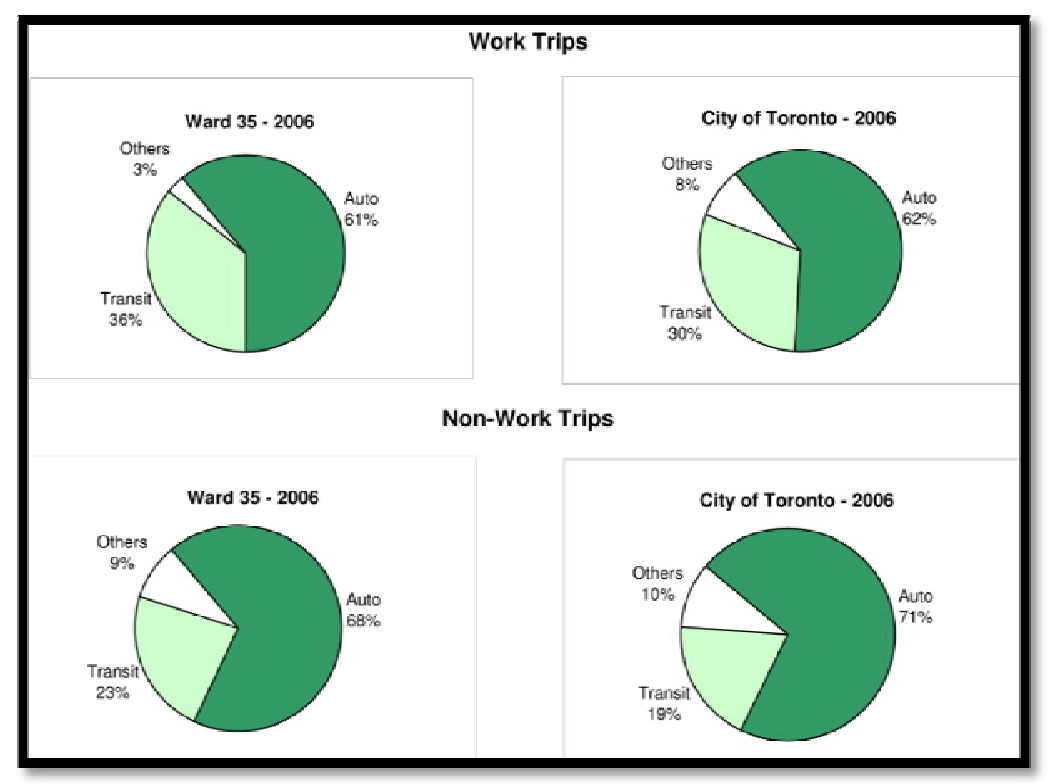

Figure 4.2: Pie charts showing still a large number of people travel with cars
One other significant

reason for this site being chosen is that the area's demographics, as provided by the City of Toronto, reflect a typical suburban settlement. The population density shows that Scarborough is a low-density single-use residential area with industrial patches. Families in Scarborough mostly use cars for their work trips and shopping trips since the residential areas are far away from shopping centres and business areas. The

closest shopping centre to the site is approximately $5 \mathrm{~km}$. away and a small return trip to it would require going a distance of $10 \mathrm{~km}$. $61 \%$ of Scarborough's population commute to work by cars and, again, $68 \%$ of the population commutes for non-work trips such as shopping, visiting families etc. (City of Toronto, 2006, Ward 35 demographics).

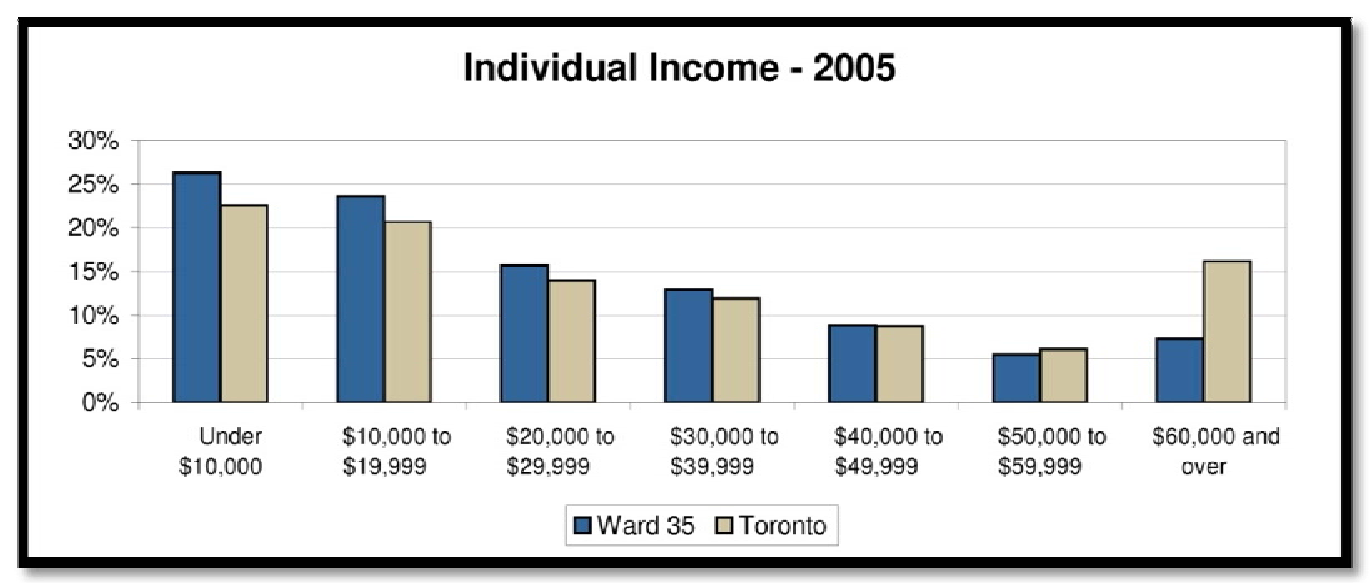

Figure 4.3 Income distribution of Scarborough vs. Toronto

Scarborough residents are mostly people who work in business services. About 25 percent of the population is well educated (with college or university degrees). (City of Toronto, 2006, Ward 35 demographics). There is also a significant portion of the population that has 
minimal education. This is again one more reason why sustainable urban implants can succeed since they can provide jobs and workplaces that can make the economy flourish without requiring long commutes.

If we look at the income level of the population we can see that a large percentage of people have really low incomes. This is another reason why the urban implant environment would be an ideal living environment since it offers workplaces and support to the residents of the community.

It should be mentioned again that urban implants are not closed communities like ecovillages. They are open to anyone who wants to enjoy the site by shopping, working or living there. They are planned to serve and complement the existing community.

\subsection{Site Analysis}

\section{Site metrics: Area: 55,388 $\mathrm{m}^{2} \quad$ Perimeter : $957 \mathrm{~m}$}

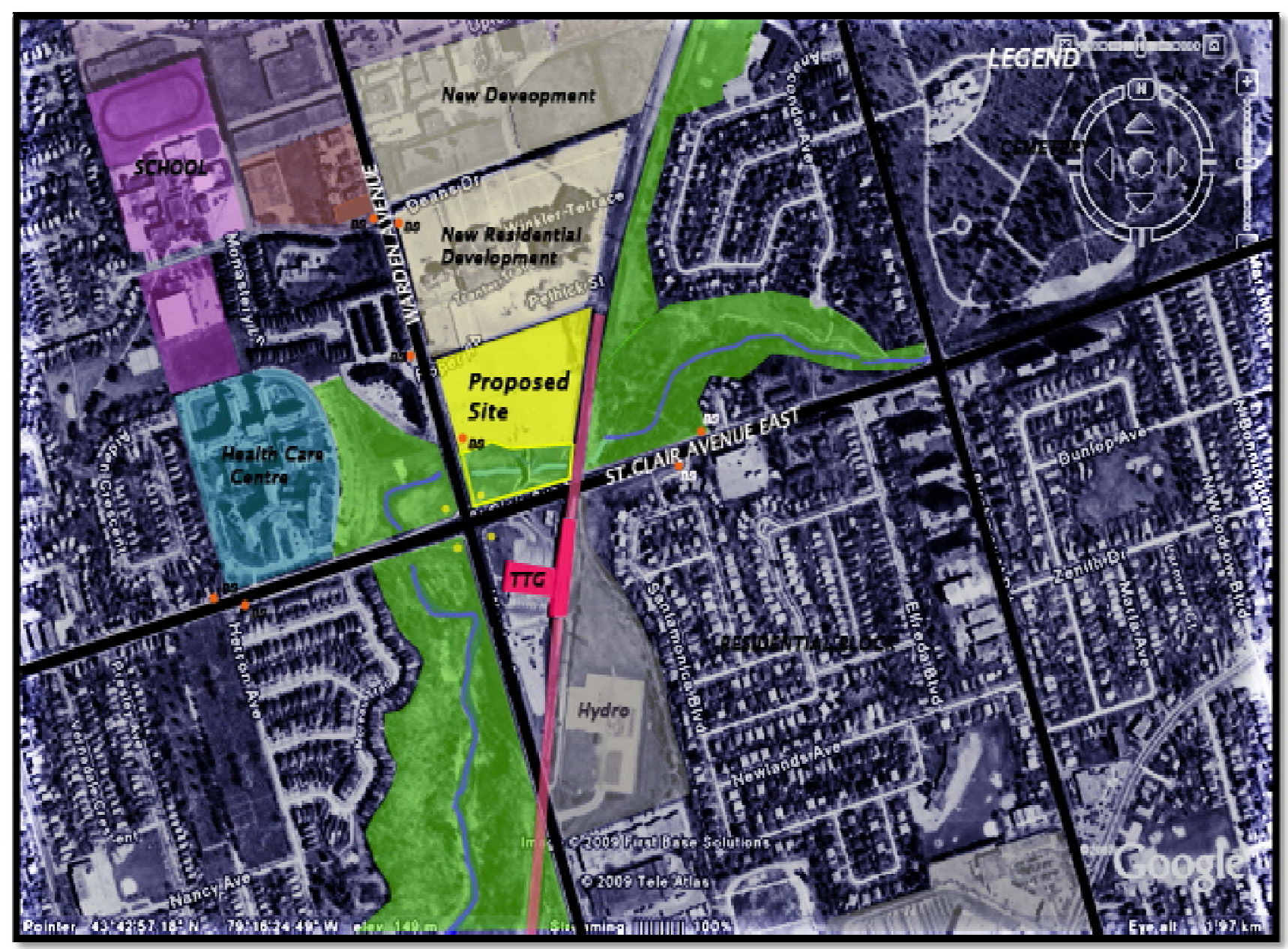

Figure 4.4 General site plan 


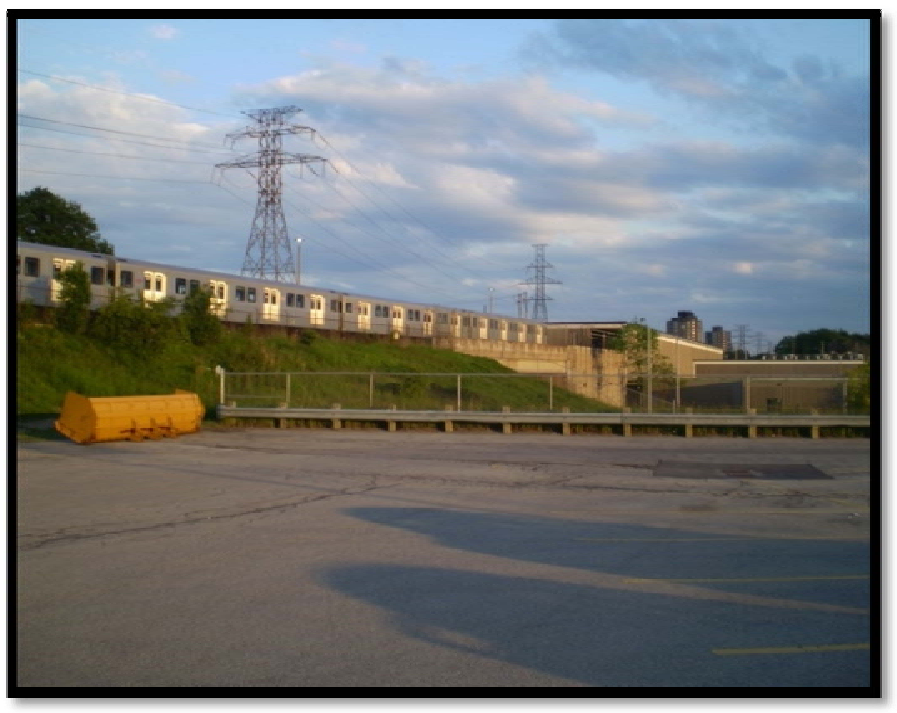

The site is located at the northeast corner of Warden Avenue and St. Clair Avenue East. It is bounded by a new medium-density townhouse development at the north that recently completed construction.

Figure 4.5 A view towards the TTC buildings

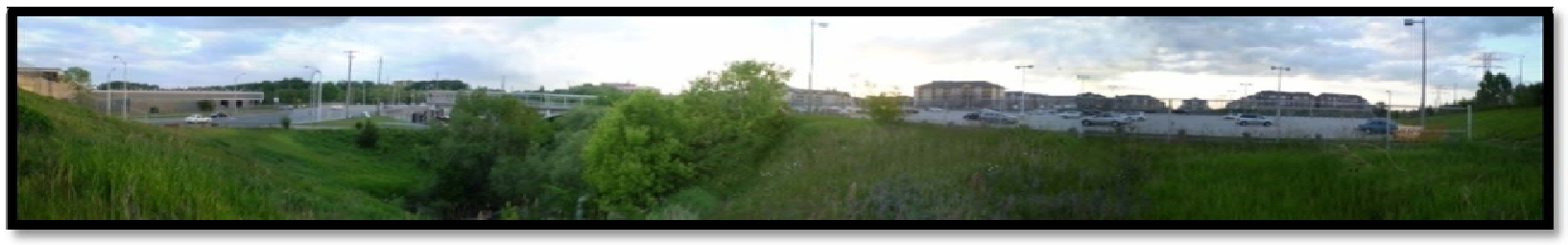

Figure 4.6: A $180^{\circ}$ view from St Clair Avenue East (on the left) towards the chosen site

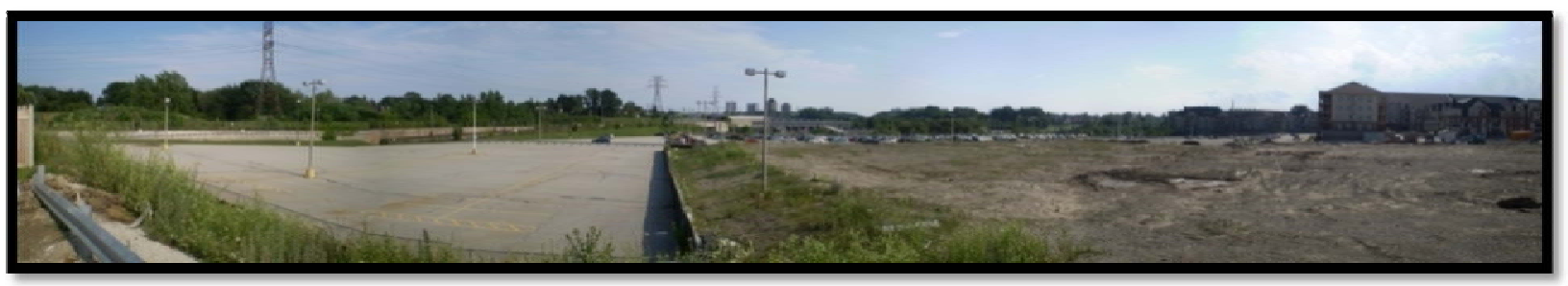

Figure 4.7: A $180^{\circ}$ view of the noth side of the chosen site

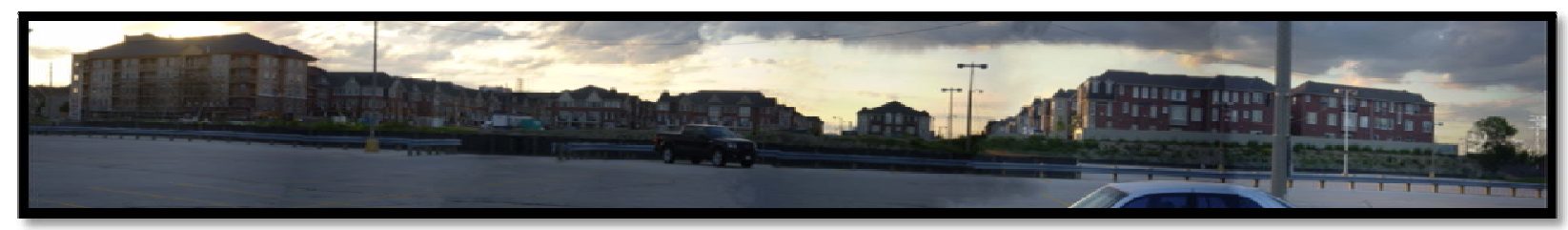

Figure 4.8: New townhouse development on the north side of the chosen site 
This existing development contains groups of houses that are single-use, semi-detached or detached houses that can be owned. There is also a condominium strip built by the same developer that is divided into two groups along Warden Avenue. Condominiums are five storeys high. Detached and semidetached townhouses are three storeys high with low-to-medium density.

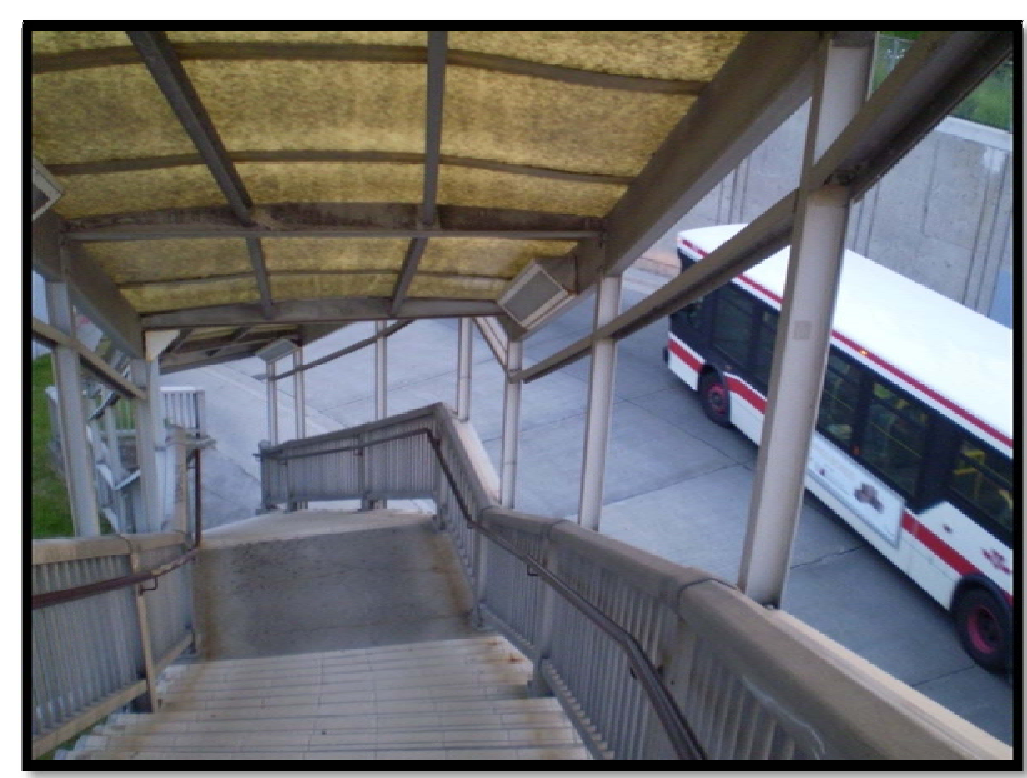

Figure 4.9: Pedestrian under passageway to TTC building

The site is separated from

St. Clair Avenue East in the south by a green valley through which runs Massey Creek. To the east, the site is separated by a green buffer from the Bloor-Danforth subway train tracks. The tracks go underground at the north-east corner of the site which gives an opportunity for the new development to connect to the existing residential areas in the east by providing a new road. This road will form a bridge over the train tracks and can be used as a bicycle route as well.

There is an underground passageway for buses coming from east of St Clair Avenue to turn left in so as not to disturb the high-density traffic of St Clair Avenue.

East and West. This passageway is accompanied by a pedestrian walkway that extends with dangerous stairs into the under-passageway along the bus road and connects to the TTC building on the other side of St. Clair Avenue East.

To the west of the site Warden Avenue is a major high-speed road that is a challenge for pedestrians. Since approaching cars are often driving beyond the speed limit and there is virtually nothing to slow them down they pose a great danger to anyone walking along the streets although pedestrian numbers are not that high. 


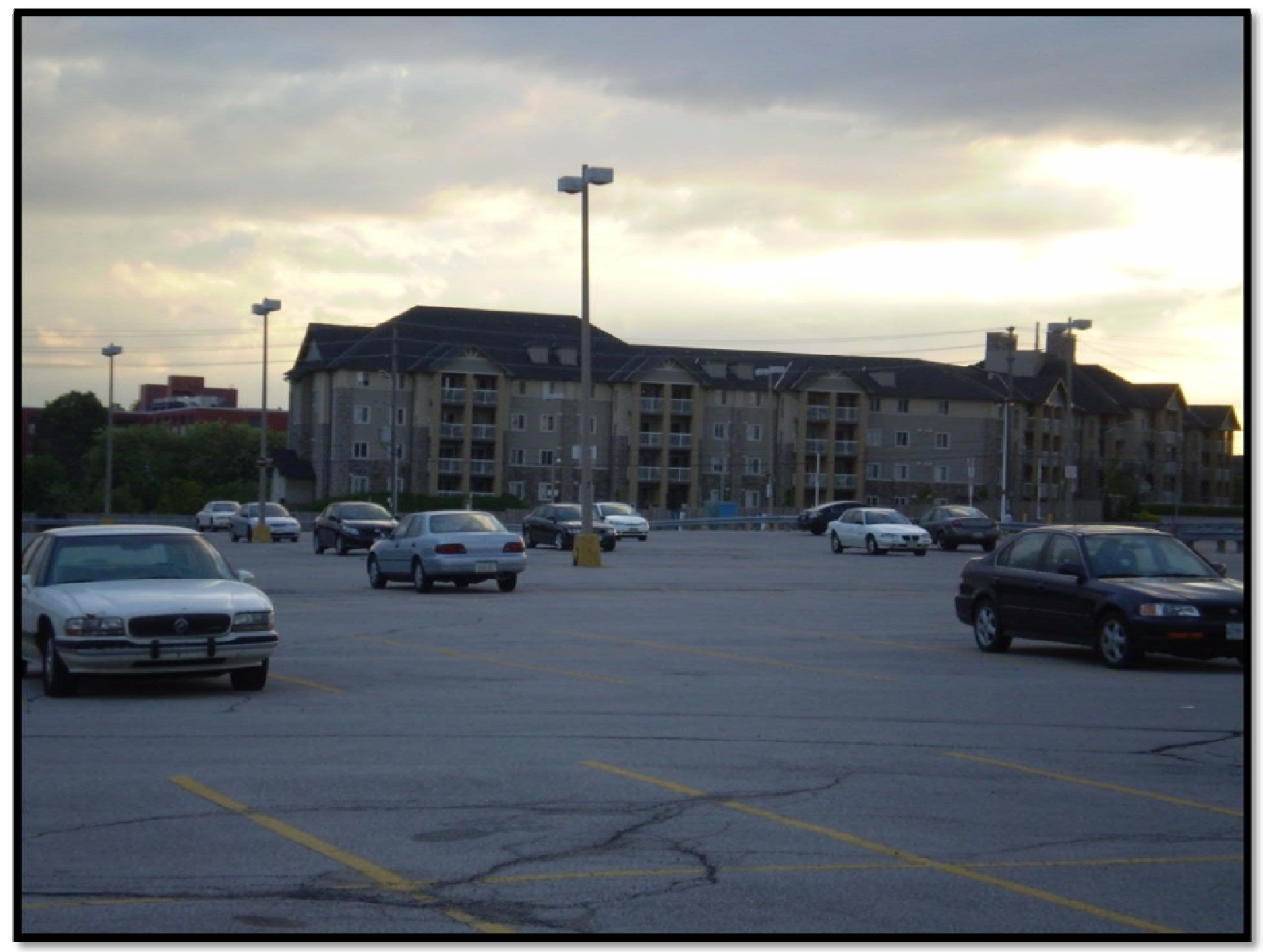

Figure 4.10: A view from the chosen site towards new housing developments along Warden Avenue

There is a great opportunity to pull the residents of the immediate surrounding into the site. The dense residential potential came with the new housing development of the area. The second major factor is that there is a technical school nearby that has approximately 3,000 students, a majority of whom who walk from Warden Station. In addition, there is a busy health care centre to the west. 


\subsection{The Design}

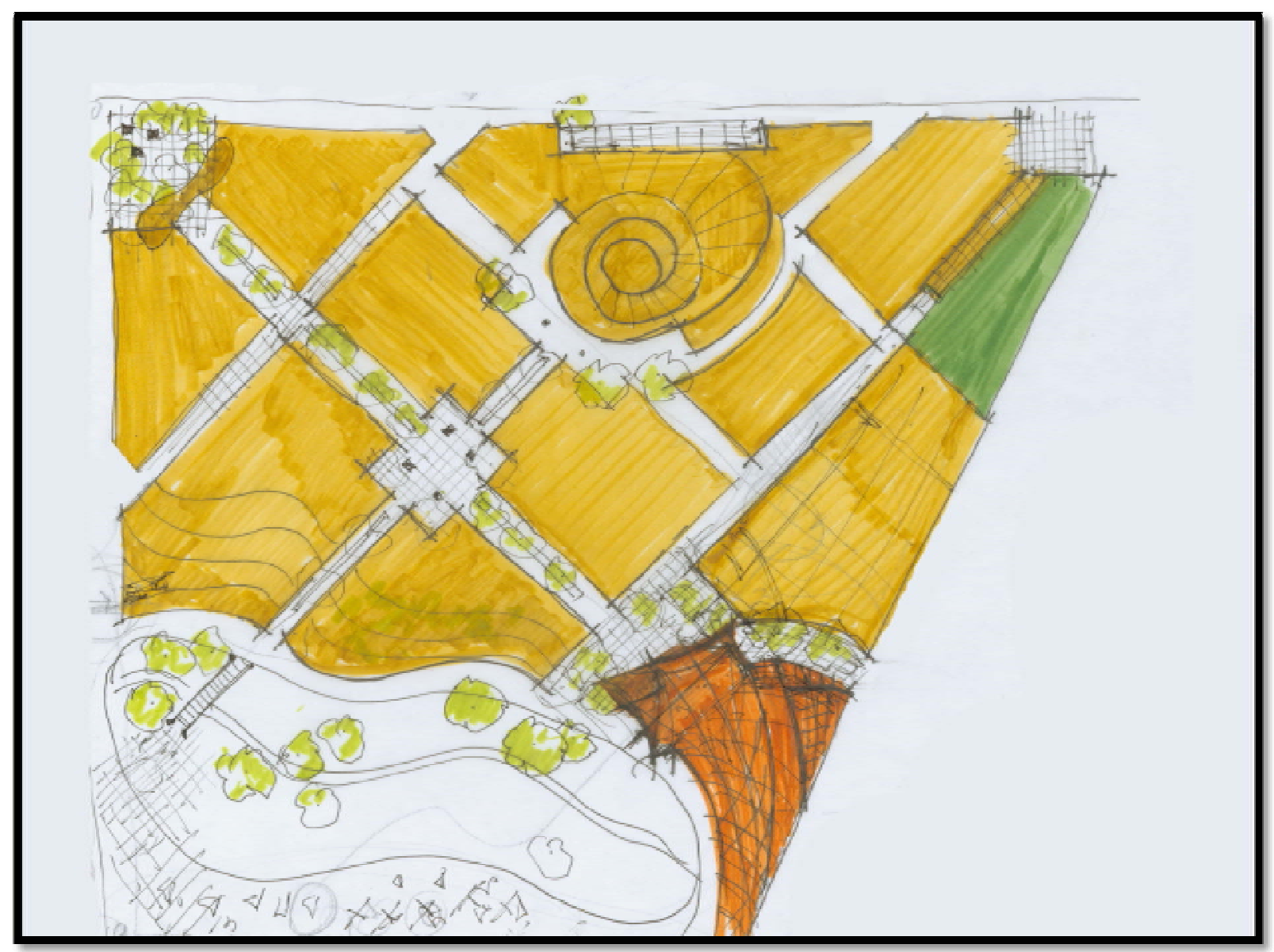

Figure 4.11: An early development sketch of the site

The site design is divided into following major parts:

1. Transportation around the site

2. Reduction of the parking lots

3. Pedestrian zones

4. Land marks

5. Public spaces

6. Providing work oportunities through food production

7. Sustainable site design

8. Sustainable Mix-used development for further economical benefits 


\subsubsection{Transportation}

The roads are redesigned to slow down traffic on St. Clair Avenue East and Warden Avenue by narrowing the wide high-speed roads and by adding bicycle lanes along Warden Avenue and St. Clair Avenue East as well as by adding parking spaces along the streets.

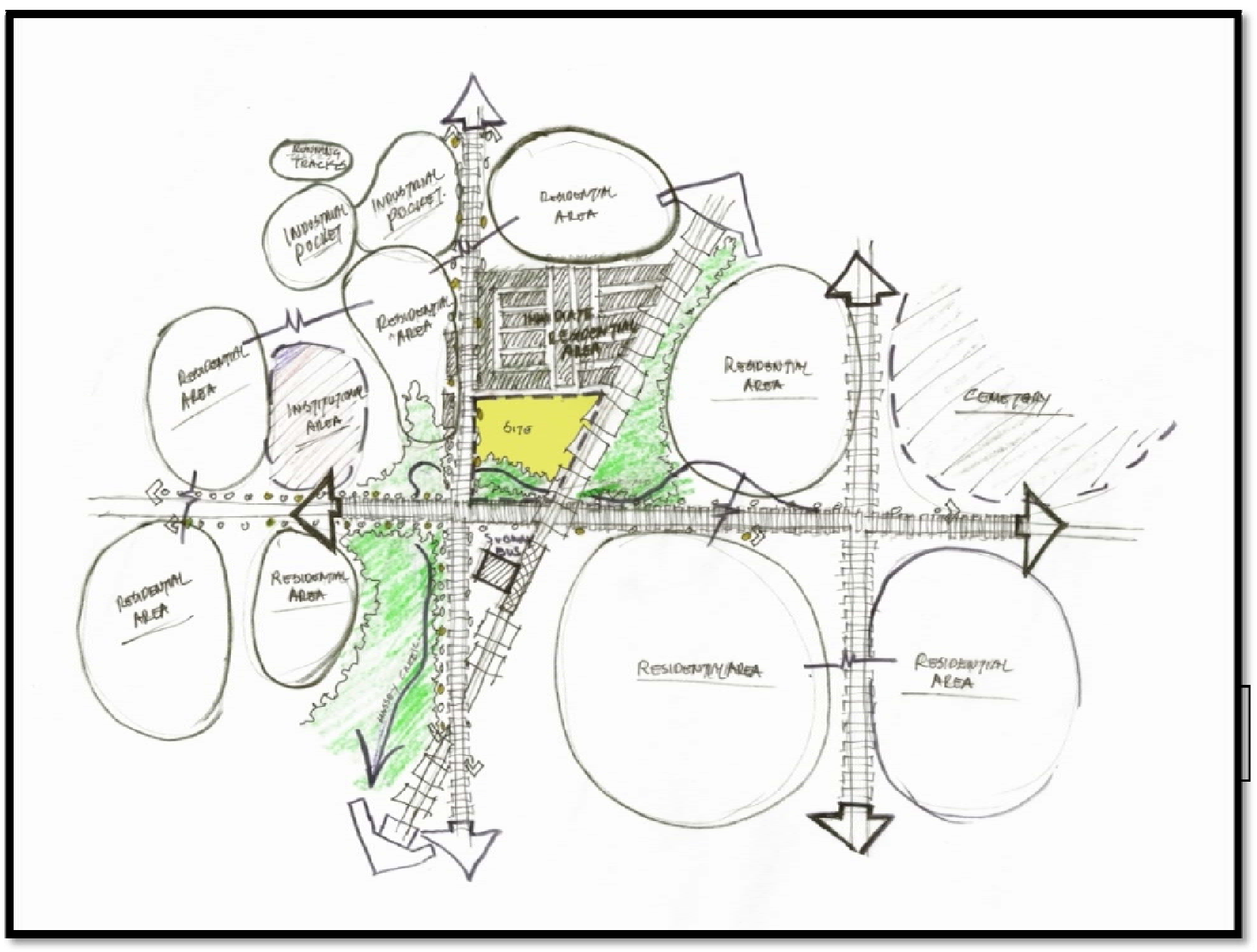

Figure 4.12: A sketch showing major transportation routes separating residential areas

- Using the existing subway train overpass bridge as a structural support for a pedestrian bridge, a direct link between the site and the TTC's Warden station main building is established. 


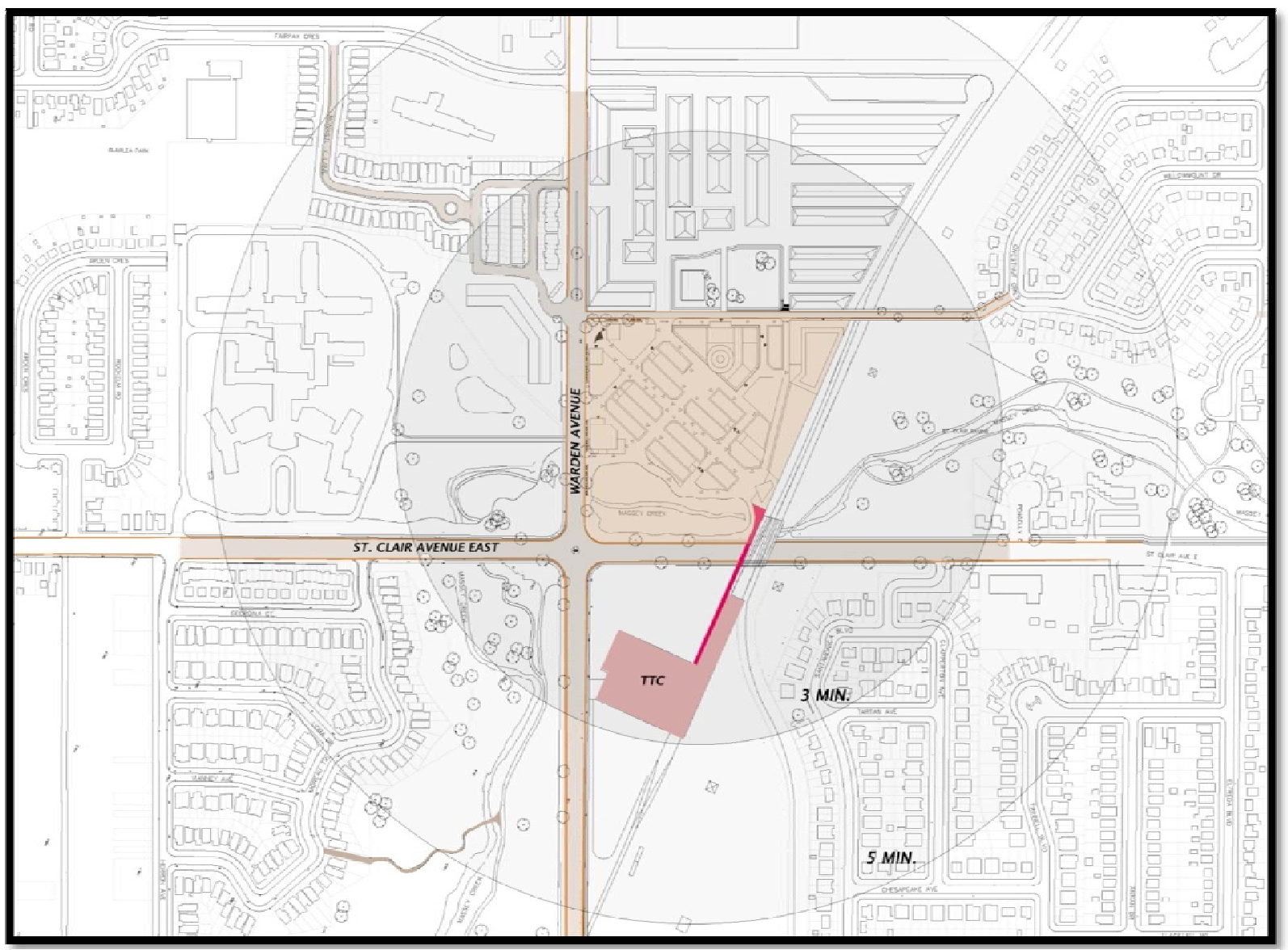

Figure 4.13: General site plan showing walking distances and redesigned roads

- A new road is created between Warden Avenue East and the East residential pocket beyond the subway train tracks that will allow:

a) reconnecting of the isolated residential pockets of the surrounding areas.

b) development of further bicycles routes and creation of direct bicycle access to the site from northeast.

c) a new bus route that will pick up residents of the existing new development and residents of the new site as well as those of the surrounding areas.

d) the enhancement of public transportation by the introduction of light rail or ecobus stops on the new route, a stabilizing factor for the economies on site and surrounding area. 


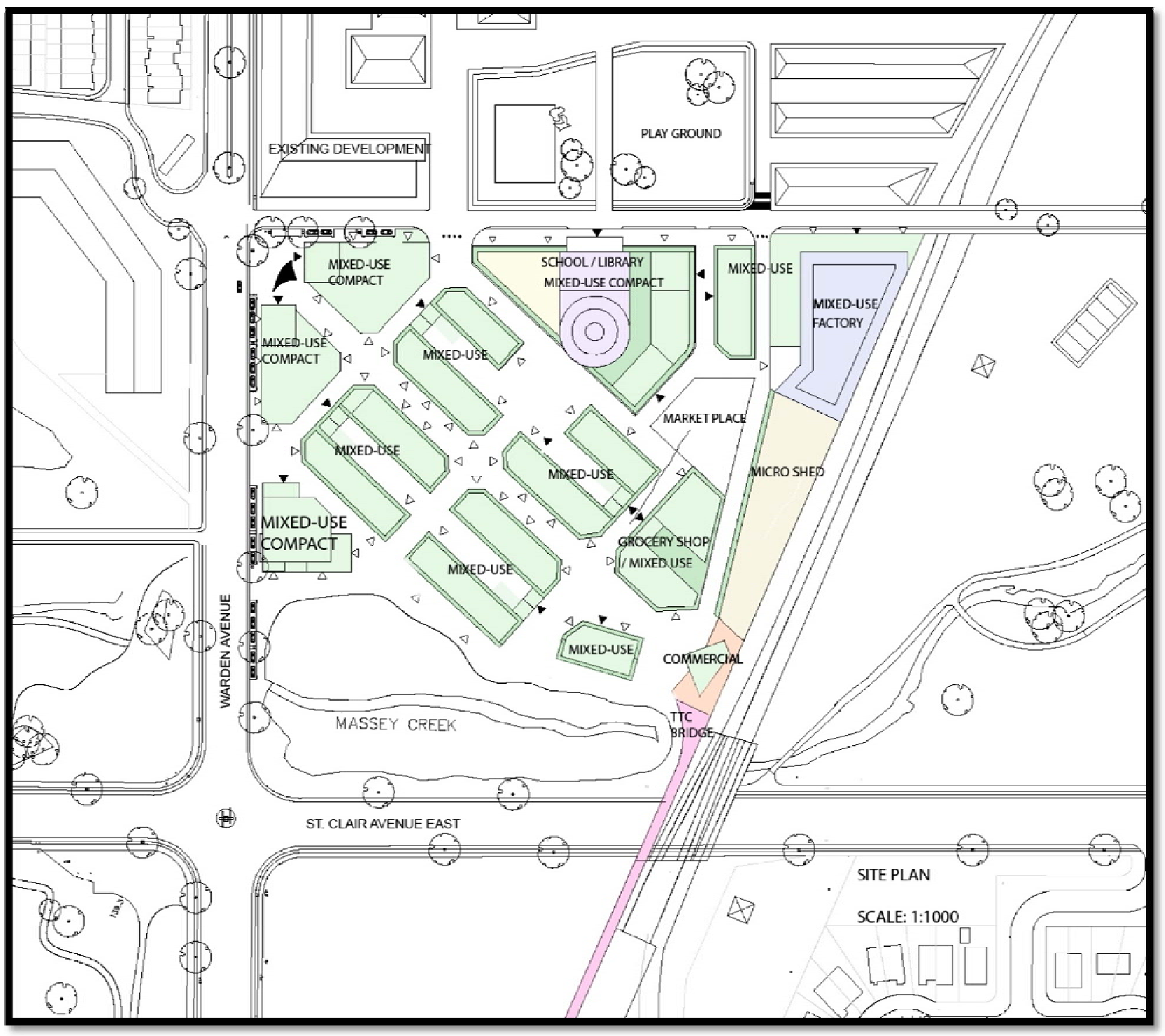

Figure 4.13: Proposed site

New road pavement will be fly-ash concrete base with recycled brick content that is suitable for vehicular traffic. (Guo Y. \& Sun K. (2009). Research on the Parameters of EnvironmentFriendly Recycled Road Materials. Website:

http://www.ccsenet.org/journal/index.php/jsd/article/view/4244), November 2009) 


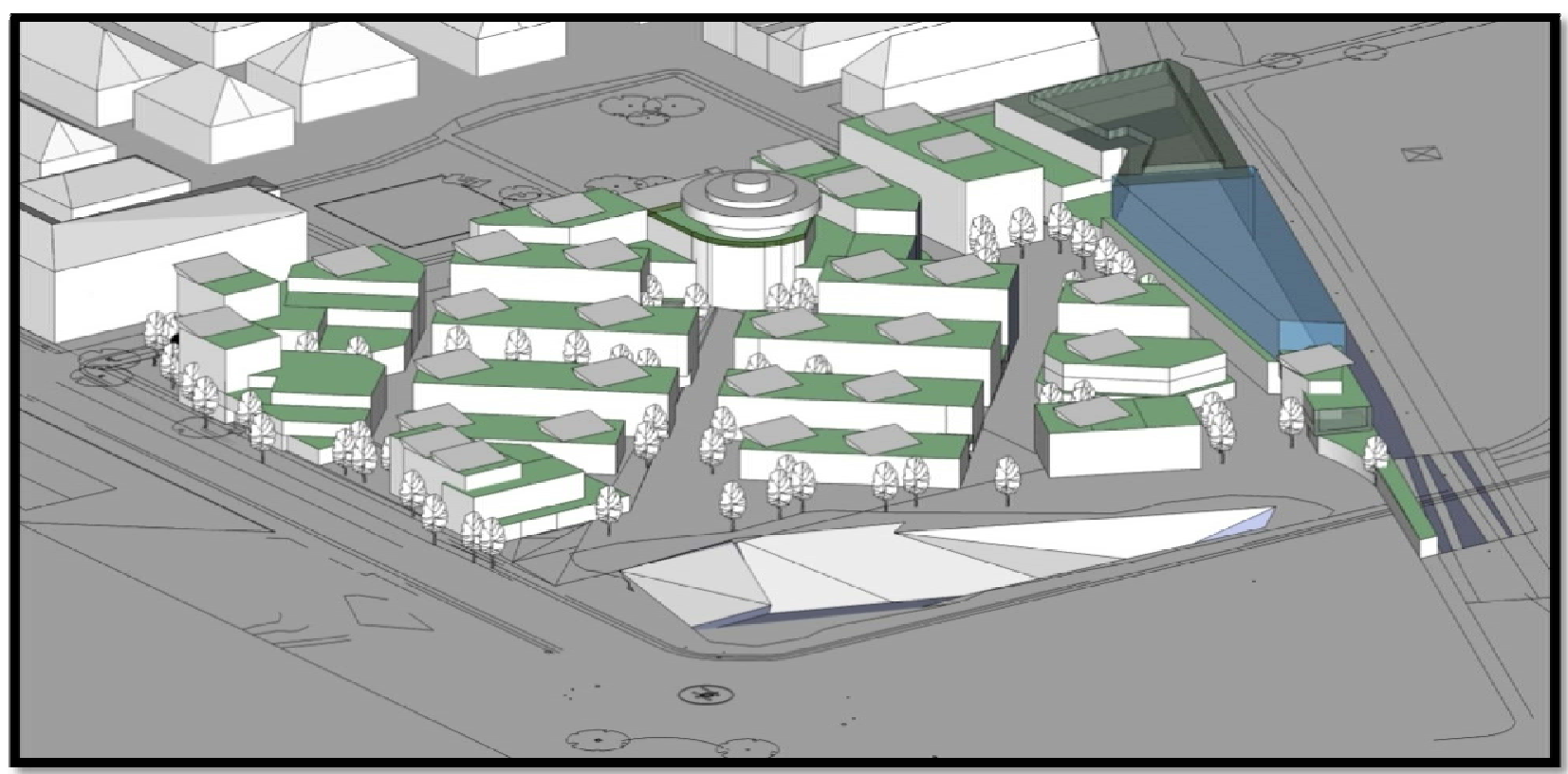

Figure 4.14 A View of the developed site from the southwest

The roads will be in sections displaying different patterns and signalling to approaching cars to slow down further since they are entering a pedestrian zone. Pedestrian walkways will also be created with reclaimed brick or reclaimed / recycled interlocking stones.

All the streets allow access of fire trucks (except the large $12 \mathrm{~m}$-long ladder fire trucks with extensible ladders). The fire truck-turning radiuses are fixed and the streets are adjusted in accordance with the turning radius requirements of the fire trucks, which is a minimum of 9 meters at the inside turning radius and a minimum of 12 meters at the outside turning radius. The paths have been laid out so that they are diagonally placed and create shortcuts to the neighbouring residential area. The main walkway creates a major shopping street that starts at the TTC bridge all the way at the north-west corner of the site, taking into consideration that students travel between the school and the TTC main building.

\subsubsection{Reduction of Parking Spaces}

The number of parking spaces is reduced to approximately $1 / 4$ of the existing parking (200 cars) and placed underground to create an undisturbed pedestrian zone at grade. The parking area will be used for people arriving from the surrounding areas and for the occupants of the sustainable urban implant. The underground parking is served with adequate stairwells and two eco-elevators with access to public space. One of the elevators comes out at the main 


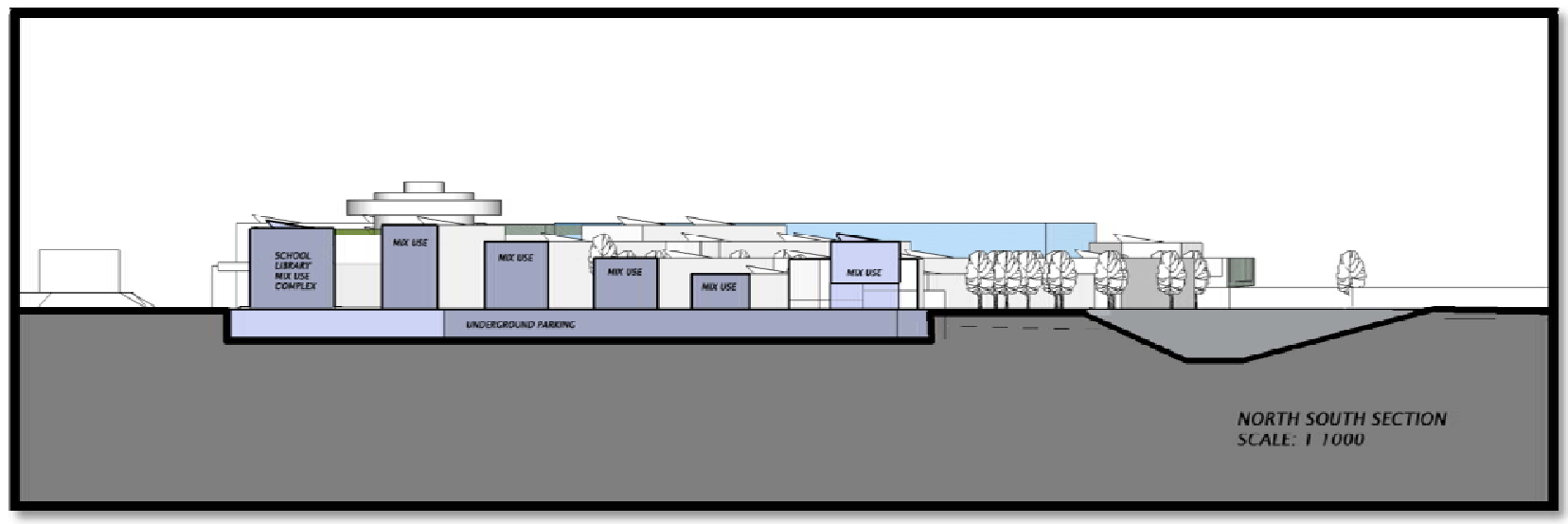

Figure 4.15 North-south section through the site showing underground parking and buildings

shopping street and the other elevator will be accessible from the common space of the library. The elevators are chosen eco- elevators that have an integrated electro-motor and do not require a pit. They are also environmentally friendly since they don't release harmful substances like hydraulic oil into the ground.

\subsubsection{Pedestrian Zone}

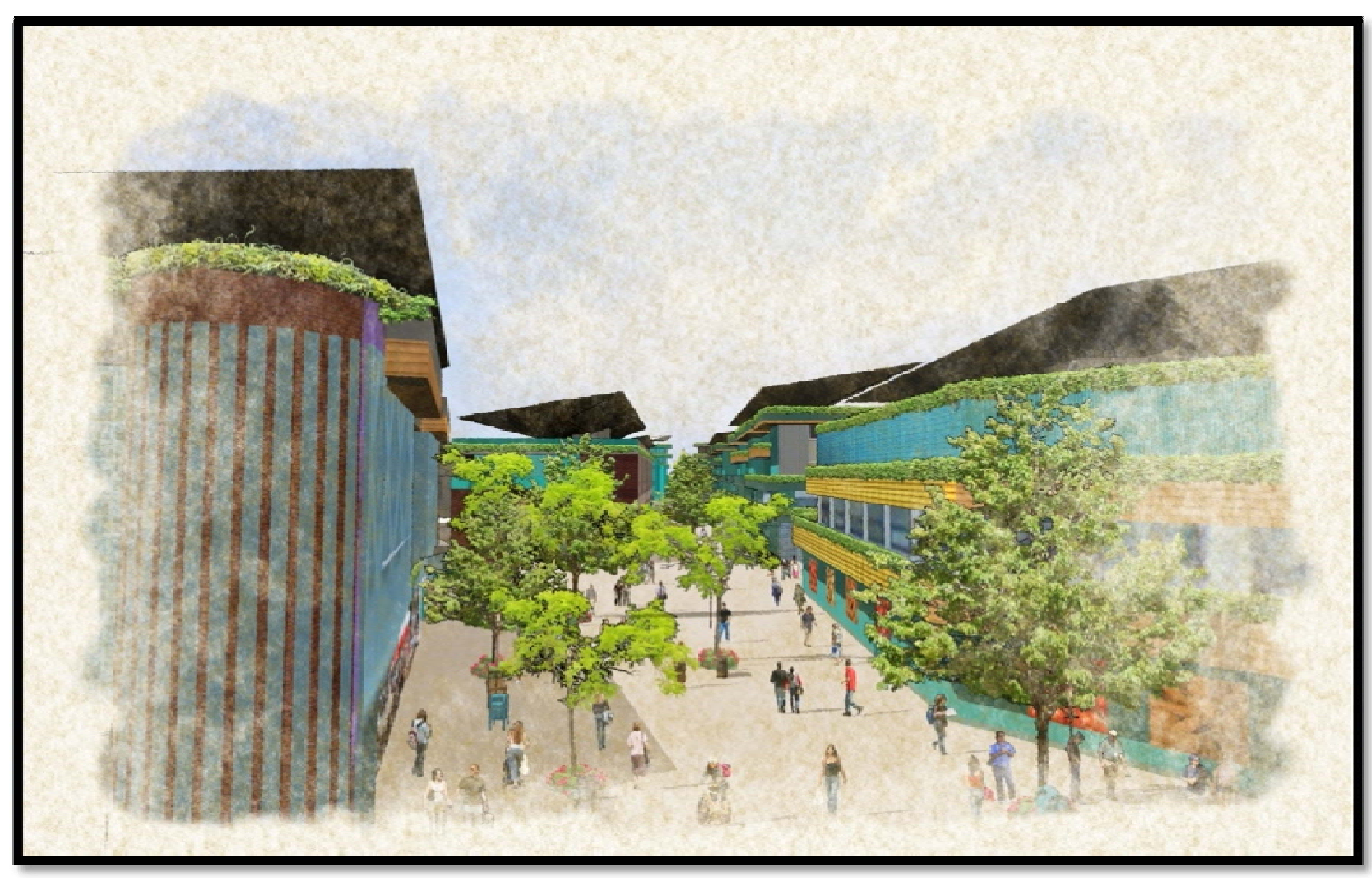

Figure 4.16 A view towards shopping street of the development and grocery shop

The site has been designed as a car-free pedestrian zone, allowing access to 
emergency vehicles. The zone allows bicycle access but there will be time limits on riding bicycles on the site in order to prevent accidents. Bicycling will not be allowed during rush hour times on the shopping street. The walking paths will be covered with light-coloured reclaimed cobble stones/bricks that will reduce the amount of heating through sun radiation and affect the micro climate on site.

\subsubsection{Landmarks}

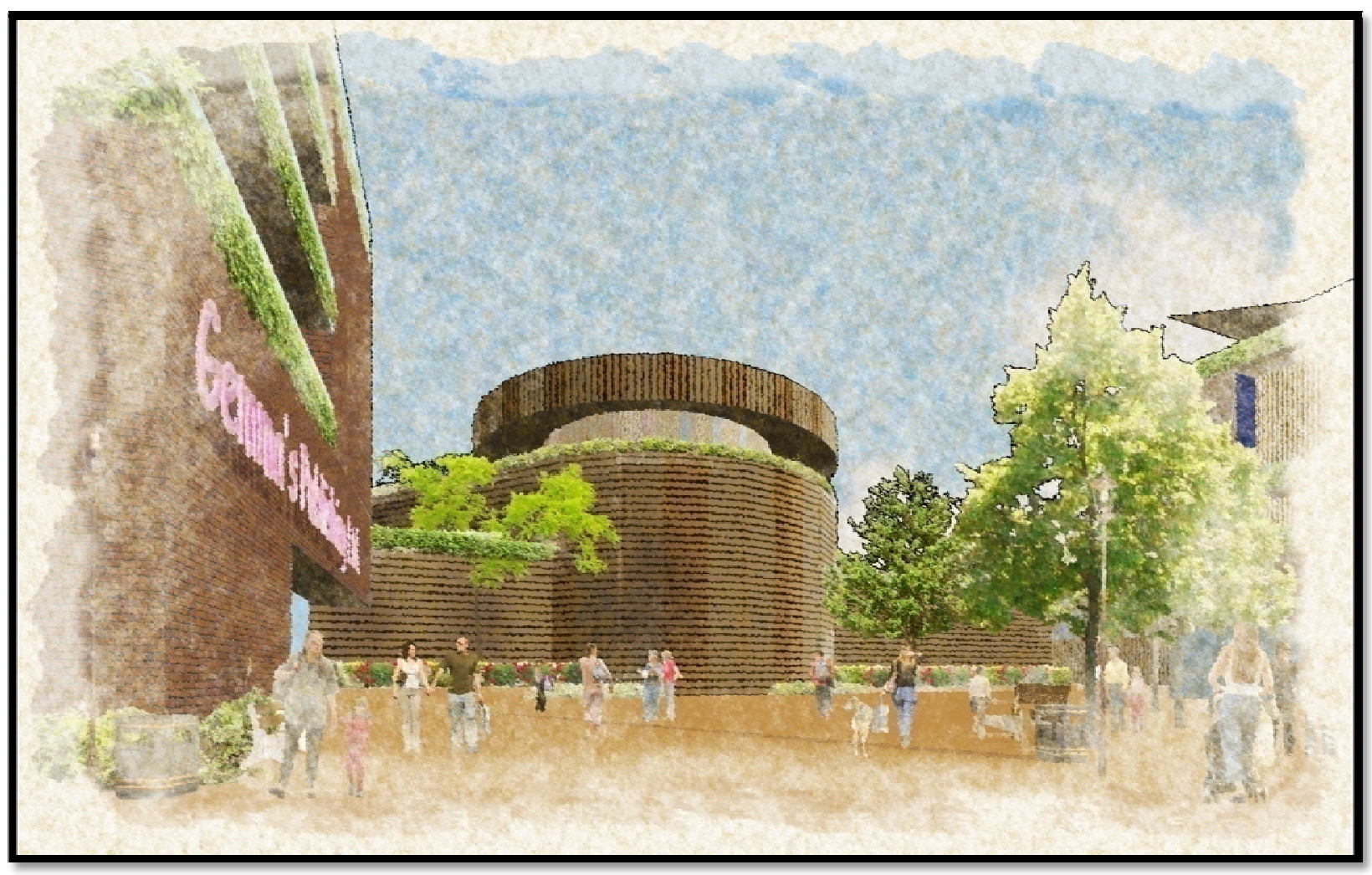

Figure 4.17: A view towards the library complex

The major building is intended as a landmark and is the library/culinary school/office/ residential complex that provides a common public space for any activities that the residents might want. Since the common space is enclosed it gives the opportunity to organize events throughout the seasons. Two towers were created at the north-west corner of the site that are not only a gateway anchoring the sides of the entrance but also landmarks that give the corner a certain orientation point for people. The library building is the tallest building of the site and it will be visible from the surroundings of the site. 


\subsubsection{Work opportunities through food production}

This site contains a micro shed, a vertical farm capable of producing fresh vegetables such as tomatoes, eggplants, zucchini, herbs, bell peppers, etc., all fresh foods that are hard to come by. The facility is attached to a food processing facility, making it possible to produce and market canned and frozen foods from produce that is still very fresh. The facility will also provide homes for facility workers, conveniently letting them live at their workplaces and build stable lifestyles.

\subsubsection{Public Space}

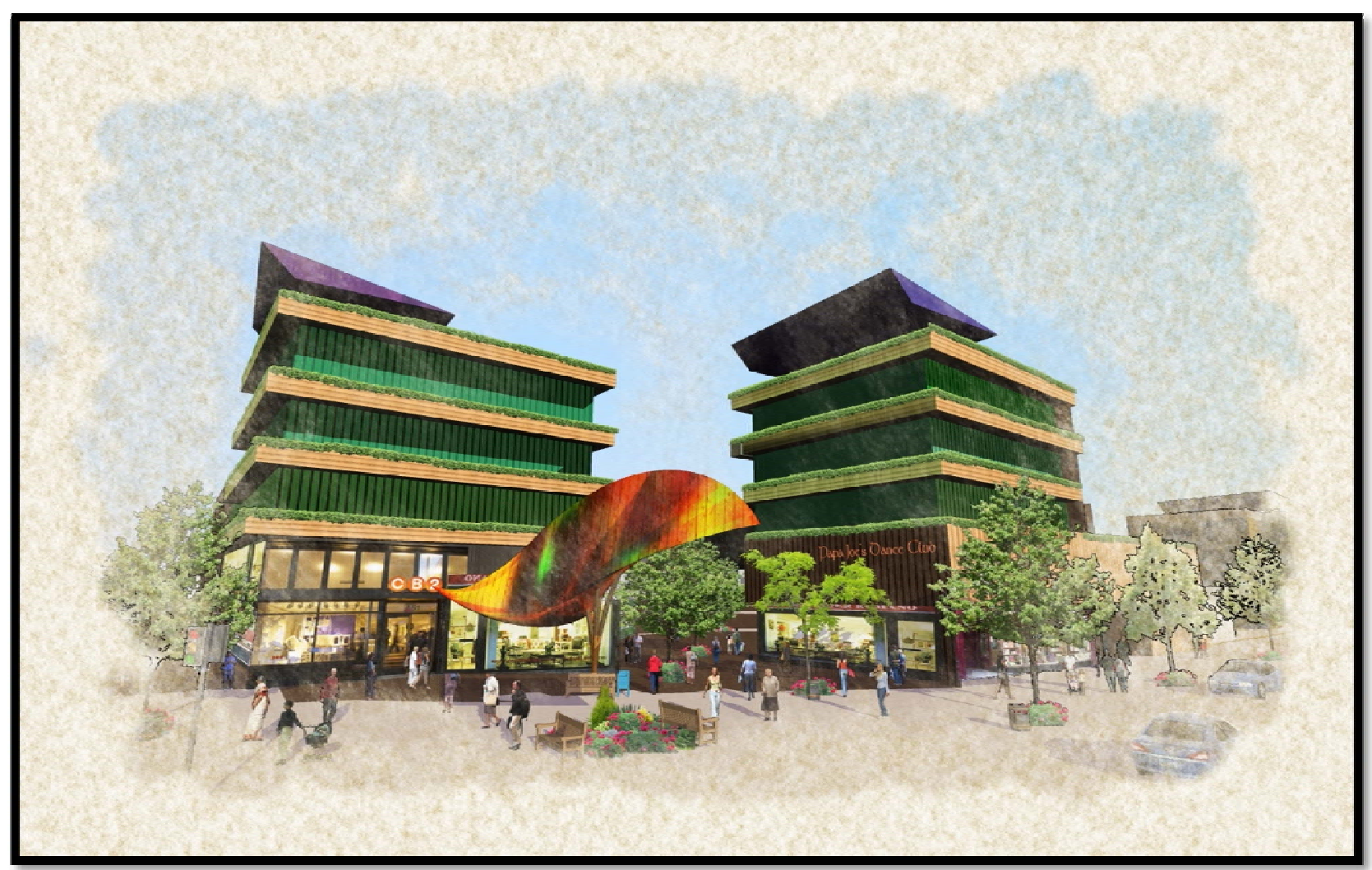

Figure 4.18: Public space at the northwest corner of the site and extending shopping street

The site has been planned to provide welcoming public spaces to encourage social interaction and also give pedestrians a relaxing and comfortable environment. Narrow paths bring people together and also create a perception of protection and cosiness. The main shopping street is a centrally located green strip; it provides bicycle racks and is enriched with 
site furniture and sculptures. Public spaces will be surrounded with amenities such as cafes, restaurants and book shops to further encourage social interaction. The site will become a vibrant, welcoming area that offers many diverse activities.

The marketplace is a multi-functional public space where social interaction and various activities take place. Its main function is to display produced goods and to showcase the economic prosperity of the area at the same time as it provides for highly visible social interaction itself. It has also a direct connection to the grocery shop that will display goods on the marketplace side.

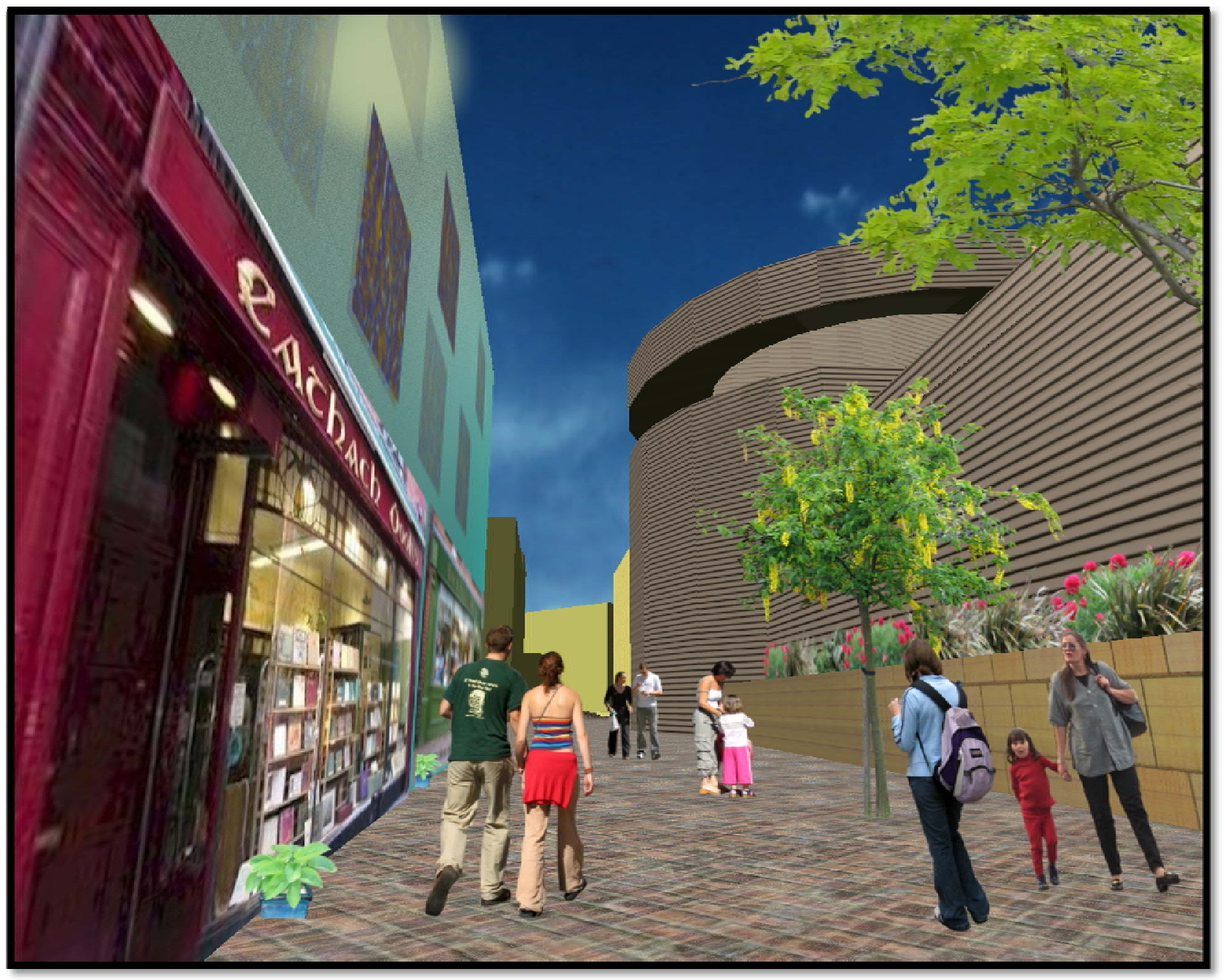

Figure 4.19: A view from the east towards the library building 


\section{CREATING A SUSTAINABLE SITE}

\subsubsection{Taking advantage of the site rain and snow water}

The site takes advantage of available rainwater: a closed-loop water system has been established through the help of Massey Creek. Massey Creek is also advantageous to the site as it fills up the underground cistern tanks when there is no rainfall. Rainwater will be collected from the flat roofs of the building and also from streets on the site by way of channels that filter the debris. It will flow to a pump station from where it can be pumped into cisterns and filtered and stripped of harmful substances; it will then be pumped into buildings for uses such as flushing toilets, for showers and for washing clothes. Clean water is scarce: only $2 \%$ of Earth's water resources are drinkable. Refining and producing water uses up much energy. If water production can be reduced significantly, energy consumption also will drop accordingly. Another way to cut down on energy consumption is to use natural rainwater for plant irrigation.

\subsubsection{Site vegetation}

Site vegetation will not include grass, which needs intensive care and watering. Instead, plants capable of surviving with little water and deciduous trees will be features of the overall vegetation cover. In addition, there are plans to plant fruit trees such as apple and pear that will supplement the food production of the micro shed. All buildings have green roofs and common garden terraces that create an on-site natural environment as they contribute to the biological equilibrium of the surroundings.

\subsubsection{Site Lighting}

The lighting of the site will be designed in accordance with sustainable natural lighting principles, which take advantage of available sunlight. The orientation of the buildings and the layout of the streets allow for a wide sweep of natural light to penetrate the site. In addition, the terracing of the buildings minimizes building shadows.

There will not be any illuminated backlit advertisement signs that would use excessive energy. Nor will there be upward lighting to illuminate buildings or objects. All building staircases 
and entrances will be put on timers. If they are not being used, they will turn off automatically to save energy. All street and site lights will be equipped with solar panels that will store solar energy. As well, all lights will be LED lights; these will minimize electric consumption and also the light bulbs will not require changing for many years to come. In addition, all office and shop fluorescent lighting will be put on dimmers. These innovations are made possible by the new technologies of the past few years.

\subsubsection{Buildings on site and sustainable architecture}

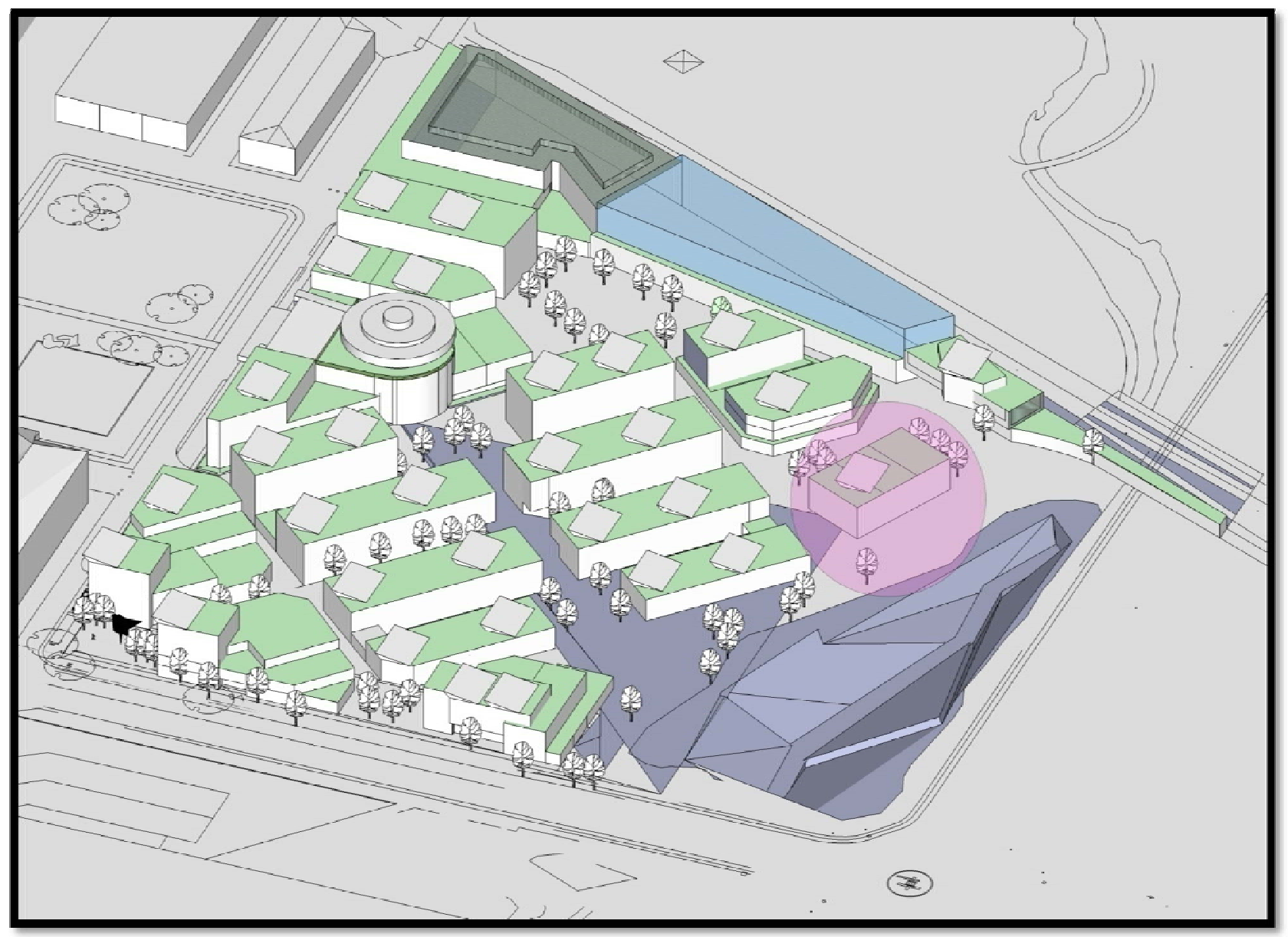

Figure 4.20: Demonstration building

Diverse use and occupancy, leading to one common goal, sustainability, are the primary goals of the development. Thus, all buildings have been planned for mixed-use with office and retail spaces beside residential occupancies. 
Mainly big compact buildings have been placed around the perimeter of the site. They will serve and be a part of the surrounding community as well as shield the interior part of the site from surrounding traffic noise. The food manufacturing plant and micro shed have been placed along the subway train tracks to provide a sound barrier and to protect other occupancies from excessive noise.

The buildings have been oriented to take advantage of solar radiation. Being oriented along a NW to SE axis, the light from the east can still penetrate them and their north façades are not completely in shadow. This way, light reception has been increased and at the same time the streets are less affected by the shadows of the buildings during morning and evening times, so that every building can benefit from solar radiation and trees are encouraged in healthy growth.

\subsubsection{Building materials}

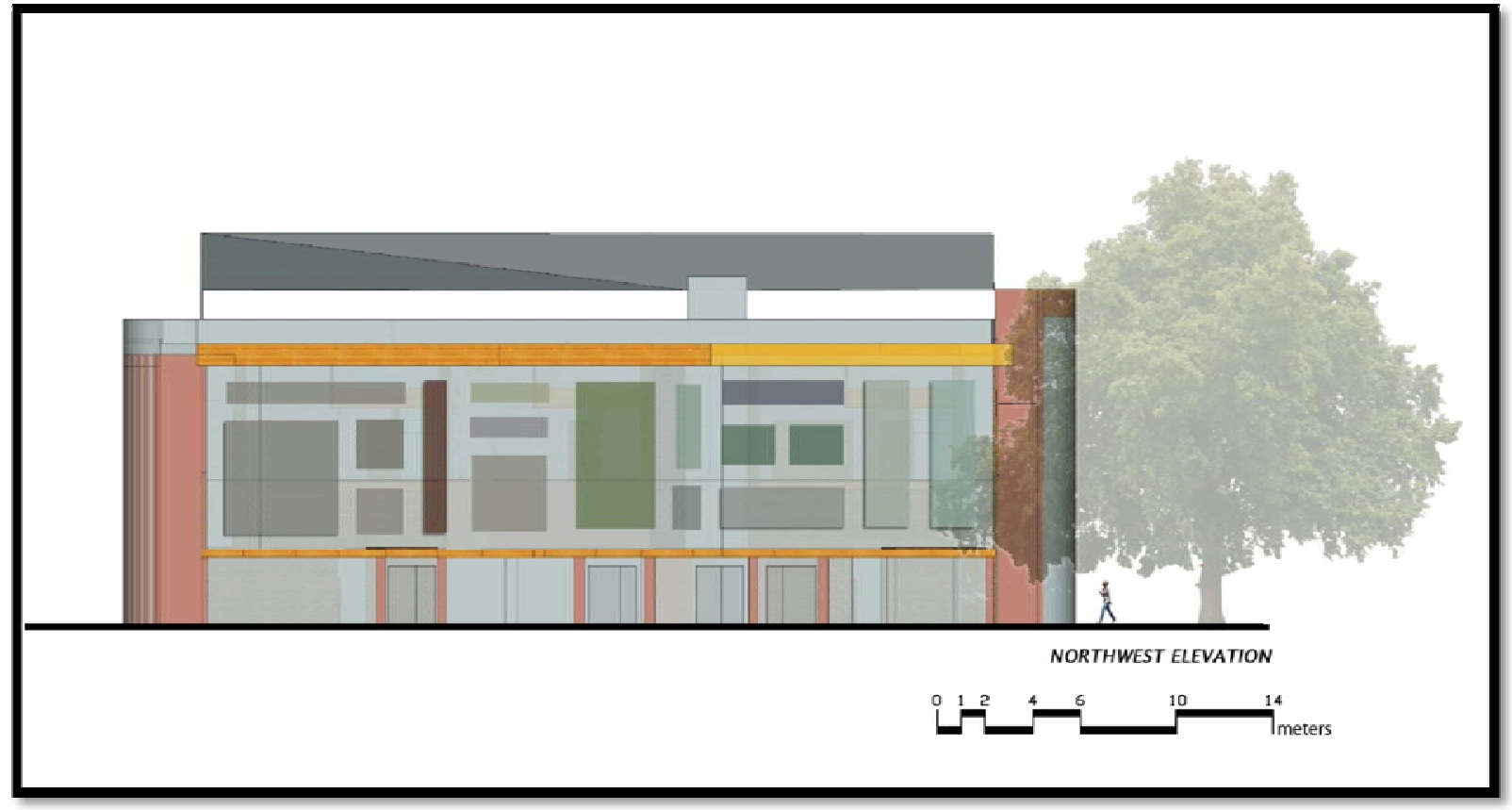

Figure 4.21: Northeast glazed facade of the demonstration building with recycled wood inserts. Provoltaic panels on top will provide renewable energy.

Building materials are chosen to make buildings energy efficient through passive active solar energy and renewable energy methods, and also through the use of locally available materials for their construction, thereby avoiding the need to transport them over long distances. Minimal embodied energy is aimed for. The buildings are designed to not only provide the most affordable housing possible through use of fully recycled materials such as reclaimed brick and 
recycled glass and recycled aluminum, etc., but also to minimize the carbon footprint in every aspect, The choice of materials for the building envelope and building structure (comprising the largest portion of the building) will affect the embodied energy and also future energy expenditure for building maintenance.

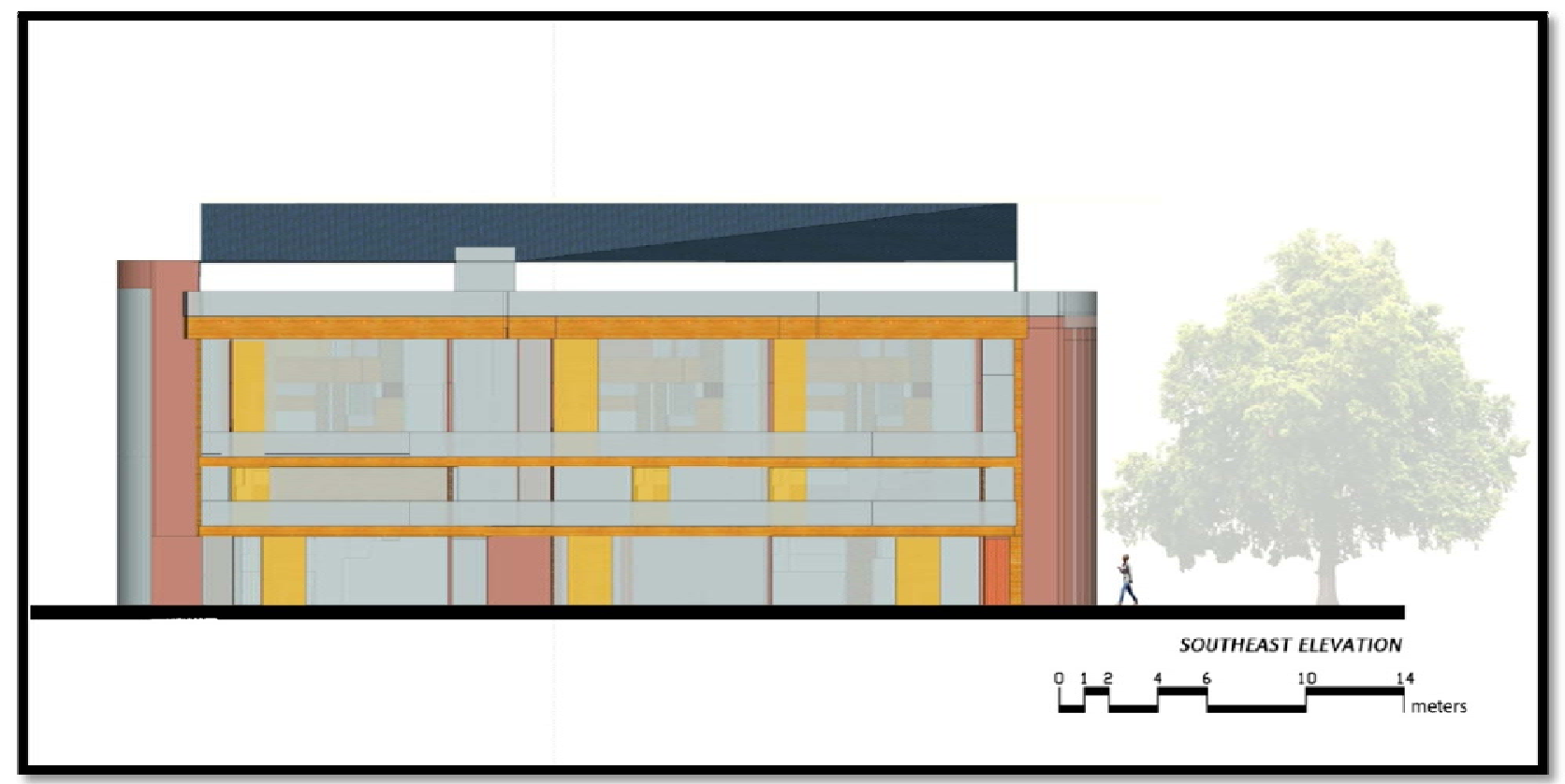

Figure 4.22: The elevation shows the moveable vertical wooden panels against the west sun.

\subsubsection{Structure of the Buildings}

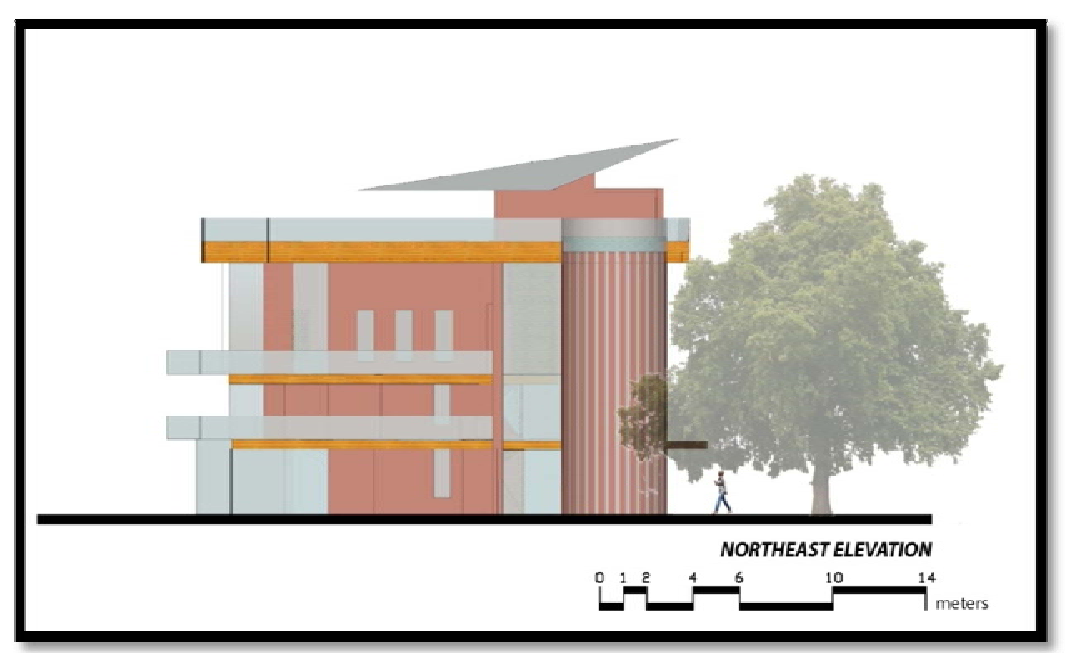

The buildings are based on fly-ash concrete foundations and foundation walls. A fly-ash concrete slab forms a base for the glue-lam wooden structure. Fly-ash is a component that can substitute for limestone since it has significant bonding properties. It is a by-product of

Figure 4.23: The southeast facade provides more glazed area, since the morning sun is cooler than the afternoon sun.

coal-burning energy plants and is collected from the chimneys of 
the plant. Its strength can vary if used as a single source, but can be mixed with limestone up to $60 \%$ in a cement mix. Since fly-ash is a by-product, the carbon footprint of the material and $\mathrm{Co}_{2}$ emissions are widely reduced in cement production.

As an above-ground building structure, a post and beam glue-lam wood structure is chosen to decrease the negative environmental impact of the buildings. This structure is kept within the building envelope and avoids the exposure of major beams or columns to weathering. It is not that wood structures cannot withstand weathering, but this keeps them in pristine condition for a long time since holding them within the building envelope ensures that they will not require any maintenance (as opposed to exposed steel structures). The buildings are sprinklered, medium-density buildings not more than 5 storeys high and therefore are perfectly suited for a glue-lam structure. As multiple-use buildings with diverse occupancy, such as residential and commercial, they are subject to different fire and safety regulations, which will be followed in accordance to the Ontario Building Code.

\subsubsection{The Building Envelope}

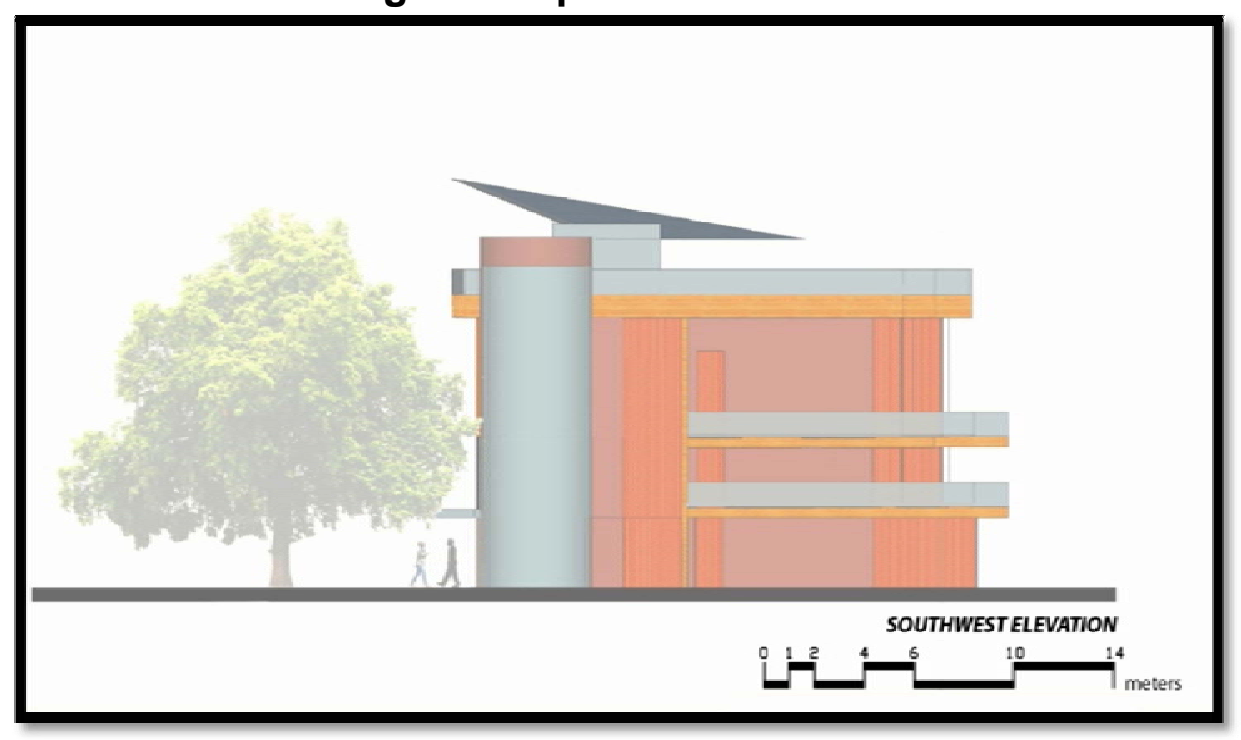

Figure 4.24: The building facade exhibits recycled brick, recycled glass and terrace gardens with sunshades and overhangs
As mentioned above, all concrete foundations, piers and walls are made of fly-ash concrete. The rest of the site uses recycled materials only, such as refurbished brick and also recycled glass and wood. Connections between the brick and the

interior infill wood framing use stainless steel brick ties. The exterior wall has been insulated using organic insulation materials rather than rigid fossil fuel or limestone-based insulators. The blue jeans insulation has an R-value (thermal resistance coefficient) comparable to that of stone-based insulations and was totally recycled from old blue jeans that were $100 \%$ cotton. It is 


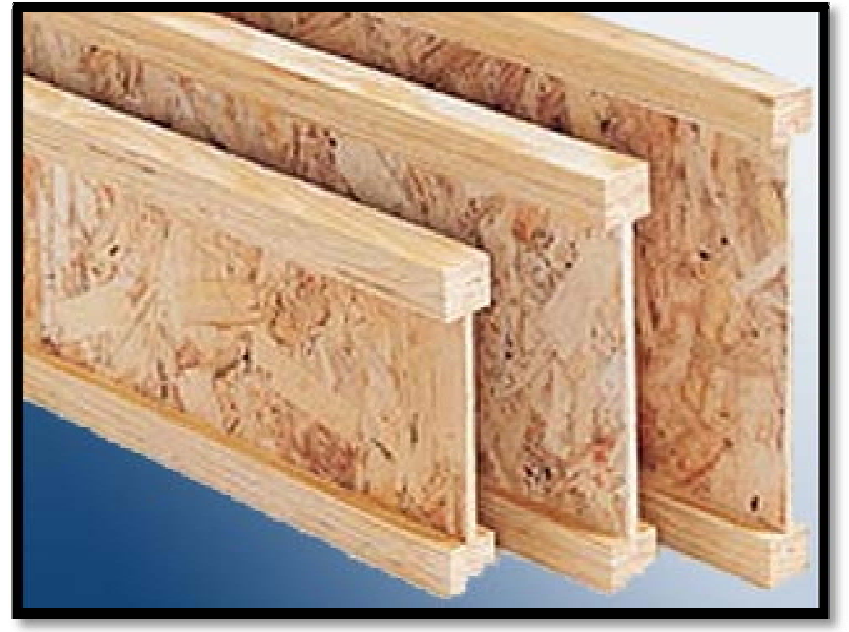

Figure 4.25: TJI joists also called Engineered Wooden I-Beams a great way to insulate the building envelope since there is no waste of materials. Unfortunately, more technical research is needed to develop sustainable materials that can perform at high levels without increasing the thickness of the building envelope with a resultant decrease in the net useable area. The building interior material is reclaimed wood cladding but it

can also be combined with non-toxic paints if desirable.

The fire resistance ratings for structural parts of the multiple- occupancy buildings on site and fire separations will be determined in accordance with the Ontario Building Code. In other provinces of Canada, buildings are to built in accordance with provincial and local regulations and codes.

Some of the materials used for waterproofing and for vapour barriers cannot be replaced. Currently, there is no substitute for oil-based waterproofing materials/membranes for building perimeters and envelopes. It is also imperative that water damage be averted by not allowing water penetration into the building.

\subsubsection{Floor Assemblies}

The basement floor slab is made of fly-ash concrete and recycled crushed concrete instead of gravel as aggregate. The ground floor assembly is made of core slabs that were mainly chosen for their light weight, durability and thermal mass for solar radiation. The ground floor is mainly reserved for Group E ( Ontario Building

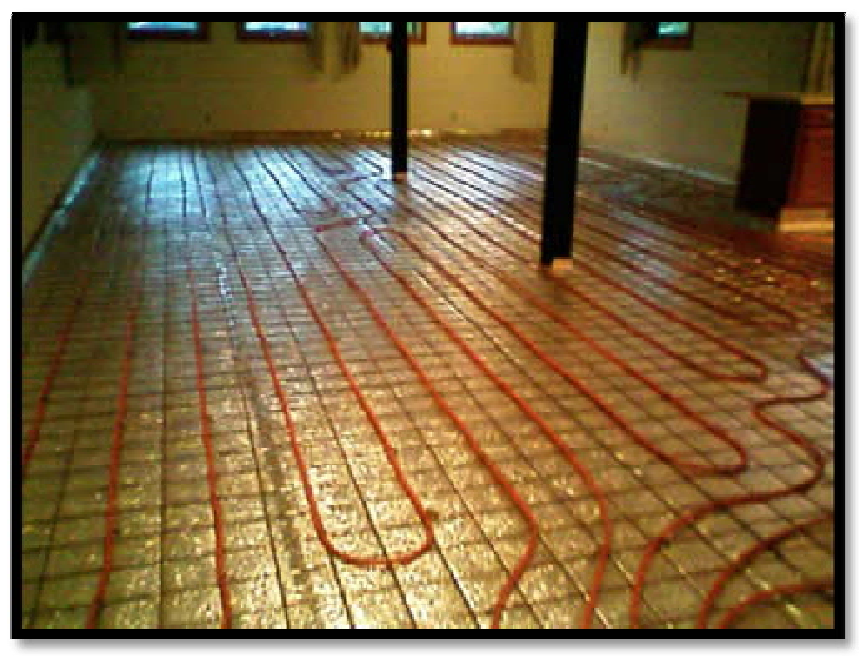

Figure 4.26: Hydronic flex tubes laid out on floor assembly and heat reflectors

Code designation) retail / commercial 
occupancies and is expected to face high pedestrian traffic. Precast concrete hollow core slabs are ideal for this type of application. Another reason for choosing this material is that precast core slabs are produced under controlled conditions and there are attempts to make their manufacturing environmentally friendly with reduced $\mathrm{CO}_{2}$ emissions.

Subsequent floors are made of TJI infill joists. These are engineered, assembled and glued wood joists with greater resistance to torque, stress and loads than common wood structural members. They are less affected by moisture and maintain their shape. Using recycled wood members of course is also a choice, but these floor members have to be in good shape since they carry a lot of loads and the quality of materials will also affect the sustainability of the house. A well-built building will provide many maintenance-free years for its occupants, and more importantly will require less maintenance so that there will be lower maintenance costs over time. In addition, the second floor of the building can be used for Group D (Ontario Building Code) services occupancies which may require higher floor loads (dead and live loads) than normal residential occupancies.

The topping on the floor structure is of refurbished/reclaimed wood planks that will be nailed on a TJI joist with spiral nails that will prevent planks from separating from the initial floor structure. The floors will accommodate a hydronic heating system to avoid circulating harsh air indoors and thereby prevent causing allergies, something that is usually problematic with forced air furnaces. In addition, since the site will be using district heating, there is a great opportunity to use water or liquid-based heating systems. The finished layers of the floor assemblies will be either recycled wood or recycled stone or ceramic tiles to take advantage of the solar radiation heating. Although these materials do not have as great a thermal mass as a concrete slab, they do help to heat interiors in winter since the sun's rays hit and heat the hard surfaces which in turn heat the air layers above. Use of carpets is avoided, though area rugs can be used. 


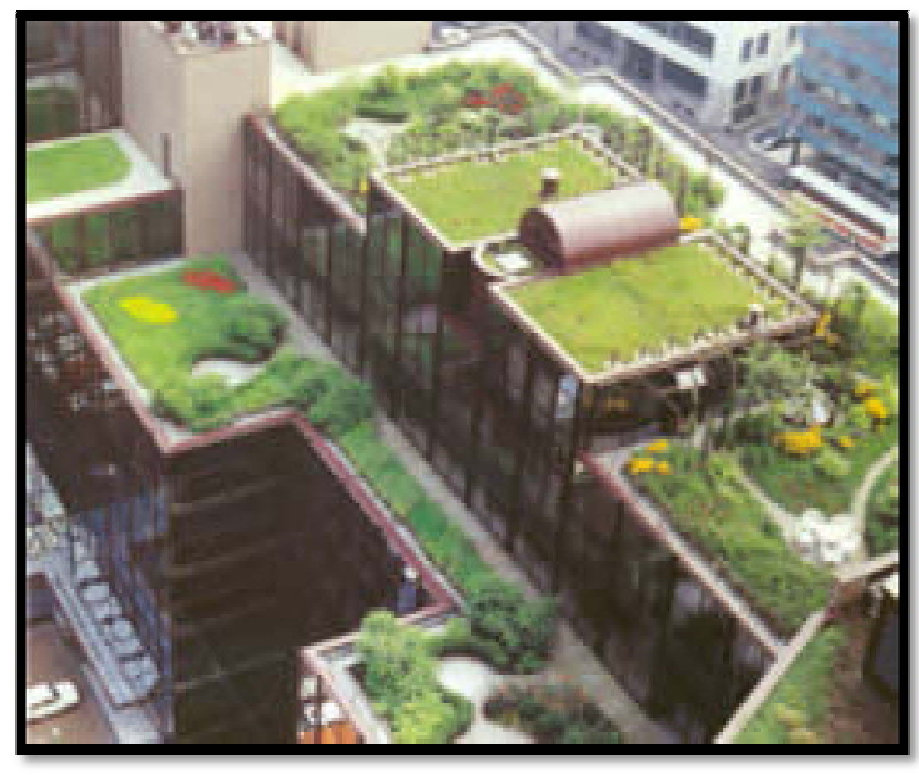

Figure 4.27: A typical terrace garden

\subsubsection{Terrace Gardens}

Terrace gardens are the socializing areas for the residents and are used as common places. The units were developed with a row-houses type concept but offer more than that. Social integrity and human comfort are priorities which will encourage occupants to stay and build a sustainable community and maintain that bond. Good human relationsand a sense of well being and privacy in a well built building within a safe environment that affords a certain amount of privacy are the building blocks of a sustainable community. The terrace gardens also provide a safe place for small children to play and for families to gather throughout the seasons.

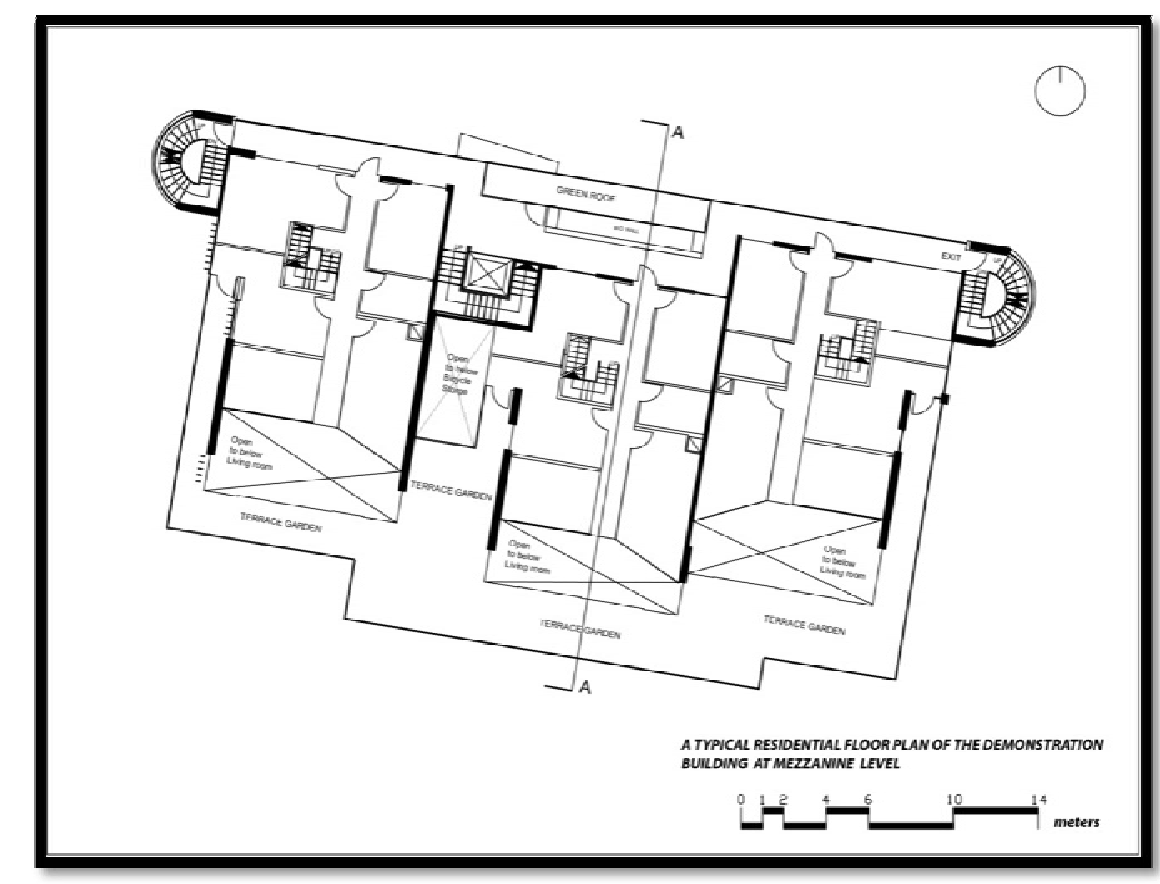

Figure 4.28: A typical floor plan with terrace gardens. 


\subsubsection{Green roofs:}

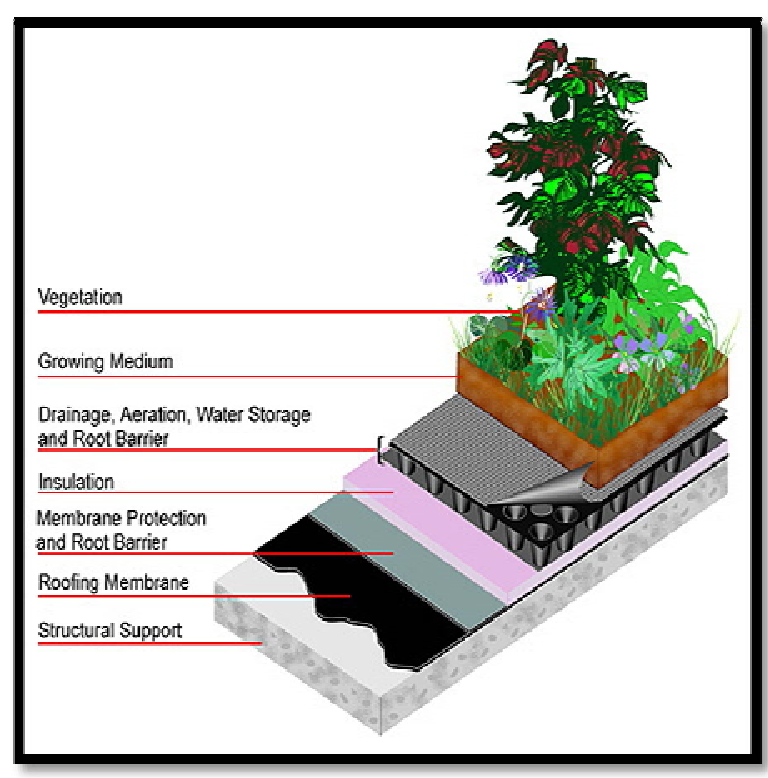

Figure 4.29: A typical green roof assembly
A green roof is accessible to all occupants of the building. It provides opportunities to socialize on the roof. Green roofs require very little maintenance; they are very energy efficient and require a minimal time investment, as no grass cutting is needed. The vegetation will be assembled with plants that require very little water and the initial green roof assembly will filter rainwater that will be forwarded to a centralized cistern for further use in buildings. The flat green roof is a useable space that is suitable for many activities. Occupants can grow their own vegetables there and also it can be used for practical purposes,

such as drying laundry in the summer or winter. It replaces the brownfields with the green surfaces that industry and building construction took away. The micro-climate affecting the green area will be restored and nature will have an opportunity to flourish. Every building on the proposed site has a green roof.

\subsubsection{Interiors}

Interior finishes of buildings are very important for air quality and healthy living. Although a lot of a building's initial embodied energy is assigned to its envelope and structure as opposed to interior materials, paint still has the highest embodied energy and is the most important factor in healthy living. It is important not to use oil-based (Volatile Organic Compound containing) paints. If the interiors are heated, these chemicals will start to emit gases that can damage the visual and auditory senses. Some known VOCs are the organic compounds acetone, benzene, ethylene glycol, formaldehyde, methylene chloride, perchloroethylene, toluene, xylene and 1,3butadiene. ( Retrieved from U.S. Environmental Protection Agency website: http://www.epa.gov/iaq/voc.html, December 2009). Paints marked VOC-free should be used. In Canada organic compounds that have a boiling point of less than or equal to 250 degrees Celsius are classified as Volatile Organic Compounds. 


\subsubsection{Biowall}

A biowall is a living vertical wall made of plants. The primary function of this wall is to act as a living filter that purifies the air of pollution and harmful substances that enter the building. A little water trench and a pump that circulates the water to the plants also filters harmful substances from the air. The presence of a living biowall alone will make a difference in

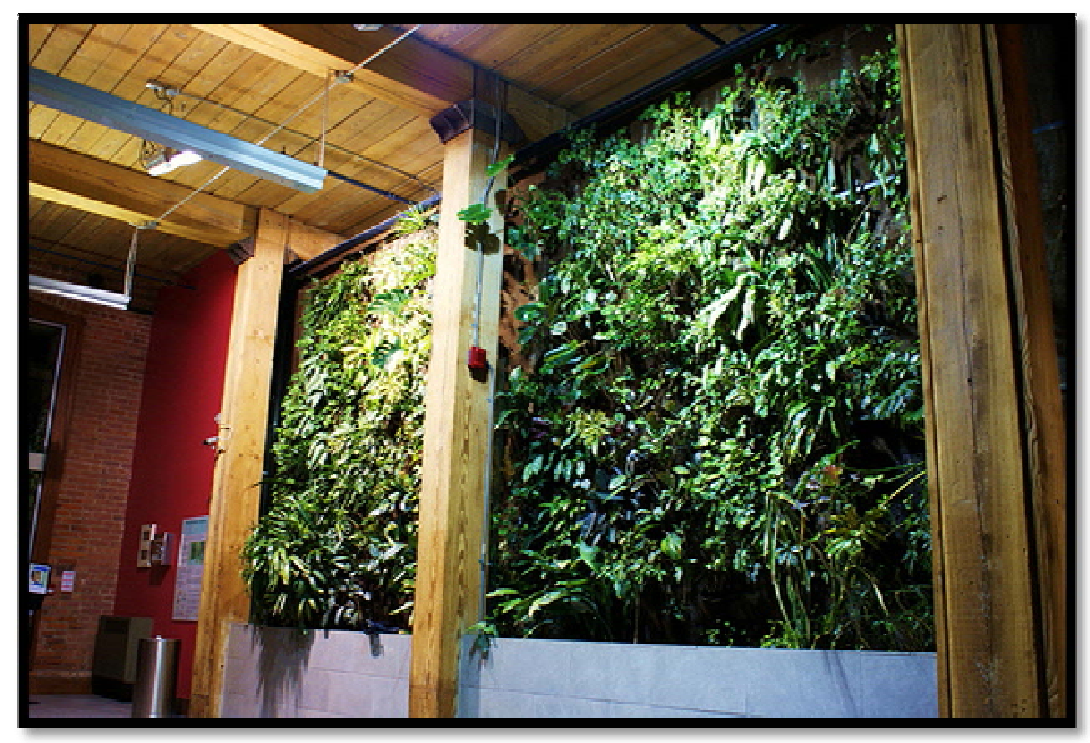

Figure 4.30: A view of a typical biowall interior air quality since plants naturally take carbon dioxide and convert it through photosynthesis to biomasses and emit oxygen. Therefore, air that has been purified and enriched with oxygen is circulated. The biowall will not require a great amount of maintenance, since the plants chosen rarely shed leaves.

\section{ELECTRICAL \& MECHANICAL}

\subsubsection{Indoor \& Outdoor Lighting}

The building is glazed at the north-east, south-east, south and partially at the south-west to allow natural indirect lighting to penetrate the building at those times of the day when the need for artificial lighting becomes very limited during daylight. (Basements, dark corners etc).

Sun-shading overhangs on the south and vertical shades on the south-west openings provide indirect lighting. In addition, the glazing of the building is a double glazing that minimizes glare and heat loss. Prevention of glare is most important in offices to ensure acceptable seeing and working conditions. LED lights will be utilized in common spaces to prevent excessive energy consumption and light bulb changes. They are efficient also in that they are not affected 
by grid voltage fluctuations that shorten the life of light bulbs and require regulators to flatten them.

\subsubsection{Heating}

On-site heating of the buildings is accomplished by district heating. It utilizes energy sharing and another of its advantages is that the amount of heat generated from one point can be controlled. Furnaces are getting more and more energy efficient. There have also been great improvements made in solar hot water heaters, a great source of free hot water for building residents that, if necessary, can be networked. The solar hot water network will be used to save energy for water heating.

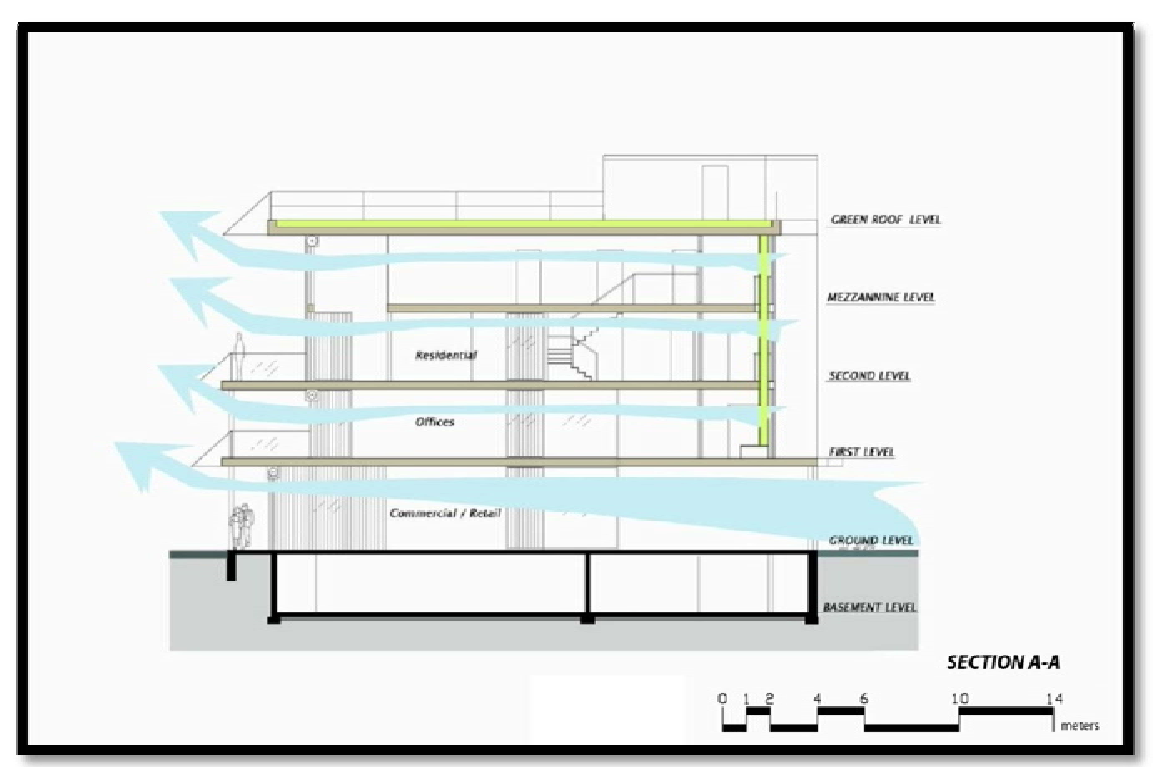

Figure 4.31: A section showing natural ventilation

\subsubsection{Ventilation}

Natural ventilation is provided throughout the building with clear storeys above walls for all occupancies. Ventilation of the building's common area and corridor will be regulated by glass louvers on the northeast façade and by louvers above the staircase that leads up to the green roof. That way, a

natural chimney effect is created that sucks up used air and brings in fresh air in from outside. The heat from the oven in the kitchen area and moisture discharged from cooking and from showers and laundry rooms will be handled by mechanical exhaust ducts to prevent this moisture from having effects on interior materials such as mould build-up. A smoke control system will also be provided in accordance with the Ontario Building Code (OBC) 


\subsection{Economics of the development:}

Shop and business owners have the opportunity to own a residential unit in the same building as their concerns or at least on site, which would decrease costs for them by creating a work / live condition. Staff members could stay to live in / rent the building where they worked. Of course all this provides opportunities for substantial savings. A great deal of time and money would also be saved by being close to shopping areas, by not having to drive between workplace and home, as well as by reducing the cost of car maintenance and gasoline. It is clear that all this adds up to substantial savings, and that is without even taking into consideration savings generated by the sustainable housing itself.

An average car consumes approximately $\$ 1,400$ of gasoline alone for every 20,000 km (considered as annual fuel consumption). (Ref: National Resources Canada, 2009. Fuel Consumption guide 2009.) This amount of money gives SUls an edge to boost financial stability of individuals and community.

Sustainable urban Implants are worthwhile investments that are not only environmentally friendly but also that by their very structure can generate work opportunities and nourish the economy. In this case, a food processing plant and employment opportunities brought to the site through the services and retail shops will be the money-generating facilities. As mentioned earlier, sustainable communities depend for their existence on continued government support. This is especially true at difficult times like the present as small businesses must compete with giant firms. The location of the site on the subway line and bus route as well as its proximity to a high-density residential area and schools will be beneficial to its economy.

A library, a school, a grocery store and an integrated market and an organic food processing facility as an extension to site micro shed will maintain a flow of people into the area. Businesses in the service sector, such as banks and some offices, will help to create an active business area.

There are also savings in construction of sustainable urban implants. The demonstration project is a planned sustainable urban implant created especially for this site. The programming of the urban implants will change in accordance with each site but main elements such as sustainable buildings within sustainable sites with pedestrian zones will remain important 
elements of urban implants, since their goal has always been to coordinate urban planning, design and architecture under the umbrella of sustainability.

To achieve consistent quality and control, the site is to be constructed by one general contractor which will save construction mobilization costs and also make coordination of the site much easier. The construction of the site and buildings can be divided into phases if need be. The construction schedule can be arranged so that there are no gaps in work time so that the job can be accelerated. Logistics of the construction can be better coordinated to avoid delays in the construction schedule which will also reduce construction costs. Bulk ordering of construction materials, fixtures and interior finishes (keeping in mind that these materials are all reclaimed and recycled) will also generate great savings so that affordable housing becomes much more viable.

There are also options to help businesses survive and be more successful. In particular, shops and businesses can support each other and build a profit-sharing business community similar to eco industrial parks (reference). Communities emphasizing common goals do not prioritize individual profits but put emphasis on communal gains and savings as well as on the sharing of responsibilities. 


\section{CONCLUSIONS}

Sustainable urban implants are a very comprehensive and constructive answer to the environmental problems that we face. They are the evidence that we can create better living conditions and an enjoyable lifestyle with little effort by putting the right elements of sustainable urban planning and architecture together. Thus, sustainable urban implants offer a lifestyle and not just energy savings. More importantly, they will provide well-being and comfort for humans now and into the future. Inner suburbs will gain urban spaces and residents will see that they can have and active and fulfilling lifestyle without driving downtown.

True urban implant developments, innovations directly related to energy efficiency and sustainability, will become important and experience will be gained with renewable energy technologies, sustainable design, sustainable urban planning and construction practices which will help to shift the conventional energy system to alternative sustainable systems over the years.

Technological research will also concentrate on more sustainable materials and more energy-efficient and environmentally-friendly production systems. Currently the cement industry is working hard to perfect a $\mathrm{CO}_{2}$-absorbing concrete that is being tested in the U.K.

Communities will also grow stronger and economies more stable through sustainable urban implants as they offer a new lifestyle and also create a base that is sustainable and healthy now and in the future.

\section{End of Thesis|Project report}

